Science on the DOI Landscape Initiative

Prepared in cooperation with the South Florida Water Management District

Evaluation of Effects of Changes in Canal Management and Precipitation Patterns on Salinity in Biscayne Bay, Florida, Using an Integrated Surface-Water/Groundwater Model

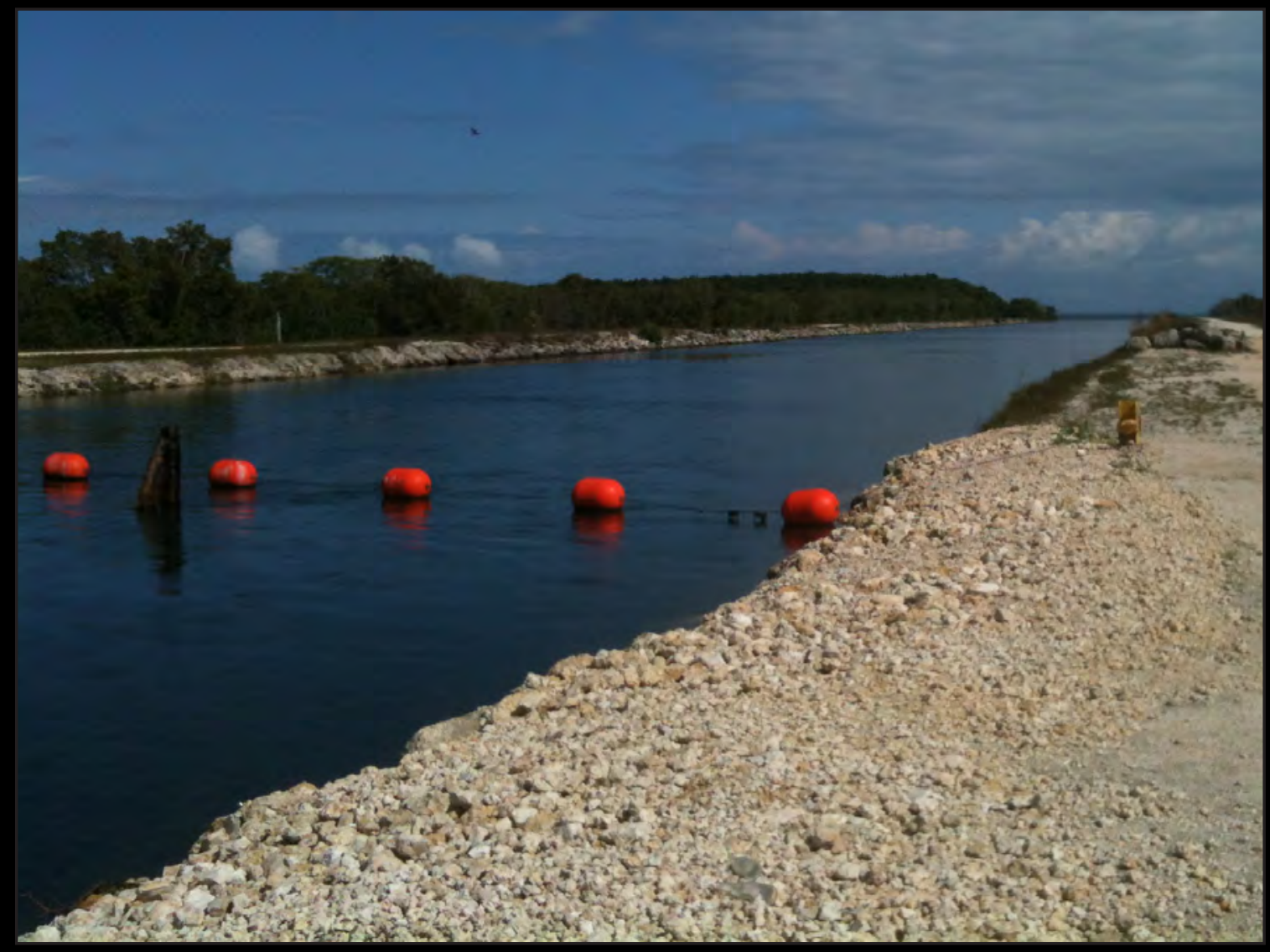

Scientific Investigations Report 2012-5099 
Cover. Mowry Canal downstream from structure S-20F looking east toward Biscayne Bay. Photograph by Joseph D. Hughes. 


\section{Evaluation of Effects of Changes in Canal Management and Precipitation Patterns on Salinity in Biscayne Bay, Florida, Using an Integrated Surface-Water/Groundwater Model}

By Melinda A. Lohmann, Eric D. Swain, John D. Wang, and Joann Dixon

Prepared in cooperation with the South Florida Water Management District

Science on the DOI Landscape Initiative

Scientific Investigations Report 2012-5099 


\section{U.S. Department of the Interior \\ KEN SALAZAR, Secretary \\ U.S. Geological Survey \\ Marcia K. McNutt, Director}

\section{U.S. Geological Survey, Reston, Virginia: 2012}

For more information on the USGS - the Federal source for science about the Earth, its natural and living resources, natural hazards, and the environment, visit http://www.usgs.gov or call 1-888-ASK-USGS.

For an overview of USGS information products, including maps, imagery, and publications, visit http://Www.usgs.gov/pubprod

To order this and other USGS information products, visit http://store.usgs.gov

Any use of trade, product, or firm names is for descriptive purposes only and does not imply endorsement by the U.S. Government.

Although this report is in the public domain, permission must be secured from the individual copyright owners to reproduce any copyrighted materials contained within this report.

Suggested citation:

Lohmann, M.A., Swain, E.D., Wang, J.D., and Dixon, Joann, 2012, Evaluation of effects of changes in canal management and precipitation patterns on salinity in Biscayne Bay, Florida, using an integrated surface-water/groundwater model: U.S. Geological Survey Scientific Investigations Report 2012-5099, 94 p. 


\section{Acknowledgments}

The authors would like to extend special thanks to Rick Alleman and Teresa Coley of the South Florida Water Management District, Sarah Bellmund of Biscayne National Park, and Virginia Walsh of the Miami-Dade Water and Sewer Department for their input and assistance in obtaining data for the study.

This report was funded by the Past and Future Impacts of Sea Level Rise on Coastal Habitats and Species (FISCHS) project as part of the U.S. Geological Survey (USGS) Priority Ecosystems Science Initiative. The authors would like to extend appreciation to USGS scientist Christian D. Langevin whose assistance was invaluable to the development of the model. Additionally, the authors would like to thank other USGS scientists, Linzy Brakefield and Kevin Cunningham, and Kevin Chartier, formerly of the USGS, for their contributions to the formation of the model. 



\section{Contents}

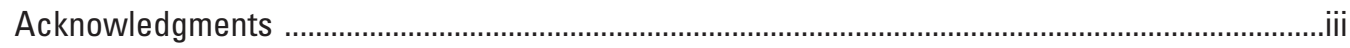

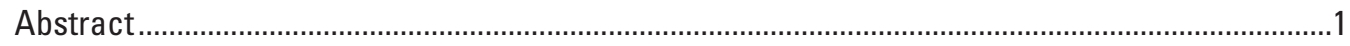

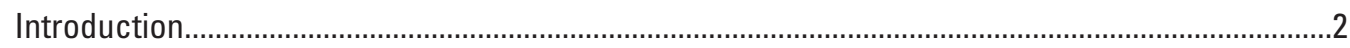

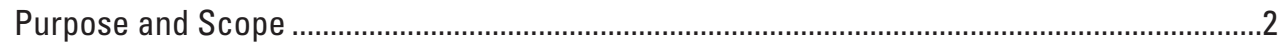

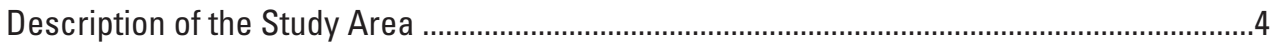

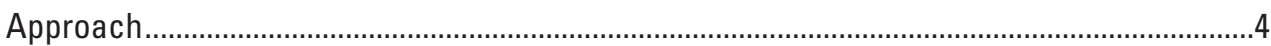

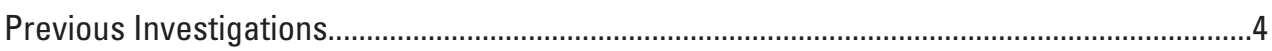

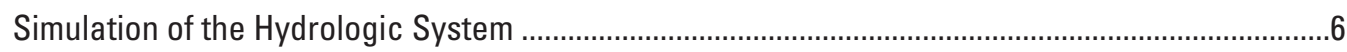

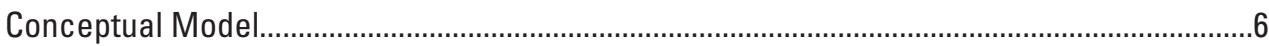

Numerical Model Construction ...............................................................................................

Spatial and Temporal Discretization ..............................................................................

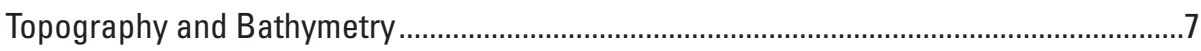

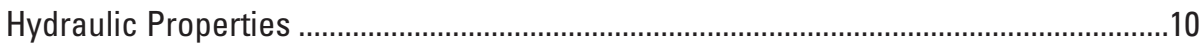

Aquifer Properties ............................................................................................ 10

Surface-Water Properties .......................................................................................... 10

Groundwater/Surface-Water Leakage Properties.................................................... 10

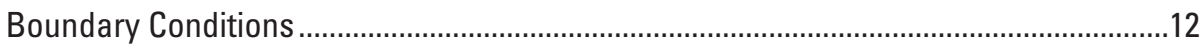

Groundwater Flux at Model Extent .................................................................. 12

Canal Boundaries ................................................................................................. 14

Upstream from Coastal Control Structures .......................................................14

Downstream from Coastal Control Structures..................................................15

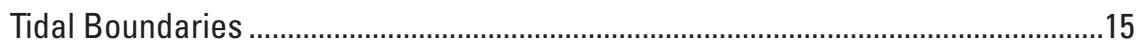

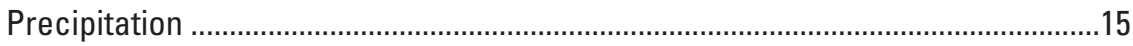

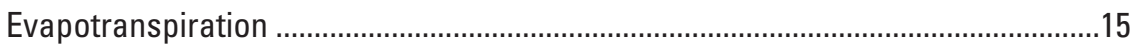

Wind-Blown Surface Water.......................................................................................... 18

Groundwater Pumpage ................................................................................... 18

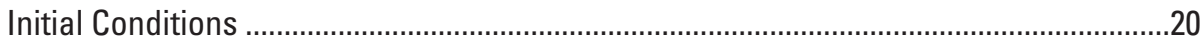

Simulation of the Hydrologic System and Model Fit ..................................................................20

Groundwater Heads ..................................................................................................20

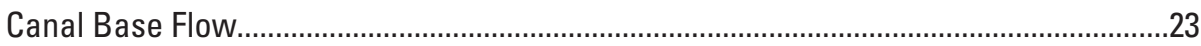

Saltwater-Freshwater Interface ......................................................................................27

Biscayne Bay Salinity and Temperature Measurements.................................................27

Quantification of Factors that Contribute to Biscayne Bay Salinity ..........................................38

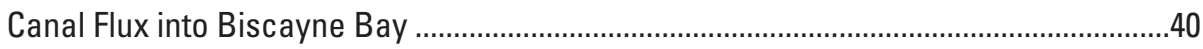

Groundwater Flux into Biscayne Bay ...........................................................................

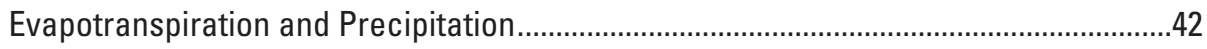

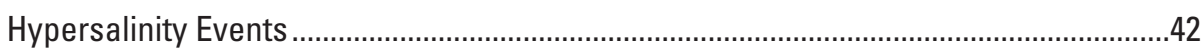

Sensitivity Testing ....................................................................................................................... 43

Effects of Sensitivity Tests on Simulated Groundwater Heads......................................46

Effects of Sensitivity Tests on Groundwater Discharge to Biscayne Bay........................48

Effects of Sensitivity Tests on Bay Salinity.......................................................................48

Effects of Changes in Canal Flux and Precipitation on Biscayne Bay Salinity................................48

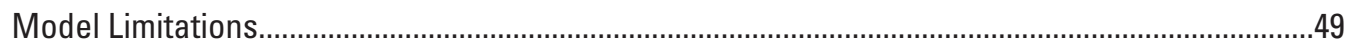




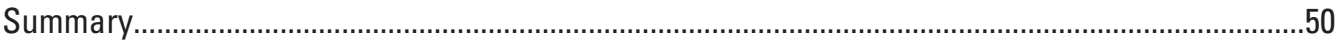

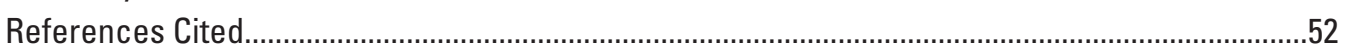

Appendix 1. FTLOADDS Version 3.3 Model Code Modifications from Previous Version..............58

Leakage Formulation ............................................................................................................58

Surface-Water Leakage with Multiple Groundwater Layers ................................................58

Maintaining Numerical Stability of Leakage Formulation........................................................59

Defining Surface-Water Sources, Rainfall, and Evapotranspiration .......................................60

Computing Evapotranspiration from Latent Heat ...................................................................61

Incorporation of Hydraulic Barriers ................................................................................62

Defining Input File Names and Locations ............................................................................62

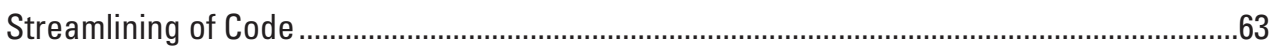

Code Modifications to Use Modules ..........................................................................................63

Appendix 2. Parameters for FTLOADDS Input Files......................................................................65

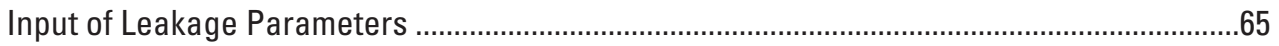

User Input of Surface-Water Inflows and Outflows ............................................................65

User Input of Rainfall Data .......................................................................................................66

User Input of Evapotranspiration Data ...............................................................................67

User Input of Hydraulic Barrier Data .....................................................................................68

Appendix 3. Groundwater Boundaries for Layers 1-20 Used in the Biscayne Bay Model..........69

Appendix 4. Temporal Data-Collection Stations Used in the Biscayne Bay Model ............................89

\section{Figures}

1. Map showing locations of the model area, coastal surface-water control structures, and municipal well fields in South Florida

2. Schematic showing relations of geologic formations, aquifers, and semiconfining units of the surficial aquifer system across central Miami-Dade County..........................5

3. Map showing the model grid and surface-water boundary conditions...........................8

4. Map showing the groundwater boundaries for layer 1 and locations of canals and control structures in the model area.

5. Map showing model topography and bathymetry ........................................................11

6. Map showing horizontal hydraulic conductivity of the Biscayne aquifer interpolated from point field data collected by Fish and Stewart (1991)...........................13

7. Map showing land-use distribution used to develop Manning's $n$ values.........................14

8. Map showing locations of wind, evapotranspiration, rainfall, and tidal data sites ........19

9. Graph showing daily total municipal pumpage applied to the model from well fields, 1996-2004

10. Map showing locations of groundwater monitoring stations and the average differences between model simulated and measured water levels, 1996-2004....

11. Graphs showing mean error, mean absolute error, and root mean squared error for all simulated groundwater heads for the 1996-2004 simulation period, shown daily, with daily average precipitation for all rainfall sites, and monthly.

12. Graphs showing simulated and measured daily water levels at selected groundwater monitoring sites

13. Map showing mean absolute error between simulated and observed base flow in designated drainage basins, 1996-2004 
14. Graphs showing simulated and measured daily canal base flow in designated drainage basins, 1996-2004 .

15. Graph showing total simulated salt mass in the Biscayne aquifer, 1996-2004 ...............29

16. Map showing simulated 2004 distribution of groundwater salinity at the base of the Biscayne aquifer, and the estimated extent of saltwater intrusion in 1995

17. Map showing location of salinity and temperature monitoring sites in Biscayne Bay.

18. Graphs showing simulated and vertically averaged surface-water salinity measured monthly in north, central, and south Biscayne Bay, and Barnes Sound, 1996-2004

19. Map showing simulated distribution of salinity in Biscayne Bay and inundated areas for dry season conditions in January of 1997 and 2004 and wet season conditions in June of 1997 and 2004.

20. Graphs showing simulated and vertically averaged surface-water temperature measured monthly in north, central, and south Biscayne Bay, 1996-2004

21. Maps showing simulated distribution of temperature in Biscayne Bay and inundated areas for dry season conditions in January of 1997 and 2004 and wet season conditions in June of 1997 and 2004

22. Graph showing simulated daily total and fresh groundwater discharge and measured daily canal discharge to Biscayne Bay, 1996-2004

23. Map showing distribution of simulated groundwater recharge and discharge in the model area, 1996-2004

24. Graph showing total and seasonal precipitation rates for the simulation period, 1996-2004

25. Graph showing the difference in mean error, at each observation station, between the base case and selected sensitivity test simulations.

26. Graphs showing response of salinity at site NIB in northern Biscayne Bay to simulated variations of evapotranspiration and leakage and flow and rainfall...............46

27. Graphs showing response of salinity at site BB50 in southern Biscayne Bay to simulated variations of evapotranspiration and leakage and flow and rainfall......

\section{Tables}

1. Aquifer property values used in model (from Langevin, 2001) .......................................12

2. Manning's n coefficients used in model .............................................................................12

3. Canal reaches and locations, river bottom elevations, and vertical conductance used to set model boundary conditions for canals upstream from the coastal control structures.

4. Coastal control structures for which discharge rates were applied as influx into the canal system

5. Tidal properties used to specify boundary conditions at the Atlantic Ocean model boundary

6. Mean error, mean absolute error, and root mean squared error for all groundwater observations for sensitivity test simulations, and percent difference total groundwater discharge and freshwater groundwater discharge between sensitivity test simulations and Base Case simulation.

7. Simulated water budget. Cumulative volumes of water in cubic meters for 9-year simulation period

8. Mean error for groundwater observations used for sensitivity test simulations ............44 


\section{Conversion Factors}

SI to Inch/Pound

\begin{tabular}{|c|c|c|}
\hline Multiply & By & To obtain \\
\hline \multicolumn{3}{|c|}{ Length } \\
\hline centimeter $(\mathrm{cm})$ & 0.3937 & inch (in.) \\
\hline meter $(\mathrm{m})$ & 3.281 & foot $(\mathrm{ft})$ \\
\hline kilometer (km) & 0.6214 & mile (mi) \\
\hline \multicolumn{3}{|c|}{ Area } \\
\hline square kilometer $\left(\mathrm{km}^{2}\right)$ & 0.3861 & square mile $\left(\mathrm{mi}^{2}\right)$ \\
\hline \multicolumn{3}{|c|}{ Volume } \\
\hline cubic meter $\left(\mathrm{m}^{3}\right)$ & 264.2 & gallon (gal) \\
\hline \multicolumn{3}{|c|}{ Velocity } \\
\hline meter per second $(\mathrm{m} / \mathrm{s})$ & 3.281 & foot per second $(\mathrm{ft} / \mathrm{s})$ \\
\hline \multicolumn{3}{|c|}{ Flow rate } \\
\hline cubic meter per day $\left(\mathrm{m}^{3} / \mathrm{d}\right)$ & 35.31 & cubic foot per day $\left(\mathrm{ft}^{3} / \mathrm{d}\right)$ \\
\hline liter per second $(\mathrm{L} / \mathrm{s})$ & 15.85 & gallon per minute (gal/min) \\
\hline cubic meter per day $\left(\mathrm{m}^{3} / \mathrm{d}\right)$ & 264.2 & gallon per day (gal/d) \\
\hline cubic meter per second $\left(\mathrm{m}^{3} / \mathrm{s}\right)$ & 22.83 & million gallons per day (Mgal/d) \\
\hline \multicolumn{3}{|c|}{ Precipitation rate } \\
\hline centimeter per year $(\mathrm{cm} / \mathrm{yr})$ & 0.3937 & inch per year (in/yr) \\
\hline \multicolumn{3}{|c|}{ Hydraulic conductivity } \\
\hline meter per day $(\mathrm{m} / \mathrm{d})$ & 3.281 & foot per day (ft/d) \\
\hline \multicolumn{3}{|c|}{ Transmissivity* } \\
\hline meter squared per day $\left(\mathrm{m}^{2} / \mathrm{d}\right)$ & 10.76 & foot squared per day $\left(\mathrm{ft}^{2} / \mathrm{d}\right)$ \\
\hline
\end{tabular}

Inch/Pound to SI

\begin{tabular}{lcl}
\hline \multicolumn{1}{c}{ Multiply } & By & To obtain \\
\hline & Length & \\
\hline foot $(\mathrm{ft})$ & 0.3048 & meter $(\mathrm{m})$ \\
\hline \multicolumn{3}{l}{ Flow rate } \\
\hline million gallons per day $(\mathrm{Mgal} / \mathrm{d})$ & 0.04381 & cubic meter per second $\left(\mathrm{m}^{3} / \mathrm{s}\right)$ \\
\hline & Hydraulic conductivity & \\
\hline foot per day $(\mathrm{ft} / \mathrm{d})$ & 0.3048 & meter per day $(\mathrm{m} / \mathrm{d})$ \\
\hline
\end{tabular}

Vertical coordinate information is referenced to the North American Vertical Datum of 1988 (NAVD 88), unless explicitly stated as "National Geodetic Vertical Datum of 1929 (NGVD 29)."

Horizontal coordinate information is referenced to the North American Datum of 1983 (NAD 83).

Elevation is the distance above the vertical datum.

*Transmissivity: The standard unit for transmissivity is cubic foot per day per square foot times foot of aquifer thickness [(ft $\left.\left.\mathrm{ft}^{3} \mathrm{~d}\right) / \mathrm{ft}^{2}\right] \mathrm{ft}$. In this report, the mathematically reduced form, foot squared per day $\left(\mathrm{ft}^{2} / \mathrm{d}\right)$, is used for convenience.

Specific conductance is given in microsiemens per centimeter at 25 degrees Celsius $\left(\mu \mathrm{S} / \mathrm{cm}\right.$ at $\left.25^{\circ} \mathrm{C}\right)$.

Concentrations of chemical constituents in water are given in milligrams per liter ( $\mathrm{mg} / \mathrm{L})$. 


\section{Abbreviations}

\begin{tabular}{|c|c|}
\hline BNP & Biscayne National Park \\
\hline CERP & Comprehensive Everglades Restoration Plan \\
\hline DERM & Department of Environmental Resources Management \\
\hline ENP & Everglades National Park \\
\hline ET & evapotranspiration \\
\hline FIU & Florida International University \\
\hline FTLOADDS & Flow and Transport in a Linked Overland/Aquifer Density Dependent System \\
\hline GIS & geographic information system \\
\hline LIDAR & Light Detection and Ranging \\
\hline MAE & mean absolute error \\
\hline ME & mean error \\
\hline MSL & mean sea level \\
\hline NGDC & National Geophysical Data Center \\
\hline NOAA & National Oceanic and Atmospheric Administration \\
\hline PET & potential evapotranspiration \\
\hline PSU & practical salinity unit \\
\hline RMSE & root mean square error \\
\hline SEAWAT & $\begin{array}{l}\text { Computer program for simulation of three-dimensional variable-density } \\
\text { groundwater flow }\end{array}$ \\
\hline SERC & Southeast Environmental Research Center \\
\hline SFWMD & South Florida Water Management District \\
\hline SFWMM & South Florida Water Management Model \\
\hline SWIFT2D & Surface-Water Integrated Flow and Transport in Two Dimension \\
\hline TIME & Tides and Inflows in the Mangroves of the Everglades \\
\hline TIN & Triangular Irregular Network \\
\hline USACOE & U.S. Army Corps of Engineers \\
\hline USGS & U.S. Geological Survey \\
\hline UTM & Universal Transverse Mercator \\
\hline WOMN & Water Quality Monitoring Network \\
\hline
\end{tabular}





\title{
Evaluation of Effects of Changes in Canal Management and Precipitation Patterns on Salinity in Biscayne Bay, Florida, Using an Integrated Surface-Water/Groundwater Model
}

\author{
By Melinda A. Lohmann', Eric D. Swain', John D. Wang' ${ }^{2}$ and Joann Dixon'
}

\section{Abstract}

Biscayne National Park, located in Biscayne Bay in southeast Florida, is one of the largest marine parks in the country and sustains a large natural marine fishery where numerous threatened and endangered species reproduce. In recent years, the bay has experienced hypersaline conditions (salinity greater than 35 practical salinity units) of increasing magnitude and duration. Hypersalinity events were particularly pronounced during April to August 2004 in nearshore areas along the southern and middle parts of the bay. Prolonged hypersaline conditions can cause degradation of water quality and permanent damage to, or loss of, brackish nursery habitats for multiple species of fish and crustaceans as well as damage to certain types of seagrasses that are not tolerant of extreme changes in salinity.

To evaluate the factors that contribute to hypersalinity events and to test the effects of possible changes in precipitation patterns and canal flows into Biscayne Bay on salinity in the bay, the U.S. Geological Survey constructed a coupled surface-water/groundwater numerical flow model. The model is designed to account for freshwater flows into Biscayne Bay through the canal system, leakage of salty bay water into the underlying Biscayne aquifer, discharge of fresh and salty groundwater from the Biscayne aquifer into the bay, direct effects of precipitation on bay salinity, indirect effects of precipitation on recharge to the Biscayne aquifer, direct effects of evapotranspiration (ET) on bay salinity, indirect effects of ET on recharge to the Biscayne aquifer, and maintenance of mass balance of both water and solute.

The model was constructed using the Flow and Transport in a Linked Overland/Aquifer Density Dependent System (FTLOADDS) simulator, version 3.3, which couples the twodimensional, surface-water flow and solute-transport simulator SWIFT2D with the density-dependent, groundwater flow and solute-transport simulator SEAWAT. The model was calibrated

${ }^{1}$ U.S. Geological Survey.

${ }^{2}$ University of Miami (retired). by a trial-and-error method to fit observed groundwater heads, estimated base flow, and measured bay salinity and temperatures from 1996 to 2004, as well as the location of the freshwater-saltwater interface in the aquifer, by adjusting ET rate limiters, canal vertical hydraulic conductance, leakage rate coefficients (transition-layer thickness and hydraulic conductivity), Manning's $n$ value, and delineation of rainfall zones.

Although flow budget calculations indicate that precipitation, ET, and groundwater flux into the bay represent a small portion of the overall budget, these factors may be important in controlling salinity in some parts of the bay, for example the southern parts of the bay where the canal system is not extensively developed or controlled. The balance of precipitation and ET during the wet season generally results in a reduction of bay salinity, whereas the balance of precipitation and ET during the dry season generally results in an increase in bay salinity. During years when wet season precipitation is lower than average, for example less than 70 percent total precipitation for an average year, ET could outweigh precip-itation over the bay for essentially the entire year.

Hypersaline conditions are prone to occur near the end of the dry season because precipitation rates are generally lower, canal discharge rates (which are strongly correlated to precipitation rates) are also generally lower, and ET rates are higher than during the rest of the year. The hypersalinity event of 2004 followed several years of relatively low precipitation and correspondingly reduced canal structure releases and was unusually extensive, continuing into July. Thus, hypersalinity is ultimately the result of a cumulative deficit of precipitation.

The model was used to test the effects of possible changes in canal flux and precipitation. Simulation results showed that by increasing, reducing, or modifying canal discharge rates, the effects on salinity in the bay were more pronounced in the northern part of the bay where there are more canals and canal-control structures. By doubling and halving precipitation, the effects on bay salinity were more pronounced in the southern part of the bay than in the northern part of the bay where there are fewer canals and canalcontrol structures. 
The model is designed to quantify factors that contribute to hypersaline conditions in Biscayne Bay and may be less appropriate for addressing other issues or examining conditions substantially different from those described in this report. Model results must be interpreted in light of model limitations, which include representation of the system and conceptual model, uncertainty in physical properties used to describe the system or processes, the scale and discretization of the system, and representation of the boundary conditions.

\section{Introduction}

Biscayne National Park (BNP), located off the southeast coast of Florida, is one of the largest marine parks in the country and contains four distinct environmental areas: Biscayne Bay, the northern islands of the Florida keys, a mangrove forest, and a coral reef. The BNP provides a large natural marine fishery where numerous threatened and endangered species reproduce and is part of the only living coral bank barrier reef in North America. In recent years, however, the BNP has experienced episodic hypersalinity events (salinity greater than 35 practical salinity units (psu)), particularly in the nearshore areas of Biscayne Bay. Continued hypersaline conditions could cause permanent damage to, or loss of, brackish nursery habitats in the transition zone between the terrestrial and marine environments. Possible contributing factors to the hypersalinity events include reduced discharge of fresh canal water into the bay, lower than normal precipitation, increased evapotranspiration (ET), reduced discharge of fresh groundwater into the bay, or increased discharge of salty groundwater into the bay. Historical analyses of Biscayne Bay core samples show no apparent hypersaline events prior to the 1900s (Ishman and others, 1998; Wingard and others, 2003, 2004), indicating the possibility that anthropogenic alterations to the hydrologic system may have substantial influence on salinity in Biscayne Bay.

The Comprehensive Everglades Restoration Plan (CERP), authorized in 2000, proposes several different restoration scenarios for South Florida all of which are designed to modify freshwater deliveries through the existing canal system. In order to evaluate the possible effects of these restoration activities on salinity in Biscayne Bay, as well as other contributing factors, the U.S. Geological Survey (USGS), in cooperation with the South Florida Water Management District (SFWMD) as part of the Science on the DOI Landscape Initiative, began a study in 2006 to investigate the effects of natural processes and anthropogenic activities on Biscayne Bay salinity, identify the factors controlling hypersalinity events, and evaluate the possible effects of changes in canal management on Biscayne Bay salinity. To evaluate the factors that affect salinity in Biscayne Bay, a numerical model was developed that accounts for precipitation, ET, freshwater discharge from the canal system, and fresh and salty groundwater discharge, as well as the mass balanced exchange of water and dissolved solute between the groundwater and surface-water systems. Scenarios representing a range of canal-flow conditions and precipitation distributions were simulated. Results of the study may be used by water-resource managers to balance competing demands on the canal system.

\section{Purpose and Scope}

The purpose of this report is to evaluate the factors that contribute to hypersalinity events and test the effects of possible changes in precipitation patterns and canal flows into Biscayne Bay on salinity in the bay. In particular, this report examines potential factors contributing to hypersalinity events observed in recent years, specifically during one of the largest and extended periods of hypersalinity on record in the nearshore areas of Biscayne Bay, April to August 2004. To account for the hydrogeological and climatic factors that affect Biscayne Bay salinity, the study area was delineated to include Biscayne Bay and surrounding areas from the Broward County/MiamiDade County boundary south into Barnes Sound, and from the eastern boundary of the Everglades National Park (ENP) eastward to the BNP/Atlantic Ocean boundary (fig. 1). The study period is from January 1996 to December 2004 and includes periods of normal salinity distribution and hypersalinity in Biscayne Bay. The report documents the coupled surface-water/ groundwater flow and solute-transport numerical model used to examine the processes that control Biscayne Bay salinity as well as changes made to the Flow and Transport in a Linked Overland/Aquifer Density Dependent System (FTLOADDS) simulator used to simulate the hydrologic system. The model accounts for controlled flows of fresh canal water into Biscayne Bay, leakage of salty bay water into the underlying Biscayne aquifer, discharge of fresh and salty groundwater from the Biscayne aquifer into the bay, direct effects of precipitation on bay salinity, indirect effects of precipitation on recharge to the Biscayne aquifer, direct effects of ET on bay salinity, indirect effects of ET on recharge to the Biscayne aquifer, and maintenance of mass balance of both water and solute.

The model is based on a previous groundwater flow and solute-transport model designed to investigate groundwater flux into Biscayne Bay (Langevin, 2001) and extends the work by specifically simulating salinity distribution in the bay and by accounting for additional specific processes that likely contribute to Biscayne Bay salinity. Discussions in this report include a description of the modeling approach, including refinements made to the FTLOADDS simulator, conceptual model, numerical model construction, input data sources, calibration approach, calibrated model results and model-fit characteristics, and sensitivity of the model to input parameters within expected ranges of uncertainty. Calibrated model results are discussed in terms of effects of simulated processes on Biscayne Bay salinity, and scenario results representing a range of possible canal flow and precipitation conditions are presented. Limitations of the model are presented to guide the interpretation of model results. 


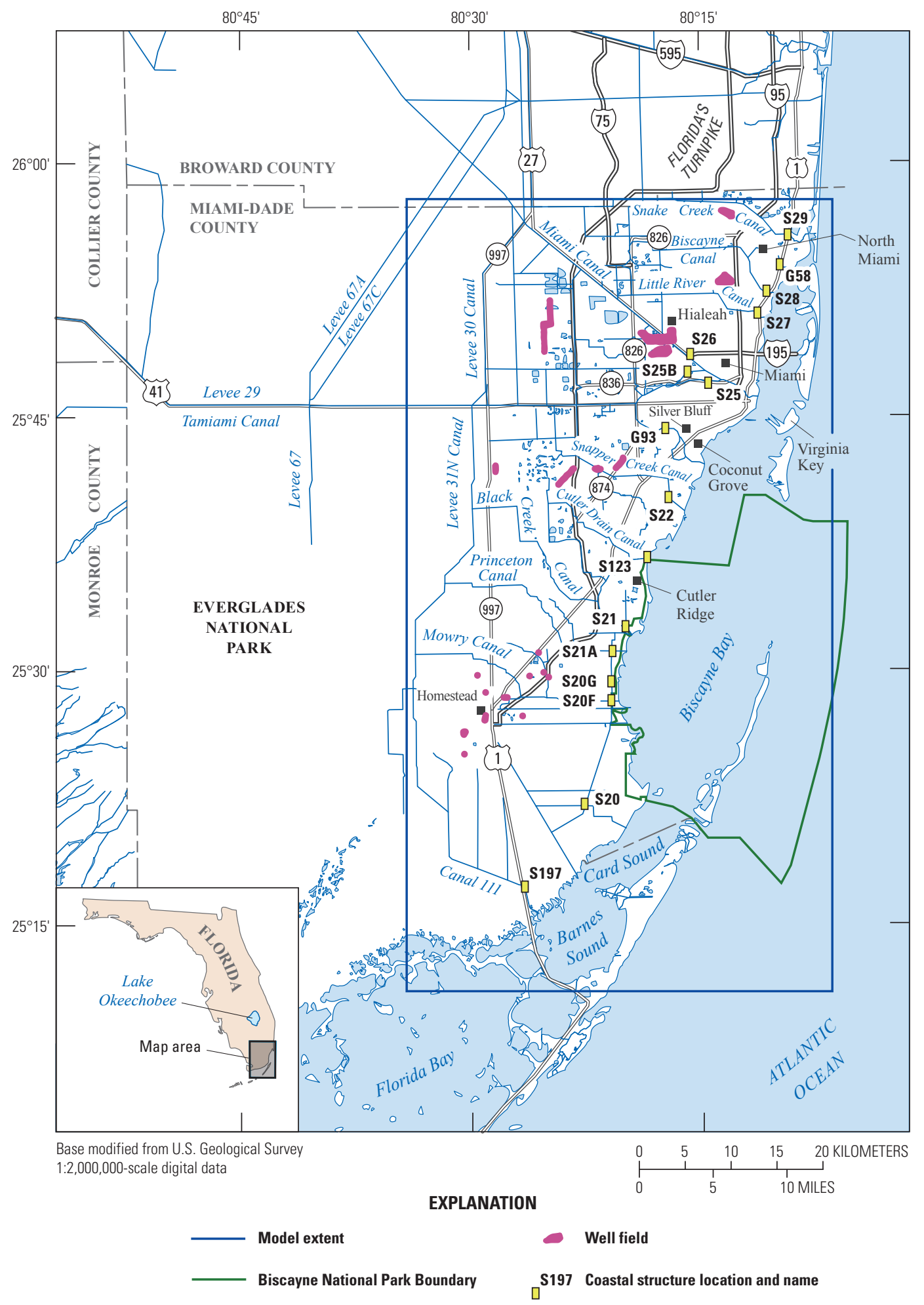

Figure 1. Locations of the model area, coastal surface-water control structures, and municipal well fields in South Florida. 


\section{Description of the Study Area}

The study area comprises most of the urban areas of Miami-Dade County (fig. 1). The model domain is bordered to the north by the Broward/Miami-Dade County line along the Snake Creek Canal, then extends southward into northeastern Florida Bay, Barnes Sound, and the Atlantic Ocean. The eastern limits of the area are located just off the barrier coral reefs that surround Biscayne Bay to the Atlantic Ocean. The study area is bordered to the west by the L-31/C-111 canal system located along the eastern boundary of the ENP. Land use in the study area is largely urban, with some agricultural areas, wetlands, and the marine recreational area of Biscayne National Park.

The hydrology of the area is characterized by the dynamic interactions between the surface water and groundwater. The surface-water system is regulated by an extensive network of canals used for flood control purposes and for agricultural irrigation. The system includes a network of salinity control structures, located along the coastline, used to prevent saltwater intrusion in both the surface-water and ground-water systems. The canals, which were originally constructed for drainage purposes, were placed in historically low areas that previously routed overland flow of freshwater from the Everglades to Biscayne Bay. As the freshwater flow from the Everglades was reduced (or altogether eliminated), only small conduits of coastal wetlands remained to channel relatively small volumes of natural runoff to the bay. This flow was replaced by freshwater discharges through the canal system, which channelized and modified the timing and distribution of the flows altering the water quality in nearshore areas.

The groundwater flow system is composed of a shallow surficial aquifer system, most of which comprises the Biscayne aquifer and the underlying confined Floridan aquifer system. The surficial and Floridan aquifer systems are separated by alternating beds of sand, silt, and clay that collectively restrict the movement of groundwater between the two aquifer systems. The model developed for this study simulates flow only in the Biscayne aquifer because it provides the primary source of groundwater discharge to Biscayne Bay (Parker and others, 1955; Kohout, 1960b; Langevin, 2001). Fish (1988), Fish and Stewart (1991), and Reese and Cunningham (2000) provide detailed descriptions of the hydrogeology and aquifer properties of the Biscayne aquifer and surficial aquifer system and comprising formations. A schematic diagram showing the relations between the lithostratigraphic and hydrogeologic units included in this study is depicted in figure 2 .

\section{Approach}

A numerical model was developed that simulates flow of freshwater through the canals and into the bay, groundwater flow within the Biscayne aquifer, exchange of fresh and saline water between the aquifer and the bay, freshwater recharge of the aquifer, and ET processes within the bay to evaluate the factors that control salinity in Biscayne Bay and the possible effects of changes in canal management or weather patterns. The model was developed using the FTLOADDS simulator (Langevin and others, 2005; Wang and others, 2007; Swain and Decker, 2009), which accounts for mass balanced flow and solute transport within and between the surface-water and groundwater systems. FTLOADDS is a simulator that couples the two-dimensional, surface-water flow and solute-transport simulator SWIFT2D (Leendertse, 1987; Schaffranek, 2004; Swain, 2005), with the density-dependent, groundwater flow and solute-transport simulator SEAWAT (Guo and Langevin, 2002). SEAWAT links the widely applied USGS MODFLOW code (McDonald and Harbaugh, 1988) with the solutetransport code MT3D (Zheng, 1990). FTLOADDS was modified for this study by including the calculation of heat transport, a revised formulation for the exchange between surface water and groundwater in multiple aquifer layers (this exchange was previously limited to the top aquifer layer), and a modification of the solar radiation term in the ET calculation to include albedo (appendix 1).

Model design and input were modified from a previously existing model that simulated groundwater discharge from the Biscayne aquifer into Biscayne Bay (Langevin, 2001). Additional data were used to constrain explicitly solved surface-water flow rates and controls on ET. The model was calibrated to daily groundwater levels in the Biscayne aquifer, estimated base flows (groundwater discharge to and recharge from canals), monthly Biscayne Bay salinity and temperature data, and qualitatively to the general location of the saltwaterfreshwater interface in the Biscayne aquifer. Scenarios representing an overall increase, decrease, and temporal averaging of canal fluxes into the bay were simulated. Scenarios representing an overall increase and decrease in precipitation were also simulated.

\section{Previous Investigations}

Over the past 60 years a variety of research has provided information about the hydrologic system in south Florida and the ecology and aquatic environment of Biscayne Bay. These studies provide insight regarding the processes that control salinity in the bay, as well as specific data that allow a quantitative description of the system. Information from these studies was used directly and indirectly to construct the numerical model documented herein and interpret the results.

The relevance of Biscayne Bay as a natural resource and the effects of salinity on this resource were presented by the Biscayne Bay Partnership Initiative (2001) and Thorhaug and others (1976), and include discussions of social and economic, management, regulation, and scientific issues. More specifically, salinity plays a major role in habitat type and suitability, and species survival rates for many of the different species of flora and fauna that reside within Biscayne Bay. Seagrass and macroalgae, which provide critical nursery habitat for pink shrimp and other fish communities, oysters, blue crabs, 


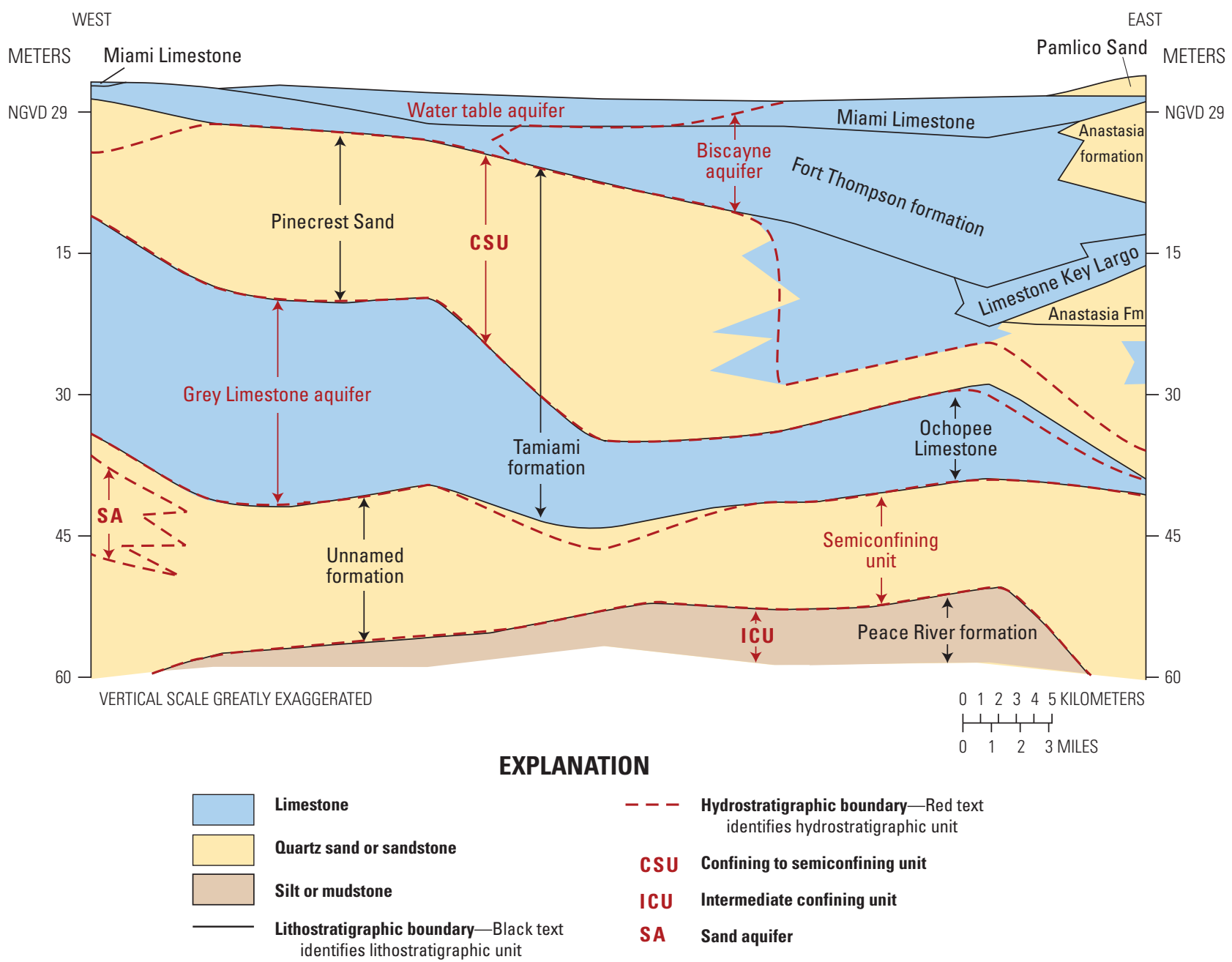

Figure 2. Relations of geologic formations, aquifers, and semiconfining units of the surficial aquifer system across central Miami-Dade County (from Langevin, 2001; modified from Reese and Cunningham, 2000).

manatees, and crocodiles, can show signs of stress or die-off during periods of high salinity (Mazzotti and Dunson, 1984; Lorenz, 1997; Serafy and others, 1997; Ross and others, 2000; Browder and others, 2002; Lirman and Cropper, 2003; Browder and others, 2005; Bachman and Rand, 2008; Lirman and others, 2008; Browder and Robblee, 2009; Madden and others, 2009; and Serrano and others, 2010). Analysis of sediment cores from central and southern Biscayne Bay indicates increasing salinity over the last century (Wingard and others, 2003, 2004).

As a result of concerns about increasing bay salinity and its effects on local ecosystems, BNP started regular monitoring of bay salinity and temperature, and published information about its monitoring network and reported observed salinity values (Bellmund and others, 2007). Other projects have involved using the data to help identify the sources of hypersalinity and prepare plans to help mitigate it in the future. Luo and Serafy (2003) collected salinity data in the bay near canal mouths and canal flows through water control structures and performed a statistical analysis to examine the relation between bay salinity and canal discharges to the bay during 1990-2002. One important result of their study was that the salinity regime in the bay near the discharge area of the canals could be affected for up to 15 days after a discharge event. Bellmund and others (2008) presented data on salinity in Biscayne Bay and concluded that the salinity in the bay could be explained to a large extent by changes in canal discharge volumes. Using data collected from the water-quality network in Biscayne Bay, Boyer (2004) hypothesized that the 2004 hypersaline event instead could have been caused by large tidal forces that created shorter residence times within the main body of the bay. More recently, however, the Biscayne Bay Coastal Wetlands Plan (U.S. Army Corps of Engineers, 2010) presented ways to help restore natural salinity patterns to the bay on the basis of the hypothesis that hypersaline events are related to canal discharges. 
Numerical models have been used to address a variety of aspects of the hydrologic system because they provide a way to quantify a complex system. Groundwater models have been constructed for southern Miami-Dade County to estimate groundwater discharges to Biscayne Bay and simulate salinity transport in Miami-Dade County and surrounding areas (Merritt, 1996, 1997; Langevin, 2001). An example of a surface-water model developed for South Florida is the Southern Inland and Coastal Systems (SICS) model (Swain and others, 2004; Wolfert and others, 2004), which simulated surface-water flow and salinity transport in the southern part of the Everglades and estimated freshwater flows to Florida Bay. Offshore surface-water models have been developed by the U.S. Army Corp of Engineers (Brown and others, 2003) to study the hydrodynamics and salinity in the bay, and by Wang and others (2003) to examine salinity, currents, and residence and their effect on larval transport in Biscayne Bay.

Because of the strong coupling between surface-water and groundwater systems in South Florida, several numerical models have been designed to explicitly account for both components of the hydrologic system and their interactions. The South Florida Water Management Model (SFWMM) (MacVicar and others, 1984) is a regional model that simulates the hydrologic response to canal structure operations. The model area extends from just north of Lake Okeechobee to the southern coastline of the ENP. Developed by Lin and others (2000), FEMWATER 123 is a finite-element model that can be used to simulate one-dimensional (1D) canal flow, 2D overland flow, and 3D groundwater flow, and explicitly accounts for canal operations. A coupled surface-water/groundwater model that accounts for canal and wetland flows in southern Miami-Dade County using the MODBRANCH code was developed by Swain and others (1996). The Tides and Inflows in the Mangroves of the Everglades (TIME) model was used with the FTLOADDS simulator to calculate freshwater flows to the coast (Wang and others, 2007). Like the version of the FTLOADDS simulator documented in the current report, the version used for the TIME model accounts for variable-density salinity transport, but does not include the surface-water heat transport formulation.

The model documented in the current report was developed using the hydrogeologic framework, parameter estimates, and other datasets from the variable-density groundwater model of Langevin (2001). The conceptual model for groundwater hydrology in South Florida draws largely on saltwater intrusion studies by Parker $(1945,1951)$, as well as Kohout (1960a, 1960b, 1961a, 1961b, 1964), Kohout and Hoy (1963), Kohout and Klein (1967), and Kohout and Kolipinski (1967). Fish and Stewart (1991) provided hydraulic data for the Biscayne aquifer in Miami-Dade County, including transport parameters necessary to simulate saltwater intrusion. Data required to simulate ET were provided by German (2000). The estimated location of the freshwater/saltwater interface used for calibration was from Sonenshein (1997), and data used for the calculation of initial salinity conditions were from Fitterman and others (1999). Salinity and temperature data in
Biscayne Bay used for model calibration were collected by Boyer (2004) and by the Florida Department of Environmental Resources Management (DERM) available through the SFWMD DBHYDRO database (South Florida Water Management District, 2006). Additional studies performed in the area are referenced in Langevin (2001).

\section{Simulation of the Hydrologic System}

A numerical model was constructed to represent those features of the hydrologic system that are likely to control salinity in Biscayne Bay. The model was constructed using the FTLOADDS simulator, which simulates the hydrologic flow and interactions between the Biscayne aquifer and the overlying surface-water flow system, including canals, wetlands, and highly developed urban areas. The model was developed using a groundwater flow model of Biscayne Bay and the surrounding area as its basis (Langevin, 2001). The model was calibrated to daily groundwater levels, estimated daily base flow, monthly Biscayne Bay salinity and temperature data, and the location of the saltwater-freshwater interface in the Biscayne aquifer. ET, leakage between the surface-water and groundwater systems, conductance of the canal beds, and aquifer hydraulic conductivity were used to test model sensitivity to parameter uncertainty. The model was then used to investigate the effects on Biscayne Bay salinity as a result of changes in canal inflow into Biscayne Bay and changes in precipitation.

\section{Conceptual Model}

Biscayne Bay salinity is controlled by the balance of freshwater and saltwater inflows and outflows to the bay. Biscayne Bay is a barrier-island lagoon, partially protected by barrier islands to the east from a practically unlimited source of Atlantic Ocean seawater. During predevelopment, freshwater entered the bay largely during the wet season (defined here as May-October) by overland flow, natural creeks, and sub-marine discharge from the Biscayne aquifer from the west, thus diluting the bay. Since predevelopment and the construction of the canal system, freshwater enters the bay through canals, primarily during the wet season when the canal structures release water for flood control purposes. During the dry season (November-April), canal releases are minimized to control saltwater intrusion and maintain Biscayne aquifer heads. Submarine discharge of fresh groundwater is difficult to measure. It is reported anecdotally that freshwater boils, areas where water flows upward to the surface of the bay from the ground, historically provided drinking water to sailors on ships in the bay (Munroe and Gilpin, 1985). In addition to groundwater discharge of freshwater, the Biscayne aquifer may discharge salty water into the bay, as seawater has intruded the aquifer as much as 10 kilometers $(\mathrm{km})$ inland in some locations in Miami-Dade County (Sonenshein, 1997). Direct precipitation onto the bay also reduces salinity as well as contributes 
to recharge of the Biscayne aquifer onshore. ET processes remove freshwater from the bay, resulting in increased salinity as well as reducing freshwater recharge to the Biscayne aquifer onshore. These combined processes (rainfall, canal discharges, submarine groundwater discharge, and ET) result in a strong seasonal salinity fluctuation in the bay with higher salinity generally occurring during the dry season and lower salinity occurring during the wet season. A preliminary data analysis indicates that discharges from the canal system and precipitation likely have a greater effect on Bay salinity than any of the other factors (Wolfert and others, 2007).

\section{Numerical Model Construction}

The FTLOADDS simulator was used to account for hydrologic flow within and between the Biscayne aquifer and the overlying surface-water system, including canals, wetlands, and highly developed urban areas. The groundwater component of the model was based on a previously developed groundwater model of the Biscayne aquifer in Miami-Dade County, constructed using the SEAWAT simulator (Guo and Langevin, 2002), and was designed to estimate groundwater fluxes into the bay (Langevin, 2001). For the groundwater component of the FTLOADDS model described in this report, values and distribution of aquifer hydraulic conductivity, storage, and porosity, as wells as canal bed conductivity, were taken directly from the SEAWAT model. The FTLOADDS model documented in this report uses a different model grid extent and orientation, different model cell size, and a modified topography than that used in Langevin (2001).

FTLOADDS explicitly solves for flow and solute transport in the surface-water system and the mass balanced flow of water and solute between the surface-water and groundwater systems. The version of FTLOADDS documented in this report has been updated from previous versions (Langevin and others, 2005; Wang and others, 2007; Swain and Decker, 2009) and includes (1) the calculation of heat transport, (2) a leakage formulation that allows for the exchange of surface water and groundwater to occur in variable layers of the groundwater component of the model (FTLOADDS previously limited exchange with the top layer of the groundwater model), and (3) a modification of the ET calculation by including albedo in the solar radiation term. These code modifications and model input instructions for the FTLOADDS simulator are described in appendixes 1 and 2.

\section{Spatial and Temporal Discretization}

The groundwater and surface-water components of the model share the same discretization in map view, 93 columns and 173 rows of uniformly sized model cells (500 meters (m) on a side; fig. 3), but input data assignment and use are different. These 16,089 cells cover an area of 4,022 square kilometers $\left(\mathrm{km}^{2}\right)$. The groundwater component of the model assigns input data at and computes flux between the cell centroids, while the surface-water component of the model assigns input data at and computes flux between the vertices of adjacent cells.

The groundwater component of the model is discretized vertically into 20 layers (appendix 3) within the Biscayne aquifer, comprising 145,202 active cells. The top elevation of the top layer of cells is defined by the land-surface elevation at the centroid of each cell. The bottom elevation of the top layer of cells is arbitrarily set at $-4 \mathrm{~m}$. The thickness of this layer varies from 4 to $11 \mathrm{~m}$, based on the variations in landsurface topography. Layer 2 is $1.5 \mathrm{~m}$ thick. Layers $3-20$ have uniform thicknesses of $2.75 \mathrm{~m}$, such that the bottom of the simulated system is at $-55 \mathrm{~m}$ (NAVD 88). Inactive cells are assigned below the base and at the lateral extent (layers 5-20; appendix 3) of the Biscayne aquifer as represented by Fish and Stewart (1991), assuming minimal flow into the aquifer from the underlying Pinecrest Sand, the semiconfining unit located below the Biscayne aquifer (fig. 2). Layers 1-4 (appendix 3) have a lateral extent that is bounded to the north, south, and west by the locations of the C-9, L-31N, and C-111 canals (fig. 4), and to the east by an ocean boundary. (If the Biscayne aquifer is still present in any of these areas in layers 5-20, these boundaries apply to those layers as well; appendix 3.) Additionally in layers 1 (fig. 4) and 2, cells are determined to be inactive in the Biscayne Bay area based on the depth of the bay.

The model calculates groundwater flow and solute transport, and surface-water flow and solute transport independently, and solutions to each set of equations require different temporal discretization. The simulation period is January 1996 through December 2004. Groundwater flow is calculated using daily time steps (3,288 stress periods). Groundwater solute-transport time steps were determined dynamically on the basis of the longest time step required for convergence of the transport equation and ranged from seconds to 1 day. A fixed, 10-minute time step was used for the surface-water component of the model to account for the rapidly changing hydrodynamic factors within the surface-water flow and transport solutions.

\section{Topography and Bathymetry}

Topographic data were obtained from the ENP (1-foot (ft) contours), the National Oceanic and Atmospheric Administration (NOAA) National Geophysical Data Center (NGDC) Coastal Relief Model dataset (land elevations and bathymetry; http://www.ngdc.noaa.gov/mgg/coastal/crm.html, accessed in June 2006) and from the U.S. Army Corps of Engineers Light Detection and Ranging (LIDAR) data system. These data were converted to meters (if not already in metric form) and used to create Triangular Irregular Network (TIN) surfaces. Elevation values were assigned to the model grid vertices and centroids to create single, integrated data by sampling the appropriate TIN as determined by the following criteria: if a vertex was located over water, elevation was assigned to the vertex from the NOAA dataset; if a vertex was located over land, elevation 


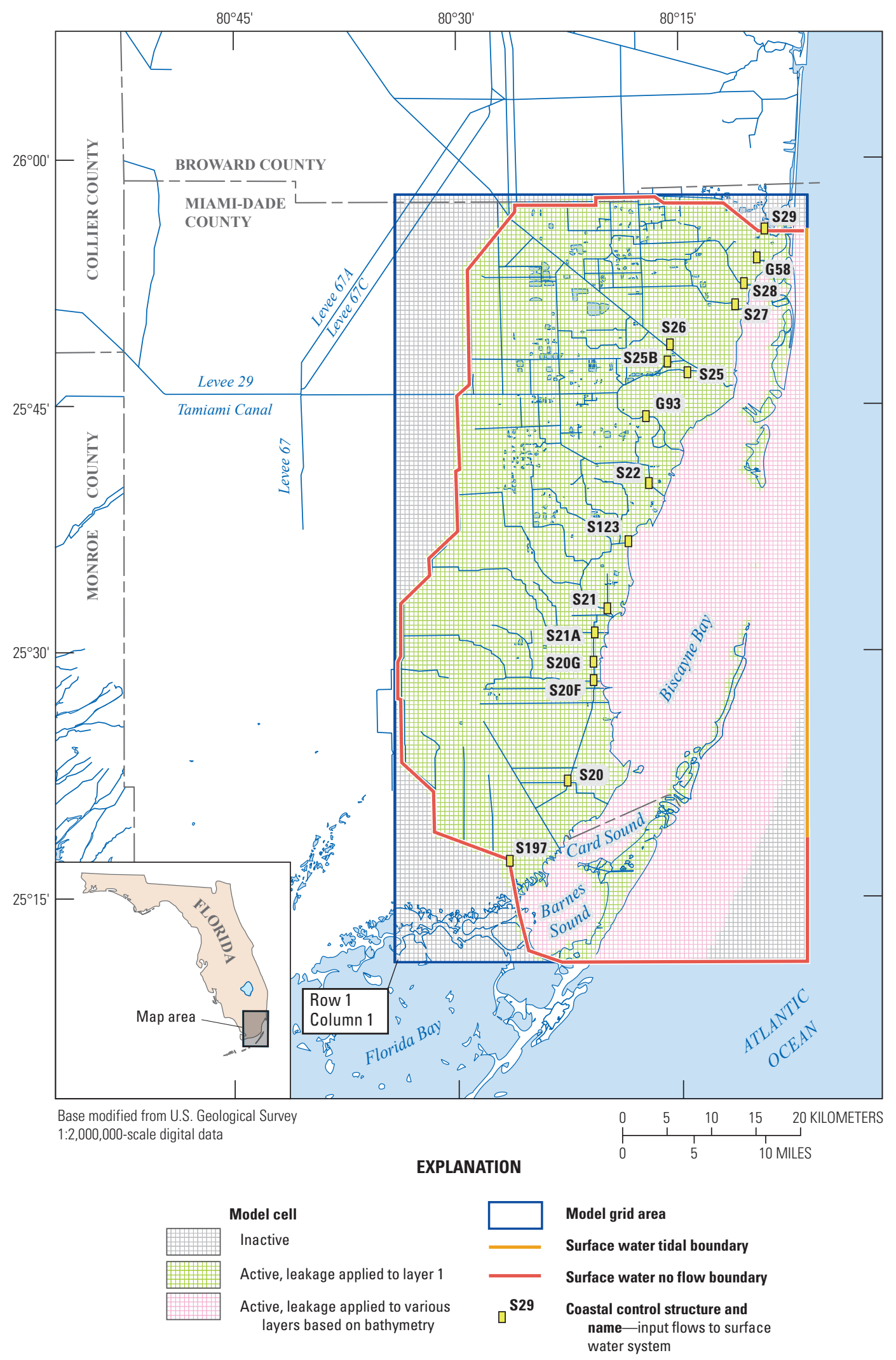

Figure 3. Model grid and surface-water boundary conditions. 


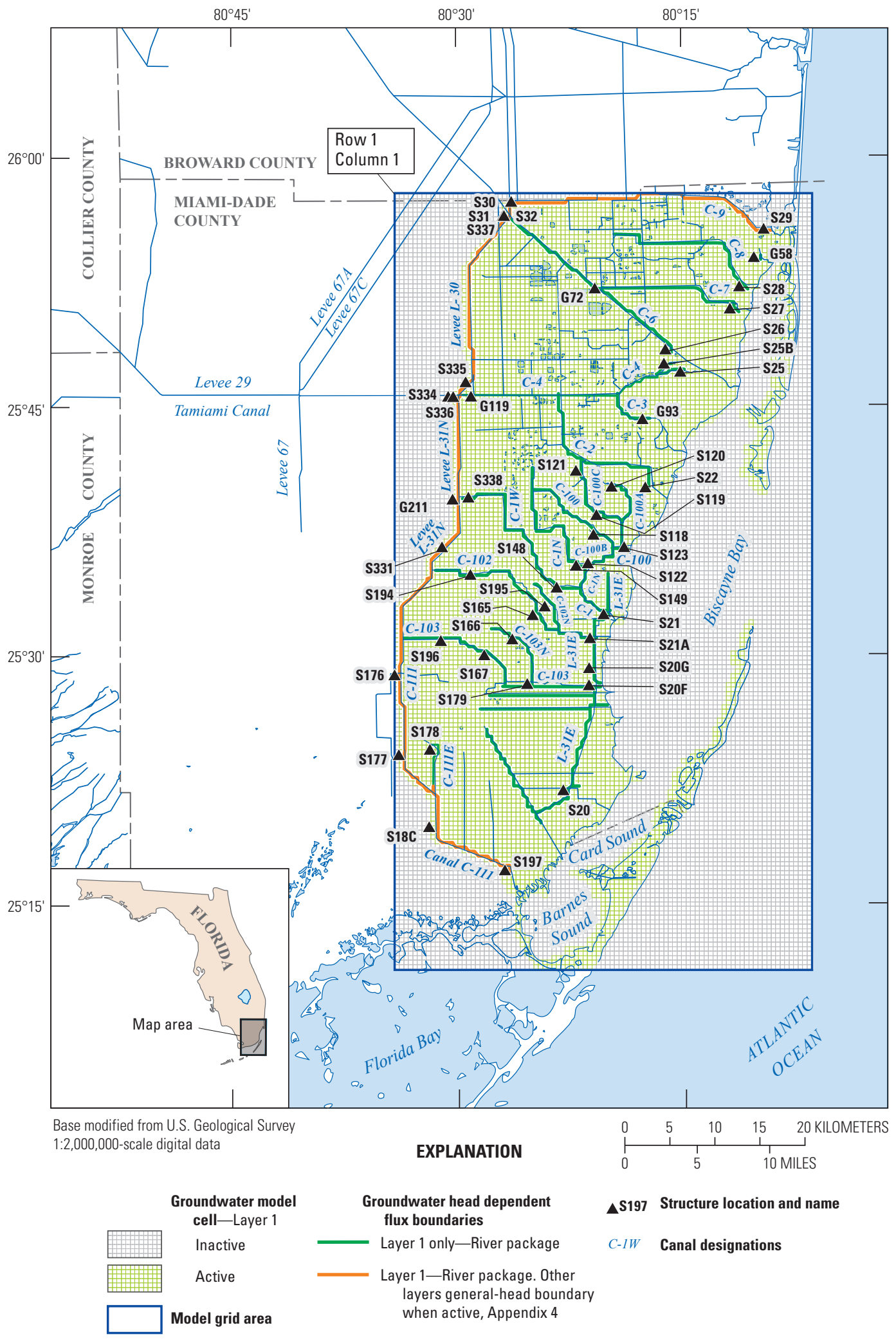

Figure 4. Groundwater boundaries for layer 1 and locations of canals and control structures in the model area. 
was assigned to the vertex from ENP maps; if greater than 50 percent of a cell area was over water, the elevation was assigned to the corresponding cell centroid from the NOAA dataset; if less than 50 percent of a cell area was over water, the elevation was assigned to the cell centroid from ENP maps; where data were lacking from any other sources, values were assigned to vertices and centroids from the NOAA dataset. The U.S. Army Corps of Engineers LIDAR data were used for comparison purposes only.

The elevations assigned to the cell vertices and centroids were then modified to better represent the hydrologic system in the model. A value of $-0.25 \mathrm{~m}$ NAVD 88 represents mean sea level (msl) in the model, so vertices and centroids representing the coastline and located between land and water were assigned this elevation. Biscayne Bay is bounded to the east by a series of barrier islands that separate it from the Atlantic Ocean. These islands are represented in the model by assigning 1-m NAVD 88 cell elevations to appropriate vertices and cell centroids. To correctly simulate the direction of flow at a coastal canal discharge point, if the sampled elevation of a downstream vertex was higher than the adjacent upstream vertex, a lower elevation was assigned to the downstream vertex. Figure 5 displays the land-surface topography and bathymetry used in the model.

\section{Hydraulic Properties}

Hydraulic properties are classified here as those parameters that characterize flow and transport within the groundwater system, flow and transport through the surface-water system, and flow and transport between the surface-water and groundwater systems. For the groundwater component of the model, aquifer hydraulic conductivity, anisotropy, storage, and porosity are user specified. For the surface-water component of the model, Manning's $n$ friction factor is user specified. User defined leakage parameters are specified to characterize flow and transport between the surface-water and groundwater systems. These terms are defined in the following sections.

\section{Aquifer Properties}

Aquifer hydraulic properties specified for the groundwater component of the model include horizontal hydraulic conductivity, vertical anisotropy ratio (for calculating vertical hydraulic conductivity), primary and secondary storage (storativity; for confined and convertible conditions), and effective porosity (table 1). With the exception of horizontal hydraulic conductivity, all of the aquifer property values described here were taken from the previously calibrated USGS model of the Biscayne aquifer (Langevin, 2001). Horizontal hydraulic conductivity values are derived from published transmissivity data from borehole cores, aquifer tests, and from other methods (Fish and Stewart, 1991). Where sufficient well construction information is available, transmissivity values were divided by the length of the open (or screened) borehole to determine horizontal hydraulic conductivity at a specific location. Hydraulic conductivity values were kriged using a simple linear variogram across the grid to provide horizontal hydraulic conductivity values for the entire model domain (fig. 6). Hydraulic conductivities could not be calculated for each flow and confining unit within the Biscayne aquifer due to sparse data, so the interpolated values were assumed to represent a composite hydraulic conductivity of the entire aquifer, and values were assigned uniformly in the vertical direction. A uniformly distributed anisotropy ratio of 100:1 for horizontal to vertical hydraulic conductivity was used to assign vertical hydraulic conductivity values across the grid (Langevin, 2001). Primary storage for layers $1-3$ was assigned a value of 0.02 (unitless; derived by a trial-and-error method to allow for stability between the surface and groundwater components of the model), while a value of 5.9E-5 was assigned to layers 4-20 (Langevin, 2001). Secondary storage, which is required for transient flow as well as solute-transport calculations, was specified as 0.2 (Merritt, 1997). Porosity, which is required for solute-transport calculations, was set at 0.2 (unitless).

\section{Surface-Water Properties}

Manning's $n$ values, which represent the frictional resistance of horizontal flow in the surface-water component of the model, were assigned to each model cell to calculate surface-water flow between vertices on the basis of distribution of land use as categorized in the SFMWD 1995 land-use geographic information system (GIS) data layer (South Florida Water Management District, 1995). Manning's $n$ values vary by vegetation type, and each vegetation type corresponds to a land-use type (Swain and others, 2004; table 2). For urban land use, a large value of Manning's $n$ was assigned to restrict horizontal flow and thus allow vertical leakage to the aquifer to dominate. In some cases, multiple land-use types are contained within a single model cell (fig. 7). In these cases, land-use types were fractionally weighted by area within each cell and summed to determine the Manning's $n$ value for that cell.

In general, the surface-water component of the model requires specification of two Manning's $n$ values for flow in each orthogonal direction, in this case, the north-south and east-west directions. Data required to differentiate between directional flow resistances were not available for most model cells, so a uniform value was applied for the east-west and north-south directions of each model cell. Lower resistance terms were applied in cells representing downstream canal reaches from coastal discharge structures to ensure flow was toward the bay.

\section{Groundwater/Surface-Water Leakage Properties}

The leakage routine in FTLOADDS was applied to simulate the movement of water between the groundwater and surface-water systems. The routine defines a transitional layer, which was originally defined to account for layered peat deposits in the ENP (referred to as the "thin layer" in Wang and others, 2007) through which water flows between the surface-water and groundwater systems. The leakage routine 


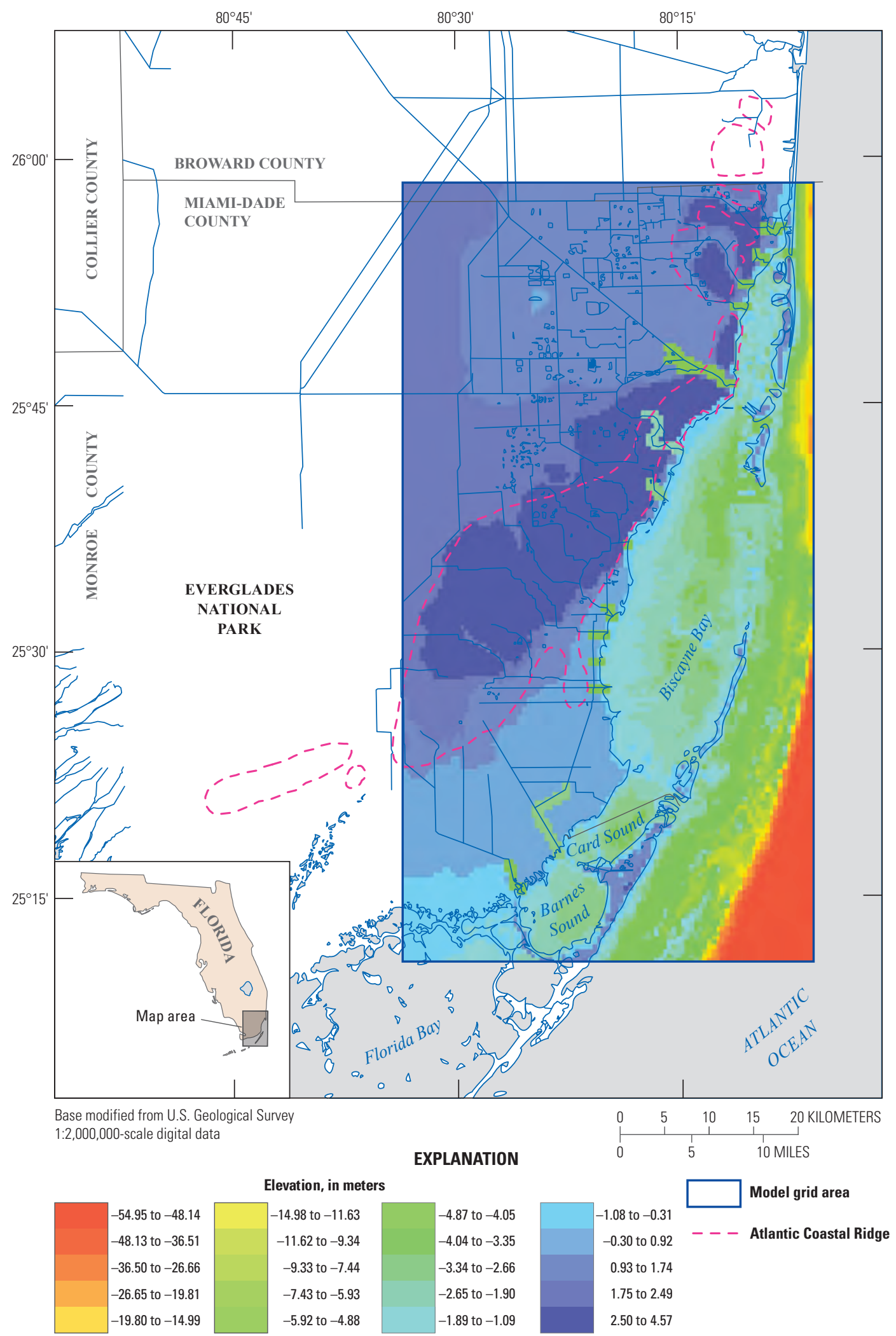

Figure 5. Model topography and bathymetry. Topography data were obtained from the Everglades National Park (ENP; 1-foot contours), the National Oceanic and Atmospheric Administration (NOAA) National Geophysical Data Center (NGDC) Coastal Relief Model dataset (including land elevations and bathymetry, http://www.ngdc.noaa.gov/mgg/bathymetry/relief.html, accessed July 20, 2012), and the U.S. Army Corps of Engineers Light Detection and Ranging (LIDAR) data system. 
Table 1. Aquifer property values used in model (from Langevin, 2001).

\begin{tabular}{lc}
\hline \multicolumn{1}{c}{ Aquifer property } & Value (unitless) \\
\hline Anisotropy & $100: 1$ \\
Porosity & 0.2 \\
Primary storage layers 1-3 & 0.02 \\
Layers 4-20 & $5.9 \times 10^{-5}$ \\
Secondary storage & 0.2 \\
\hline
\end{tabular}

uses three parameters and the calculated difference between the simulated surface-water stage and transitional layer head to calculate the volume of water passed between the surfacewater and groundwater systems (see appendix 1). The three user-defined parameters are (1) the transitional layer thickness (used to represent a surficial feature, such as peat, that would restrict flow), (2) the vertical hydraulic conductivity of the transitional layer, and (3) the vertical hydraulic conductivity of the aquifer cell itself. The transitional layer hydraulic conductivity is conceptually similar to the vertical hydraulic conductivity of the aquifer but is distinct and independently defined. Theoretically, in areas where there is little development of soil or fill, values of transitional layer hydraulic conductivity would correspond directly with the groundwater vertical conductivities. Values of transitional layer parameters also may be used to limit or maximize the leakage between the surface-water and groundwater systems.

Most of the model domain is urban and essentially no intermediate layer, for example peat, exists between the surface-water and groundwater systems. Accordingly, the transitional layer was assigned an extremely small thickness value $(0.0001 \mathrm{~m})$ and a high conductivity value (500 meters per day $(\mathrm{m} / \mathrm{d}))$ uniformly across the grid to allow the rapid transport of water between the land surface and the aquifer system. Along with a high surface-water stage, the surface water to groundwater gradient is high, which results in a high leakage rate. This essentially renders runoff negligible in urban areas, because Manning's $n$ is large, and water is routed directly through the transitional layer into the groundwater system. To prevent unrealistic leakage volumes over the groundwater time step, additional leakage limiters were used (see appendix 1).

\section{Boundary Conditions}

Boundary conditions describe how water and transported components, such as dissolved solutes or energy, enter and exit the modeled system, including, for example, through precipitation and ET, groundwater pumpage, and groundwater and surface-water inflow and outflow from beyond the modeled area. Boundary conditions are specified explicitly by the user or may be a function of model-simulated and user-specified conditions. Model boundaries are preferably defined at natural hydraulic boundaries, where water and solute concentration
Table 2. Manning's n coefficients used in model

[Land-use types obtained from the South Florida Water Management District's 1995 land-use Geographic Information System (GIS) data layer (South Florida Water Management District, 1995)]

\begin{tabular}{lc}
\hline \multicolumn{1}{c}{ Land-use description } & $\begin{array}{c}\text { Manning's-N value } \\
\text { (unitless) }\end{array}$ \\
\hline $\begin{array}{l}\text { Urban, transportation, } \\
\text { barren land }\end{array}$ & 0.25 \\
Agriculture & 0.3 \\
Rangeland & 0.2 \\
Open water & 0.02 \\
Upland forest & 0.4 \\
Wetlands & 0.125 \\
\hline
\end{tabular}

entering and leaving the simulated system can be easily measured or assumed, such as the ocean, or where an aquifer receives direct recharge, but it is not always possible or practical to do so. For the Biscayne model, the simulated surfacewater component of the system is bounded by the Atlantic Ocean and Florida Bay to the east and south, and by canals to the north and west (fig. 3). Water also enters the canal system at the coastal control structures (fig. 3) and enters and exits the system by precipitation and ET. The simulated groundwater component of the system is bounded from below by a relatively low hydraulic conductivity confining unit, on the west and north by regional groundwater flow from the Everglades, and on the east and south by sub-seafloor groundwater flow (fig. 4). Water is also removed from the groundwater component of the system by groundwater withdrawals at municipal well fields (fig. 1).

\section{Groundwater Flux at Model Extent}

Groundwater flows generally from the Everglades region to the east into and across the study area. To represent the regional groundwater flux into the study area, a headdependent flux was implemented at the northern, western, and southwestern extents (C-9, L30 and L-31, and C-111 canals) of the active model domain (orange line, fig. 4), for all model layers except the top layer (layers 2-20; appendix 3). Groundwater head data near the northern and western model boundary are lacking, so the controlling head for the headdependent flux was set at the elevation of the time-varying canal stage along the bordering canals. Conductance values were calibrated, and resulting values were high enough that the boundary effectively behaved as a specified head boundary. Boundary conditions for the top model layer along the northern, western, and southwestern extents are described in the following section as for canal boundaries.

Along the southern and eastern model extent at the marine margins of the model, a no-flow boundary condition was implemented for all layers of the groundwater component of the model to prevent numerical instabilities from occurring 


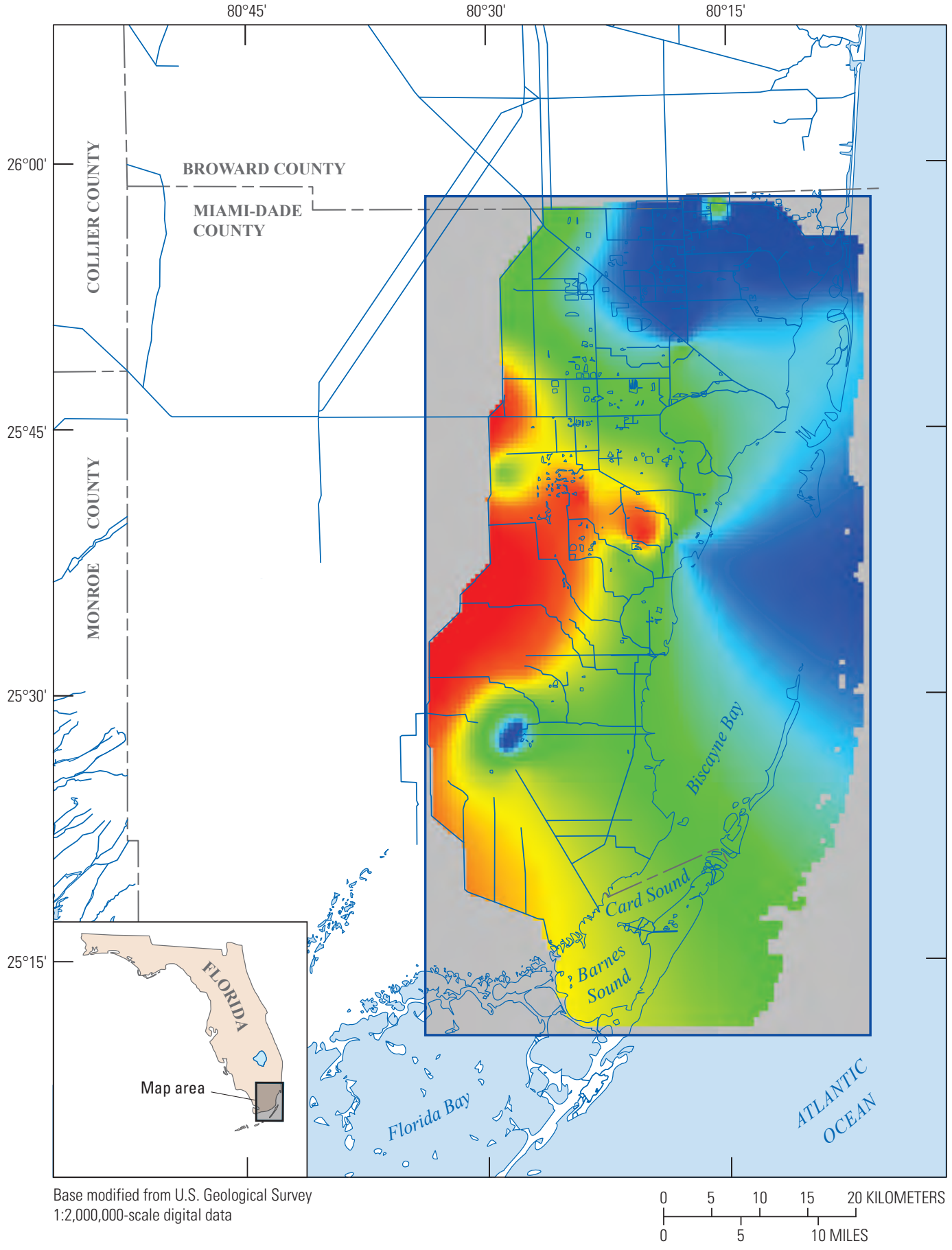

EXPLANATION

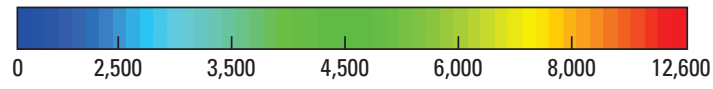

Estimated hydraulic conductivity of Biscayne aquifer, in meters per day

Model grid area

Figure 6. Horizontal hydraulic conductivity of the Biscayne aquifer interpolated from point field data collected by Fish and Stewart (1991). 


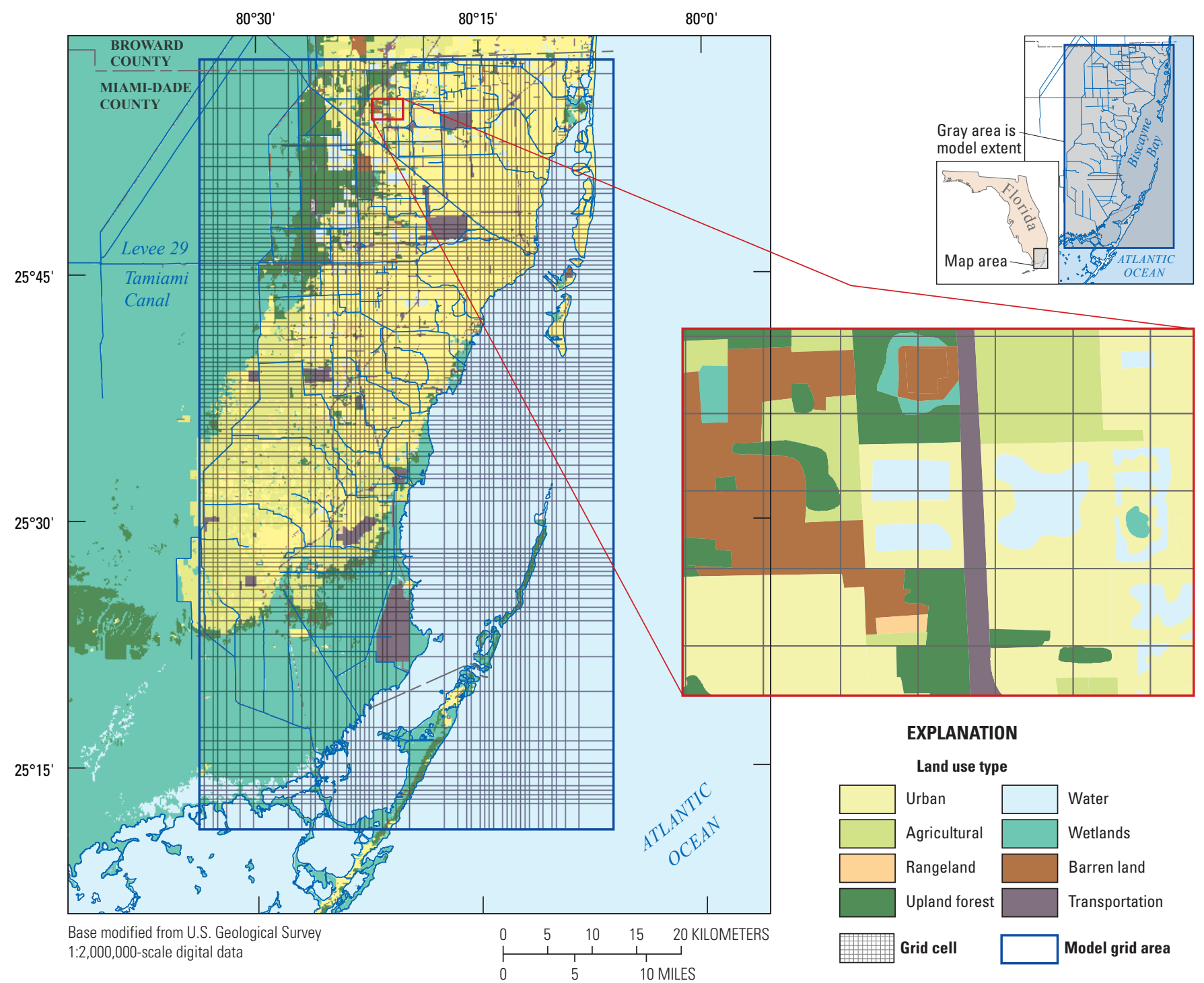

Figure 7. Land-use distribution (South Florida Water Management District, 1995) used to develop Manning's n values.

in the surface-water component of the model. This boundary condition effectively applies the assumption that the horizontal groundwater gradient is zero at the offshore boundary.

\section{Canal Boundaries}

The type of boundary conditions defined at major canals depends on whether flow in cells representing canals are calculated explicitly by the surface-water component of the model or act only as boundaries to the groundwater component of the model.

\section{Upstream from Coastal Control Structures}

Upstream from the major coastal canal control structures (fig. 4), canals provide a head-dependent flux boundary condition for the groundwater component of the model and effectively represent base flow. This boundary condition is defined for 12 main canals and 14 associated tributaries, which are discretized into a total of 60 individual reaches, using the MODFLOW River Package, and applied to the top layer of groundwater model cells (fig. 4). Water levels assigned to the cells for 53 of the canal reaches were uniform within each reach and calculated as the mean of the upstream structure tail-water and downstream structure headwater stages for the control structures that define each reach. For the other seven reaches, the water level assigned to the cells varied along the reach for one of the following reasons: (1) the distance between the upstream and downstream control structures was large enough for a significant water-level difference to exist; (2) the reach contained multiple control structures; or (3) the stage values at the upstream and downstream control structures were highly variable. For the cells in these reaches, assigned water levels were calculated using a bilinear interpolation between the upstream tail water and the downstream 
structure headwater stages. Water levels at the tail water and headwaters of the control structures (table 3) were obtained from the SFWMD DBHYDRO database. The canal (river) bottom elevations were estimated.

The vertical hydraulic conductance (riverbed conductance in MODFLOW) for each cell in a reach was calibrated on the basis of an initial conductance calculated from the vertical hydraulic conductivity values assigned to the aquifer and the layer 1 and 2 cell thicknesses at that location. Final calibrated conductance values are given in table 3 . For some reaches, assigned conductance values were uniform for all cells within the reach, even if the hydraulic conductivities were variable, because model results were insensitive to varying the conductance values spatially.

\section{Downstream from Coastal Control Structures}

Downstream from 16 coastal control structures (fig. 4; table 4), flow within the canals was solved explicitly by the surface-water component of FTLOADDS, and exchange between surface water and groundwater was calculated internally between the surface-water and groundwater components of the model. Discharge rates at these structures were obtained from the DBHYDRO database for the simulation period between 1996 and 2004 and applied as volume source rates in the surface-water cells immediately downstream from each control structure.

\section{Tidal Boundaries}

Surface-water flux into and out of the simulated system along the eastern model boundary is specified by tidal conditions (column 93, rows 9-173, fig. 3). At this boundary, the surface-water stage was specified using sea-level elevation data collected at the NOAA tidal data station at Virginia Key (fig. 8). Spectral analysis of these data provided estimates of mean water level, tidal cycle frequency, amplitude of the tidal fluctuation, and the tidal cycle offset phase value (table 5). These data are used to calculate temporally variable sea-level elevation, which is specified for the surface-water cells along the Atlantic Ocean model boundary. Specified salinity was set to $35 \mathrm{psu}$, an approximate value for seawater.

\section{Precipitation}

Water enters the surface-water component of the model directly through precipitation. On the basis of model computations, some portion of the precipitation remains in the surfacewater flow system, while some is routed as infiltration into the groundwater system by way of the leakage formulation. Precipitation rates were spatially distributed into zones and applied to the surface-water cells. Daily rainfall data were obtained from the DBHYDRO database at 71 stations (fig. 8) between 1996 and 2004. For each station, the data were averaged for the 9-year simulation period and contoured to define the precipitation zones. On the basis of a qualitative summary of the rainfall distribution and to ensure consistency with the rainfall distribution patterns used in Wang and others (2007), precipitation in the model domain was distributed among four zones (fig. 8), within each of which precipitation is uniform. For every time step and within each zone, daily rainfall values for all stations were averaged and applied as precipitation input to each model cell.

\section{Evapotranspiration}

Evapotranspiration (ET) removes water from both the surface-water and groundwater components of the hydrologic system. Removal of water from the system by ET is incorporated into the model using a modified version of the PenmanMonteith formula for vegetated sites and the Penman formula for open-water sites (Swain and Decker, 2009; appendix 1).

$$
Q_{L H}=\frac{\Delta\left(Q_{A S R}-Q_{R}\right)+\left(\rho_{a} c_{p} / r_{a}\right)\left(e_{s}-e_{a}\right)}{\Delta+\gamma\left(1+r_{s} / r_{a}\right)}
$$

where

$$
\begin{array}{cl}
Q_{L H} & \text { is the latent heat, } \\
Q_{A S R} & \text { is net solar radiation flux or absorbed short- } \\
& \text { wave radiation, } \\
Q_{R} & \text { is long-wave radiation flux exchanged } \\
& \text { between the water surface and the } \\
& \text { surroundings, } \\
\rho_{a} & \text { is the density of air, } \\
c_{p} & \text { is the constant pressure specific heat of air, } \\
e_{s} & \text { is the saturation vapor pressure at the air } \\
& \text { temperature, } \\
e_{a} & \text { is the vapor pressure at the air temperature, } \\
\Delta & \text { is the slope of the saturation vapor-pressure } \\
\gamma & \text { curve, } \\
r_{s} & \text { is the psychometric constant, } \\
r_{a} & \text { is the bulk stomatal resistance, and }
\end{array}
$$

Using this formula, the rate of water removal from the surfacewater component of the system is a function of the latent heat, which is calculated using user-defined properties: air and water temperature, albedo, wind speed and direction, solar radiation, humidity, and the stomatic resistance of vascular plants (appendix 1). By using this approach, a potential evapotranspiration (PET) value can be calculated that the model then modifies by using the predicted water level to derive an actual ET rate (Eagleson, 1970). The data for these calculations were obtained from a variety of field stations (Virginia Key, P-33, OIH, S331W, and 3AS3WX) at 15-minute time steps and averaged to create a single input dataset (stations are listed in appendix 4 and shown in figure 8 as ET/wind sites). A uniform value of 0.28 was used for albedo. This value is larger than the value used for the Ten Thousand Islands area in Southwest Florida (Swain and Decker, 2009), because Swain and others (2010) found that albedo was higher in open-water areas, such as Biscayne Bay, than in vegetated areas. The aerodynamic resistance term was set to 100 divided by the 
Table 3. Canal reaches and locations, river bottom elevations, and vertical conductance used to set model boundary conditions for canals upstream from the coastal control structures.

[m, meter; $\mathrm{m}^{2} / \mathrm{d}$, meter squared per day; * indicates reaches that were bilinearily interpolated]

\begin{tabular}{|c|c|c|c|c|c|}
\hline \multirow{2}{*}{$\begin{array}{r}\text { Reach } \\
1\end{array}$} & \multirow[t]{2}{*}{ Location description (canal and structure names) } & \multirow{2}{*}{$\begin{array}{c}\begin{array}{c}\text { Number of } \\
\text { model cells }\end{array} \\
1\end{array}$} & \multirow{2}{*}{$\begin{array}{c}\text { Designated } \\
\text { river bottom } \\
\text { elevation } \\
\text { (meters) }\end{array}$} & \multicolumn{2}{|c|}{$\begin{array}{l}\text { Vertical hydraulic } \\
\text { conductance } \\
\text { or range } \\
\left(\mathrm{m}^{2} / \mathrm{d}\right)\end{array}$} \\
\hline & & & & $5.50 \mathrm{E}+04$ & \\
\hline 2 & Canal C-111 Between S18C and S197 & 19 & -4 & $1.94 \mathrm{E}+04$ & $2.61 \mathrm{E}+05$ \\
\hline 4 & Canal C-111 Between S176 and S177 & 17 & -4 & $9.12 \mathrm{E}+04$ & $1.17 \mathrm{E}+05$ \\
\hline 5 & Canal C-111 Between S173/S331 and S176 & 29 & -4 & $1.18 \mathrm{E}+04$ & $4.49 \mathrm{E}+05$ \\
\hline 6 & Canal C-111 Between G211and S173/S331 & 11 & -4 & $5.35 \mathrm{E}+04$ & $8.30 \mathrm{E}+05$ \\
\hline 7 & Canal L-31N Between S24A and G211/S338 & 13 & -4.6 & $5.65 \mathrm{E}+05$ & $8.01 \mathrm{E}+05$ \\
\hline 11 & Canal L-30 to C-9 Btw S337/S32/S32A/S31 and S30 & 5 & -4 & $2.92 \mathrm{E}+05$ & $3.78 \mathrm{E}+05$ \\
\hline$* 12$ & Canal C-9 Between S30 and S29 & 58 & -4 & $5.11 \mathrm{E}+04$ & $5.11 \mathrm{E}+06$ \\
\hline 13 & Canal C-9 Below S29 & 1 & -4 & $1.62 \mathrm{E}+05$ & \\
\hline 14 & Structure G58 & 1 & -4 & $5.40 \mathrm{E}+04$ & \\
\hline 15 & Canal C-8 Below S28 & 1 & -5.2 & $2.12 \mathrm{E}+05$ & \\
\hline 16 & Canal C-8 Above S28 & 36 & -5.2 & $4.49 \mathrm{E}+04$ & $1.02 \mathrm{E}+06$ \\
\hline 17 & Canal C-7 Below S27 & 2 & -4 & $4.50 \mathrm{E}+04$ & $1.23 \mathrm{E}+05$ \\
\hline 23 & Canal C-3 Between S25B and Canal C-6 & 1 & -3.4 & $7.26 \mathrm{E}+04$ & \\
\hline 24 & Canal C-3 Below G93 & 1 & -1.5 & $6.06 \mathrm{E}+04$ & \\
\hline$* 25$ & Canal C-2 Between Canal C-4 and S22/S121 & 35 & -3.4 & $1.47 \mathrm{E}+03$ & \\
\hline 26 & Canal C-2 Below S22 & 1 & -3.4 & $2.72 \mathrm{E}+05$ & \\
\hline 27 & Canal C100C Between S121 and S119 & 12 & -1.8 & $6.63 \mathrm{E}+04$ & $5.40 \mathrm{E}+05$ \\
\hline 28 & Canal C100B Btw S122/S118/S119/S120 and S123 & 36 & -3.2 & $1.03 \mathrm{E}+04$ & $7.15 \mathrm{E}+05$ \\
\hline 29 & Canal C100B Below S123 & 1 & -3.4 & $4.77 \mathrm{E}+04$ & \\
\hline 30 & Canal C-100 Above S118 & 16 & -3.4 & $5.24 \mathrm{E}+03$ & $8.73 \mathrm{E}+04$ \\
\hline 31 & Canal C100B Between S122/S149/S148 and S21 & 18 & -3.7 & $2.16 \mathrm{E}+04$ & $2.54 \mathrm{E}+05$ \\
\hline 32 & Canal C-1N Above S149 & 33 & -1.8 & $2.22 \mathrm{E}+03$ & $1.89 \mathrm{E}+05$ \\
\hline$* 33$ & Canal C-1 Between S338 and S148 & 34 & -3.4 & $3.63 \mathrm{E}+04$ & $4.59 \mathrm{E}+05$ \\
\hline 34 & Canal C-1 Between G211 and S338 & 3 & -3.4 & $3.59 \mathrm{E}+05$ & $3.86 \mathrm{E}+05$ \\
\hline
\end{tabular}


Table 3. Canal reaches and locations, river bottom elevations, and vertical conductance used to set model boundary conditions for canals upstream from the coastal control structures.-Continued

$\left[\mathrm{m}\right.$, meter; $\mathrm{m}^{2} / \mathrm{d}$, meter squared per day; * indicates reaches that were bilinearily interpolated]

\begin{tabular}{|c|c|c|c|c|c|}
\hline Reach & Location description (canal and structure names) & $\begin{array}{l}\text { Number of } \\
\text { model cells }\end{array}$ & $\begin{array}{c}\text { Designated } \\
\text { river bottom } \\
\text { elevation } \\
\text { (meters) }\end{array}$ & \multicolumn{2}{|c|}{$\begin{array}{c}\text { Vertical hydraulic } \\
\text { conductance } \\
\text { or range } \\
\left(\mathbf{m}^{2} / \mathbf{d}\right)\end{array}$} \\
\hline 35 & Canal C100B Below S21 & 1 & -3.4 & $1.33 \mathrm{E}+05$ & \\
\hline 36 & Canal C-102 Below S21A & 1 & -3.4 & $2.31 \mathrm{E}+05$ & \\
\hline *37 & Canal C-102/ C-102N Between S165/S195 and S21A & 21 & -3.4 & $8.47 \mathrm{E}+04$ & \\
\hline 38 & Canal C-102N Above S195 & 5 & -2.7 & $8.47 \mathrm{E}+04$ & \\
\hline 39 & Canal C-102 Between S194 and S165 & 18 & -1.7 & $8.47 \mathrm{E}+02$ & \\
\hline 40 & Canal C-102 Between C-111 and S194 & 10 & -1.7 & $3.10 \mathrm{E}+05$ & $3.67 \mathrm{E}+05$ \\
\hline 41 & Canal L-31E Above S21 & 8 & -3.4 & $7.69 \mathrm{E}+04$ & $1.50 \mathrm{E}+05$ \\
\hline 42 & Canal L-31E Between S21 and S21A & 8 & -3.4 & $4.46 \mathrm{E}+04$ & $2.29 \mathrm{E}+05$ \\
\hline 43 & Canal L-31E Between S21A and S20G & 5 & -3.4 & $4.36 \mathrm{E}+05$ & $4.79 \mathrm{E}+05$ \\
\hline 44 & Below S20G & 1 & -3.4 & $4.77 \mathrm{E}+05$ & \\
\hline 45 & Canal L-31E Between S20G and S20F & 3 & -3.4 & $4.78 \mathrm{E}+05$ & \\
\hline 46 & Below S20F & 1 & -3.4 & $4.78 \mathrm{E}+05$ & \\
\hline 47 & Canal C-103 Between S179 and -20F & 15 & -4 & $2.25 \mathrm{E}+05$ & $4.80 \mathrm{E}+05$ \\
\hline 48 & Canal C-103N Between S166 and S179 & 11 & -3.4 & $4.23 \mathrm{E}+04$ & $3.58 \mathrm{E}+05$ \\
\hline 49 & Canal C-103N Above S166 & 7 & -2.4 & $1.90 \mathrm{E}+05$ & $2.56 \mathrm{E}+05$ \\
\hline 50 & Canal C-103 Between S167 and S179 & 13 & -3.4 & $2.17 \mathrm{E}+04$ & $4.50 \mathrm{E}+07$ \\
\hline 51 & Canal C-103 Between S196 and S167 & 10 & -1.8 & $2.51 \mathrm{E}+04$ & $1.61 \mathrm{E}+05$ \\
\hline 52 & Canal C-103 Between Canal C-111 and S196 & 10 & -3.4 & $8.58 \mathrm{E}+04$ & $2.67 \mathrm{E}+05$ \\
\hline 53 & Canal L-31E Between S20F and S20 & 23 & -3.4 & $1.53 \mathrm{E}+05$ & \\
\hline 54 & Canal L-31E Canal East of S20 & 2 & -3.4 & $1.53 \mathrm{E}+05$ & $8.24 \mathrm{E}+05$ \\
\hline 56 & Open Canal 2 below S20F East of L-31E & 3 & -3.4 & $9.69 \mathrm{E}+04$ & \\
\hline 57 & Canal between $\mathrm{S} 25 \mathrm{~A}$ and $\mathrm{S} 25$ & 6 & -5.8 & $1.47 \mathrm{E}+04$ & \\
\hline 58 & Open Canal 1 below S20F behind L-31E canal & 23 & -3.4 & $6.30 \mathrm{E}+03$ & \\
\hline 59 & Open Canal 2 below S20F behind L-31E canal & 24 & -3.4 & $6.30 \mathrm{E}+03$ & \\
\hline 60 & South of S20 Model lands canal (use reach 1) & 34 & -3.4 & $5.83 \mathrm{E}+03$ & \\
\hline
\end{tabular}


Table 4. Coastal control structures for which discharge rates were applied as influx into the canal system.

\begin{tabular}{|c|c|c|c|c|c|}
\hline Site name & Latitude & Longitude & Site name & Latitude & Longitude \\
\hline G58 & $25^{\circ} 54^{\prime} 00^{\prime \prime}$ & $80^{\circ} 09^{\prime} 43^{\prime \prime}$ & S21A & $25^{\circ} 31^{\prime} 09^{\prime \prime}$ & $80^{\circ} 20^{\prime} 46^{\prime \prime}$ \\
\hline G93 & $25^{\circ} 44^{\prime} 18^{\prime \prime}$ & $80^{\circ} 17^{\prime} 12^{\prime \prime}$ & S22 & $25^{\circ} 40^{\prime} 12^{\prime \prime}$ & $80^{\circ} 17^{\prime} 02^{\prime \prime}$ \\
\hline $\mathrm{S} 123$ & $25^{\circ} 36^{\prime} 37^{\prime \prime}$ & $80^{\circ} 18^{\prime} 28^{\prime \prime}$ & S25 & $25^{\circ} 47^{\prime} 52^{\prime \prime}$ & $80^{\circ} 14^{\prime} 44^{\prime \prime}$ \\
\hline S197 & $25^{\circ} 17^{\prime} 13^{\prime \prime}$ & $80^{\circ} 26^{\prime} 29^{\prime \prime}$ & $\mathrm{S} 25 \mathrm{~B}$ & $25^{\circ} 47^{\prime} 38^{\prime \prime}$ & $80^{\circ} 15^{\prime} 45^{\prime \prime}$ \\
\hline $\mathrm{S} 20$ & $25^{\circ} 22^{\prime} 01^{\prime \prime}$ & $80^{\circ} 22^{\prime} 35^{\prime \prime}$ & S26 & $25^{\circ} 48^{\prime} 29^{\prime \prime}$ & $80^{\circ} 15^{\prime} 39^{\prime \prime}$ \\
\hline $\mathrm{S} 20 \mathrm{~F}$ & $25^{\circ} 27^{\prime} 46^{\prime \prime}$ & $80^{\circ} 20^{\prime} 51^{\prime \prime}$ & S27 & $25^{\circ} 50^{\prime} 55^{\prime \prime}$ & $80^{\circ} 11^{\prime} 20^{\prime \prime}$ \\
\hline S20G & $25^{\circ} 29^{\prime} 21^{\prime \prime}$ & $80^{\circ} 20^{\prime} 50^{\prime \prime}$ & S28 & $25^{\circ} 52^{\prime} 15^{\prime \prime}$ & $80^{\circ} 10^{\prime} 42^{\prime \prime}$ \\
\hline $\mathrm{S} 21$ & $25^{\circ} 32^{\prime} 35^{\prime \prime}$ & $80^{\circ} 19^{\prime} 51^{\prime \prime}$ & S29 & $25^{\circ} 55^{\prime} 42^{\prime \prime}$ & $80^{\circ} 09^{\prime} 03^{\prime \prime}$ \\
\hline
\end{tabular}

wind speed (meters per second). Stomatal resistance was set to 0.0 seconds per meter $(\mathrm{s} / \mathrm{m})$ when no vegetation was present and set to $140 \mathrm{~s} / \mathrm{m}$ when vegetation was present, which was calibrated in the TIME model (Wang and others, 2007). When the Penman formula was used, Brutsaert's (1982) equation for sensible heat flux was used to compute sensible heat.

Water is removed from the groundwater component of the simulated system as a function of user-defined PET (maximum flux), extinction depth, and elevation of the ET surface, as defined for the EVT package of MODFLOW-2000 (Harbaugh and others, 2000). Data calculations of PET were acquired from the TIME model because full ET measuring sites were not located within the Biscayne model domain. These estimates were originally obtained from the $\mathrm{OIH}$ and P-33 ET sites (fig. 8).

\section{Wind-Blown Surface Water}

Wind can move water into and out of the surface-water component of the system, particularly in low velocity, low gradient areas. Data on wind velocity and direction applied to the surface-water model were acquired from the NOAA Virginia Key weather station and from the USGS ET station located at Old Ingraham Highway (OIH; fig. 8). The datasets from these two sites were averaged in 15-minute increments and applied as a uniform wind field across the model grid. Although this averaging period may cause some differences along the coastline and in the bay by damping peaks in the wind field, the averaged dataset is still considered to provide a reasonably good estimate of wind velocity and direction.

\section{Groundwater Pumpage}

Municipal withdrawals from the Biscayne aquifer from 22 well fields within the model domain during the simulation period are reported to have ranged from $1.35 \times 10^{6}$ to
Table 5. Tidal properties used to specify boundary conditions at the Atlantic 0cean model boundary.

[As derived from a spectral analysis of water level data from the National Oceanic and Atmospheric Administration Virginia Key data station, accessed April 22, 2005, at http://tidesandcurrents.noaa.gov/. PSU, practical salinity units]

\begin{tabular}{ll}
\hline \multicolumn{1}{c}{ Tidal property } & Value \\
\hline Frequency (radians $\left./ \mathrm{sec} \times 10^{-4}\right)$ & 1.40519 \\
Mean water level (meters) & -0.2 \\
Amplitude (meters) & 0.35 \\
Phase (radians) & 1.97 \\
Salinity (PSU) & 35 \\
\hline
\end{tabular}

$1.68 \times 10^{6} \mathrm{~m}^{3} / \mathrm{d}$ (cubic meters per day; 350 to 450 million gallons per day; fig. 9). For each of 127 wells, pumpage data provided by the Miami-Dade Water and Sewer Department as hourly, daily, or monthly volumetric totals were converted to daily pumpage rates corresponding with the length of the groundwater solution stress period. For the wells for which daily values were not provided, hourly pumpage values were averaged for each 24-hour period, and average monthly pumpage volumes were divided by the number of days in the month to calculate daily pumpage rates. Converting the data as described resulted in a smoother temporal distribution of pumpage than actually occurred; when hourly values were averaged over a 24-hour period, shorter-duration hourly peaks were omitted. Yet when monthly total volumes were distributed over the days in a month, many pumping peaks were obscured. Pumpage data were applied to model cells using the MODFLOW Well Package. 


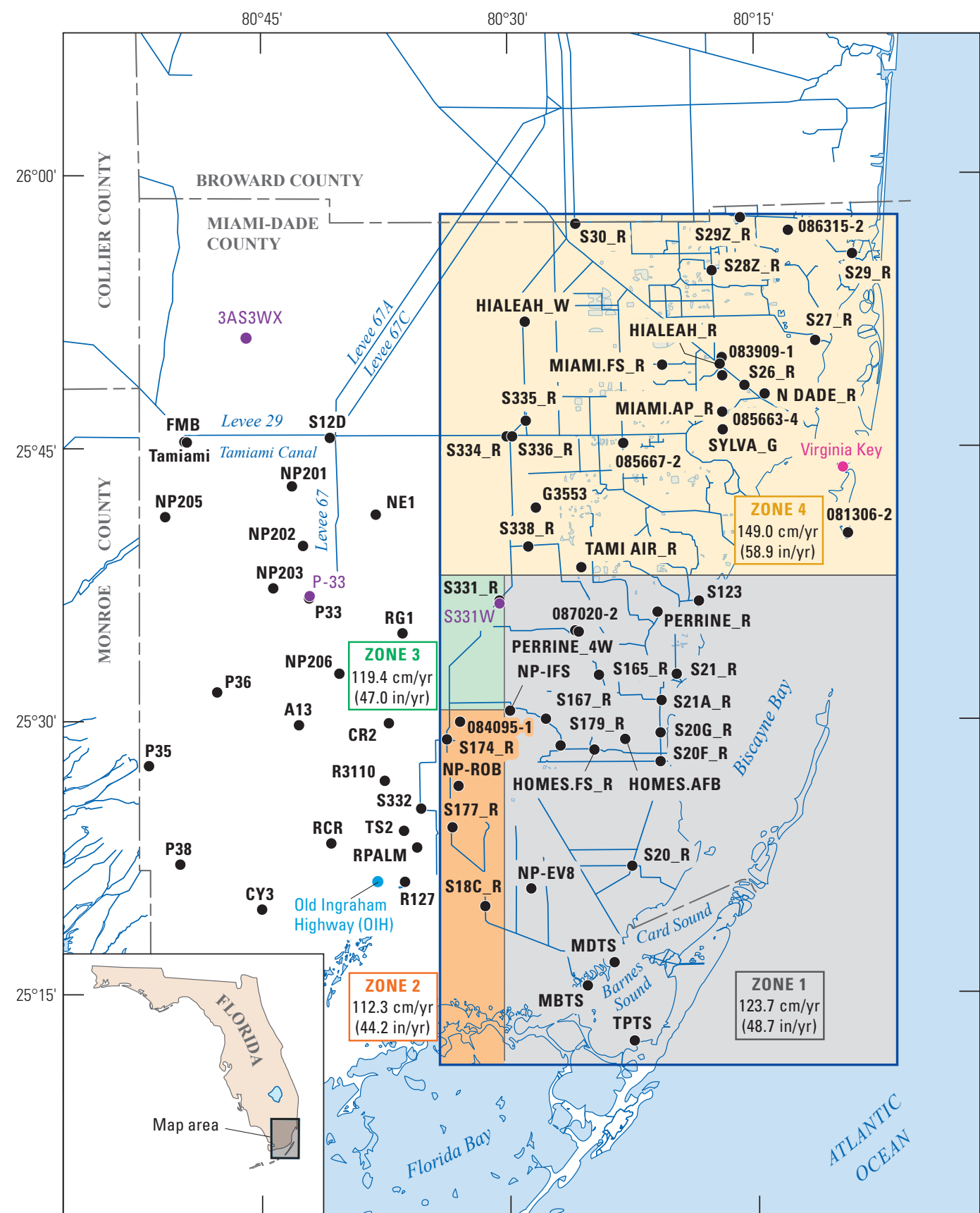

Base modified from U.S. Geological Survey $1: 2,000,000$-scale digital data

EXPLANATION

\begin{tabular}{|c|c|}
\hline 70NF 4 & Rainfal \\
\hline ZUIVE 4 & -In centimete \\
\hline $\begin{array}{l}149.0 \mathrm{~cm} / \mathrm{yr} \\
(58.9 \mathrm{in} / \mathrm{yr})\end{array}$ & $\begin{array}{l}\text { and inches per year, } \\
\text { (cm/vr and in } / \mathrm{vr} \text { ) }\end{array}$ \\
\hline
\end{tabular}

Model grid area

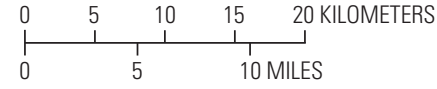

Data station symbol and site Evapotranspiration

Evapotranspiration and wind

- Virginia Key Wind and tidal

- S123 Rainfall

Figure 8. Locations of wind, evapotranspiration, rainfall, and tidal data sites. Rainfall zones used in the model are displayed, including the calculated average rainfall rate, in centimeters per year, for each zone for the 9-year period, 1996-2004. 


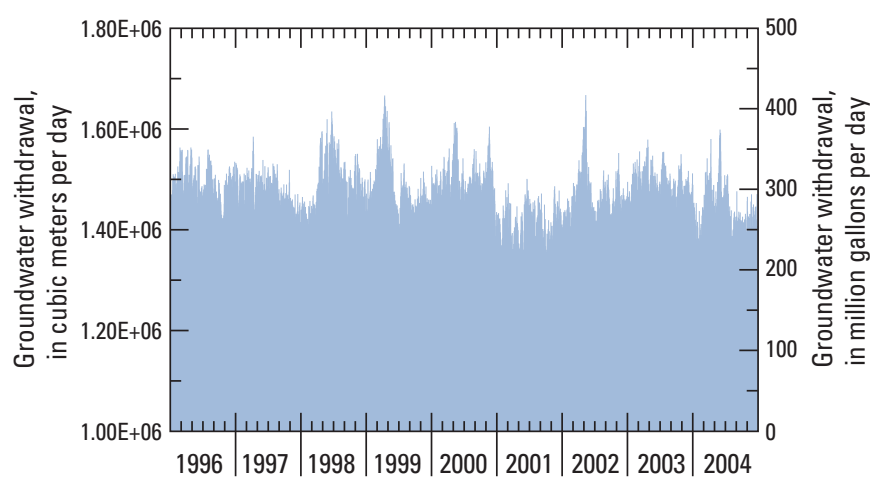

Figure 9. Daily total municipal pumpage applied to the model from well fields, 1996-2004.

\section{Initial Conditions}

Transient hydrologic simulations require the establishment of reasonable initial conditions if and where they are unknown. To establish initial conditions for the 1996-2004 forward simulation, the model was executed for a period of 140 simulated years until the model represented a near-steady state distribution of groundwater heads, and a stable salt-mass distribution. Specifically surface-water stages initially were set to zero ft NAVD 88 for all cells, and surface-water salinities were set at 35 psu for Bay and offshore cells and zero psu for onshore cells. This provides a reasonable representation of the dry season conditions that existed on January 1, 1996, the beginning of the simulation period. The model was run repeatedly (approximately 16 times) using the stress data for the 1996-2004 simulation period in order to generate initial groundwater levels and concentrations. The simulated heads and salinities at the end of each run were incorporated as the initial heads and salinities for each subsequent run until the salinity in the Biscayne aquifer achieved an approximate steady state distribution. The resulting head and salinity distribution were used as the initial conditions for the 1996-2004 simulation.

\section{Simulation of the Hydrologic System and Model Fit}

The model simulates estimated groundwater heads and salinity, canal base flow, and surface-water salinity and temperature for 1996-2004. This simulation was calibrated and is referred to as the base case scenario. The model was calibrated by manually adjusting the aquifer horizontal and vertical hydraulic conductivities, the canal hydraulic conductance, albedo, the thickness and the hydraulic conductivity of the transitional layer, the hydraulic conductance of the General Head Boundary (GHB), and the storage parameters to qualitatively match observed daily groundwater levels, estimated daily canal base flows, and monthly Biscayne Bay surfacewater salinity and temperature.

\section{Groundwater Heads}

Simulated and observed groundwater heads were compared at 47 sites selected on the basis of completeness of record and spatial distribution within the model domain (fig. 10). The model fit was evaluated by comparing the simulated data to the measured time-series data at individual stations and calculating error statistics for both individual stations and the entire model domain. Three error statistics are commonly used to quantify the average error of the calibration: (1) the mean error (ME), or the average of the differences between the simulated and observed values; (2) the mean absolute error (MAE), which is the average of the absolute differences between the simulated and observed values; and (3) the root mean square error (RMSE), the square root of the average of the squared differences between simulated and observed values (Anderson and Woessner, 1992). These error statistics were calculated for all 154,536 daily observations at the 47 monitoring sites for an overall model ME of $0.12 \mathrm{~m}$, MAE of $0.22 \mathrm{~m}$, and RMSE of $0.33 \mathrm{~m}$ (table 6). The observed range of groundwater heads was between -3.53 and $2.97 \mathrm{~m}$. The positive value for ME indicates that the model is simulating heads that are, on average, higher than observed values. The MAE is 3 percent of the overall range of observed values (lowest measured head, in meters, minus highest measured head, in meters) and 11 percent of the average range of values at each of the 47 sites. The RMSE indicates that the majority of the simulated values are within plus or minus $0.33 \mathrm{~m}$ of the ME. The standard deviation of the residuals was 0.304 , and when divided by the range of observed values yields a normalized standard error value of 0.047 , which is below the suggested target value of 0.1 .

The total error calculated on a daily or monthly basis shows a distinct and persistent positive bias in ME, as well as MAE and RMSE (fig. 11). Some notable exceptions to the positive bias of the ME are negative values that correspond directly with major precipitation events in 1999 and 2000 (fig. 11A). These negative ME values are the result of the 1-day lag between the surface-water model solution and the groundwater model solution. The groundwater flow equation is solved on a daily time step basis, but the surface-water flow equations are solved on a 10-minute basis and sum these values over the day before passing the quantity to the groundwater system. Therefore, this averaged daily quantity of water passed from the surface-water system does not represent the actual rapid response of the groundwater system to major precipitation events. The lag between surface-water and groundwater solutions, however, cannot explain the positive bias. Averaging the error statistics over each month will smooth the resulting trends, reduce the extremes, and illustrate more clearly a seasonal bias in the error statistics (fig. 11B). All three of the error statistics are larger during the rainy season than during the dry season. The ME is near zero during most of the dry season, indicating that the seasonal bias may explain a substantial portion of the overall positive bias. The positive bias during the rainy season may be the result of less 


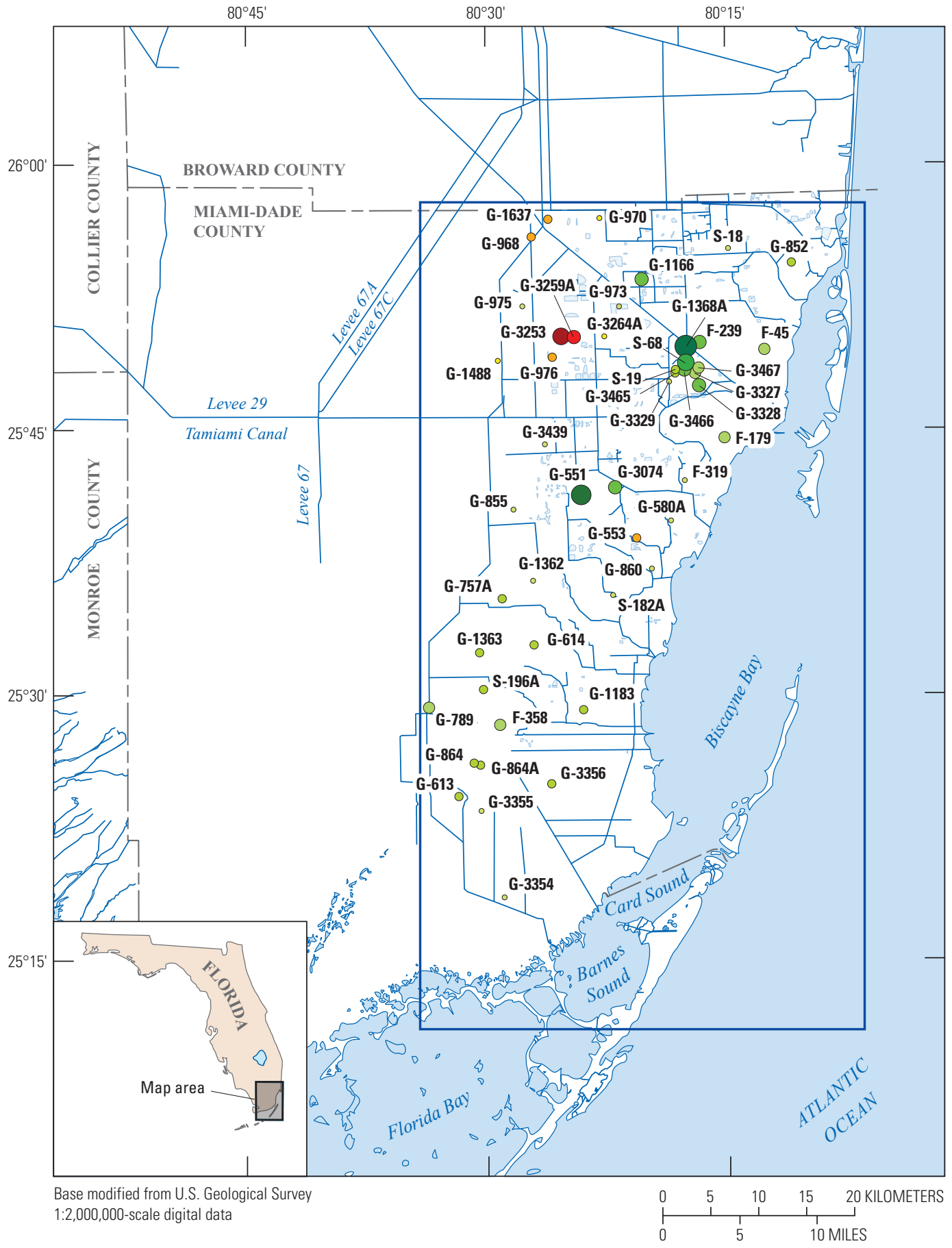

EXPLANATION

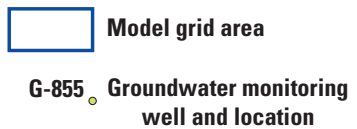

Mean error-In meters. Negative values indicate the simulated head is lower than the observed. Positive values indicate the simulated head is higher than the observed
-0.484 to $-0.400 \quad \bigcirc-0.199$ to $-0.100 \quad 0.101$ to 0.200
0.401 to 0.500
-0.399 to $-0.300 \quad \circ-0.099$ to $0 \quad 0.201$ to 0.300
0.501 to 0.600
-0.299 to -0.200 ○ 0.001 to $0.100 \bigcirc 0.301$ to 0.400
0.601 to 1.200

Figure 10. Locations of groundwater monitoring stations and the average differences, in meters, between model simulated and measured water levels, 1996-2004. 
Table 6. Mean error, mean absolute error, and root mean squared error for all groundwater observations for sensitivity test simulations, and percent difference total groundwater discharge and freshwater groundwater discharge between sensitivity test simulations and Base Case simulation.

[All values are in meters; N/A, value is not applicable as this test imposes zero flux across the bottom of Bay between the surface water and groundwater systems; PET, potential evapotranspiration]

\begin{tabular}{|c|c|c|c|c|c|}
\hline Sensitivity simulation & $\begin{array}{l}\text { Mean } \\
\text { error }\end{array}$ & $\begin{array}{l}\text { Mean } \\
\text { absolute } \\
\text { error }\end{array}$ & $\begin{array}{l}\text { Root mean } \\
\text { square error }\end{array}$ & $\begin{array}{c}\text { Percent } \\
\text { difference } \\
\text { in total } \\
\text { groundwater } \\
\text { discharge }\end{array}$ & $\begin{array}{c}\text { Percent } \\
\text { difference } \\
\text { in total fresh } \\
\text { groundwater } \\
\text { discharge }\end{array}$ \\
\hline Base Case: & 0.12 & 0.22 & 0.33 & & \\
\hline \multicolumn{6}{|l|}{ Leakage: } \\
\hline None & -0.15 & 0.23 & 0.35 & $\mathrm{~N} / \mathrm{A}$ & N/A \\
\hline Decreased & 0.12 & 0.21 & 0.33 & -22.8 & -2.49 \\
\hline \multicolumn{6}{|l|}{ River Conductance: } \\
\hline Increased one order of magnitude & 0.10 & 0.20 & 0.32 & -5.0 & -8.0 \\
\hline Decreased one order of magnitude & 0.40 & 0.47 & 0.62 & 0.0 & 3.2 \\
\hline \multicolumn{6}{|l|}{ Regional on-shore boundary condition: } \\
\hline No-flow & 0.12 & 0.22 & 0.33 & 3.6 & 4.4 \\
\hline $\begin{array}{r}\text { Controlling head of general head } \\
\text { boundary increased }\end{array}$ & 0.12 & 0.21 & 0.33 & -2.4 & -1.0 \\
\hline \multicolumn{6}{|l|}{ Evapotranspiration: } \\
\hline PET Doubled & 0.08 & 0.21 & 0.33 & -7.1 & -7.0 \\
\hline PET halved & 0.15 & 0.23 & 0.34 & 2.7 & 5.75 \\
\hline \multicolumn{6}{|l|}{ Aquifer Hydraulic Conductivity: } \\
\hline Double & 0.14 & 0.22 & 0.36 & 4.1 & 15.9 \\
\hline Half & 0.07 & 0.26 & 0.36 & -7.4 & -16.2 \\
\hline Average value distributed uniformly & 0.13 & 0.22 & 0.37 & 9.5 & 28.3 \\
\hline
\end{tabular}

water being routed into runoff or lost to ET in the model than in the actual system, resulting in an excess of water recharging the Biscayne aquifer and correspondingly higher simulated water levels.

Because of the high permeability of the hydrogeologic units in the study area, the groundwater system has a strong hydraulic connection to the surface-water system and is responsive to atmospheric conditions and input. The resulting model is sensitive to spatial variations in boundary conditions. The ME values calculated at each of the 47 observation sites over the simulation period indicate spatial bias in the model error (fig. 10). The ME values are largely positive in the northern coastal and southern regions of the model, and tend to be negative in the northern inland part of the model area. Proximity of some observation locations to the western general head boundary may explain some of the error. Along the southwestern part of the model boundary, the $\mathrm{C}-111$ canal stage is used as the controlling head for the general head boundary condition. This approach is reasonable because the intended purpose of the C-111 canal is to recharge water to the aquifer system, assuming a downward gradient between the canal and the underlying aquifer. In the model, this approach results in higher simulated groundwater heads than are observed in the region (positive ME values). In contrast, the L-31N canal and associated levee are designed to restrict elevated water levels to the west of the simulated area. Defining the boundary by canal stage does not explicitly account for groundwater flows under L-31N. Thus along the northern inland part of the model boundary where the L-31N canal stage is used as the controlling head for the general head boundary condition, the simulated heads are lower than observed water levels (negative ME values). 


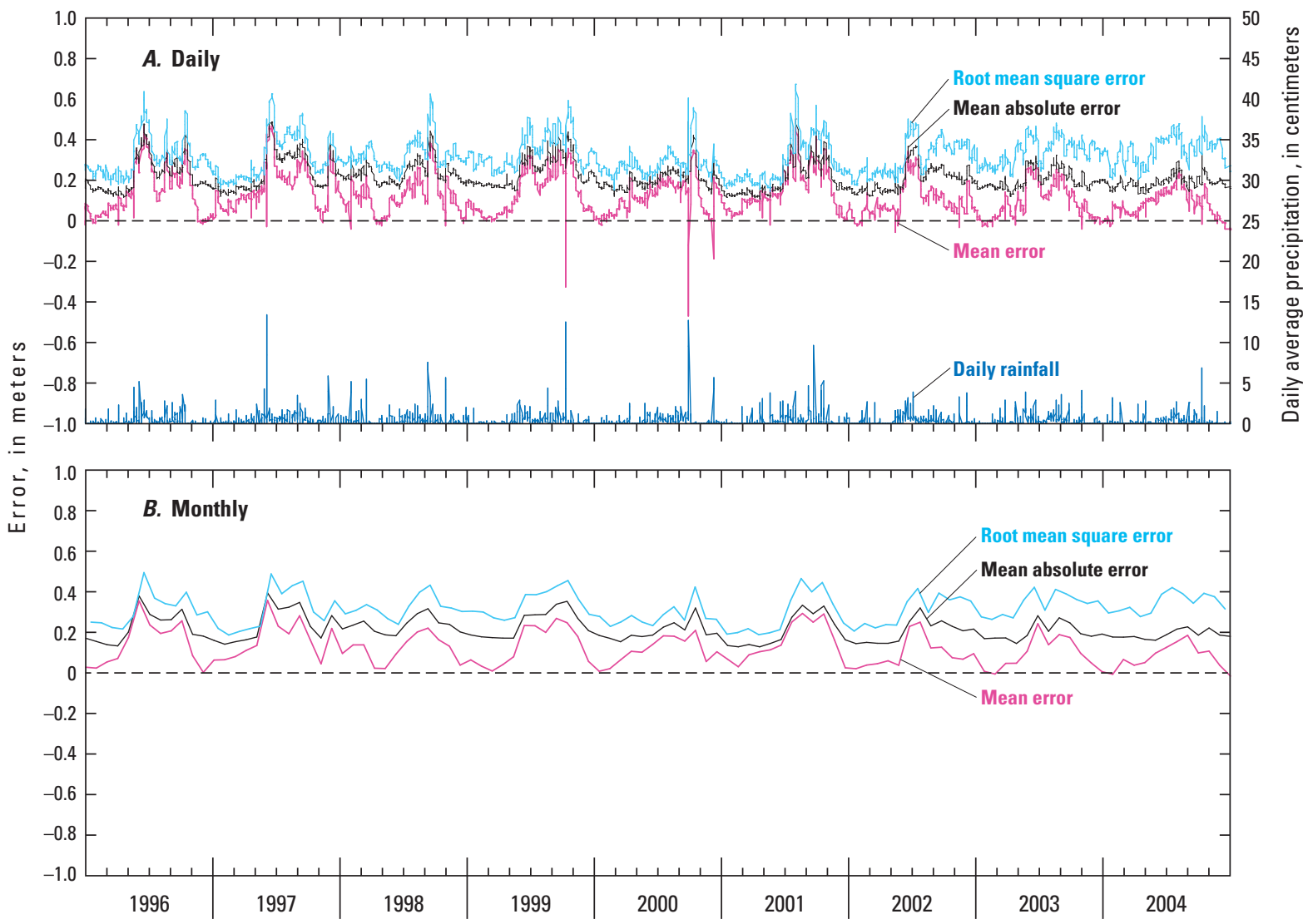

Figure 11. Mean error, mean absolute error, and root mean squared error, in meters, for all simulated groundwater heads for the 1996-2004 simulation period, shown $(A)$ daily, with daily average precipitation for all rainfall sites; and $(B)$ monthly.

A visual inspection of observed and simulated groundwater levels at 14 selected stations shows that simulated heads at a majority of the wells qualitatively match observed heads, both in amplitude and phase (fig. 12). Exceptions occur for stations located in cells with pumped well fields, such as G-3259A, or those close to the western boundary (G-789), where simulated heads are strongly controlled by proximity to the general head boundary. For stations located near pumped wells, a poor match between simulated and observed groundwater levels is partially because the model calculates a single drawdown value for the entire cell. This simulated drawdown value is typically less than what is observed close to the wells and more than what is observed at locations far from the wells. The western boundary and the well fields are at a distance from the area of interest, Biscayne Bay; therefore, the mismatches between observed and simulated heads in those areas are not considered critical to meeting model objectives.

\section{Canal Base Flow}

The model was also calibrated by adjusting the river conductance term in the MODFLOW River Package to match simulated to estimated daily base flow "observations." Observed canal base flows were generally calculated as the difference between the discharges measured at upstream (inflow) and downstream (outflow) control structures for 10 defined drainage basins. The 10 basins were selected on the basis of 13 water management basins identified by the U.S. Army Corps of Engineers (USACOE) and the SFWMD (Cooper and Lane, 1987; fig. 13). Because only half of the C-9 basin resides in the model domain, only half of the estimated base flow was used to compare with simulated values. Smaller agricultural canals, which connect to the primary canals and are unmeasured, are not represented in the model. The model simulates the daily volumetric exchange of water between the canals and the aquifer, with positive values representing flow 

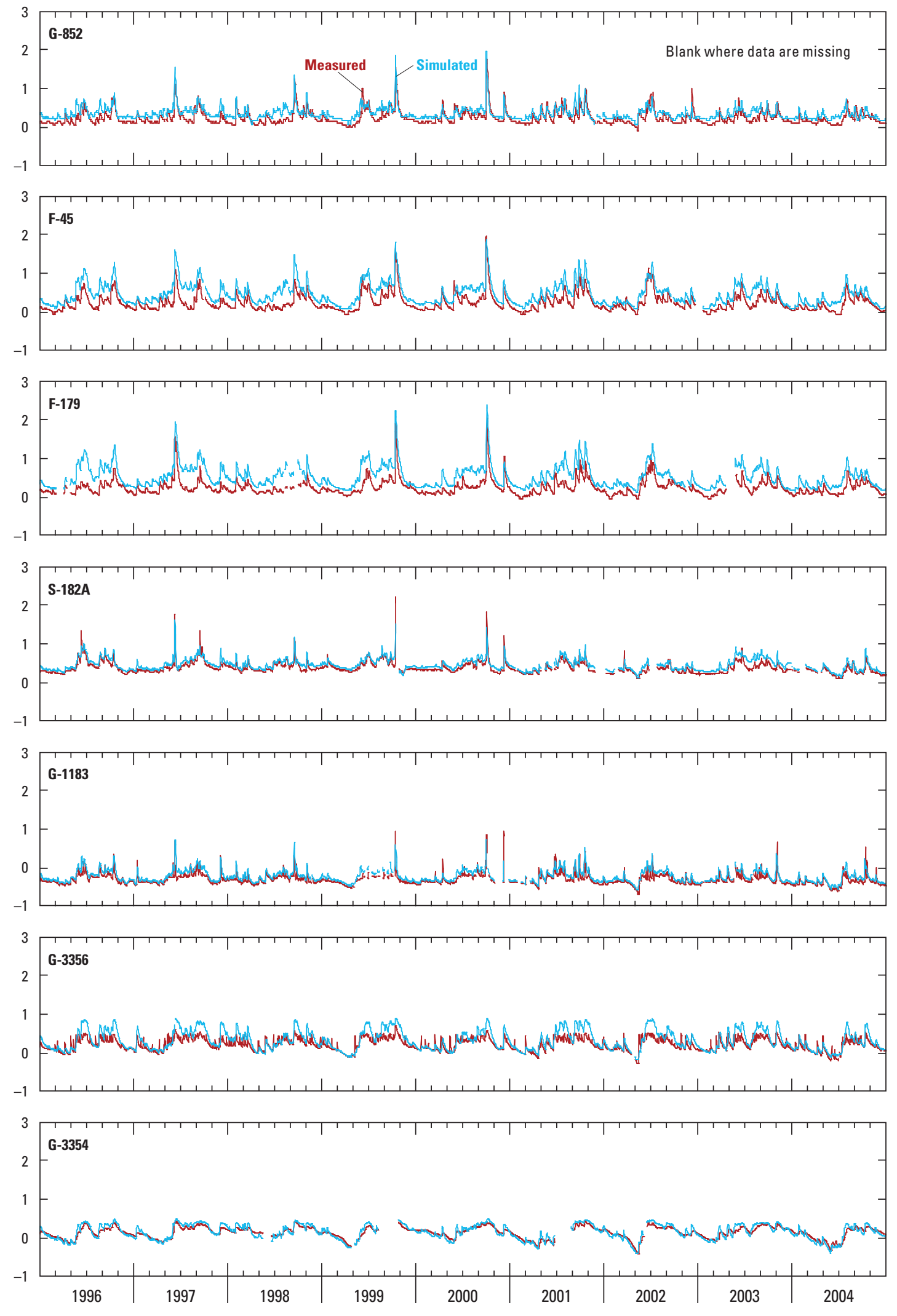

Figure 12. Simulated and measured daily water levels at selected groundwater monitoring sites (site locations shown in figure 10). 

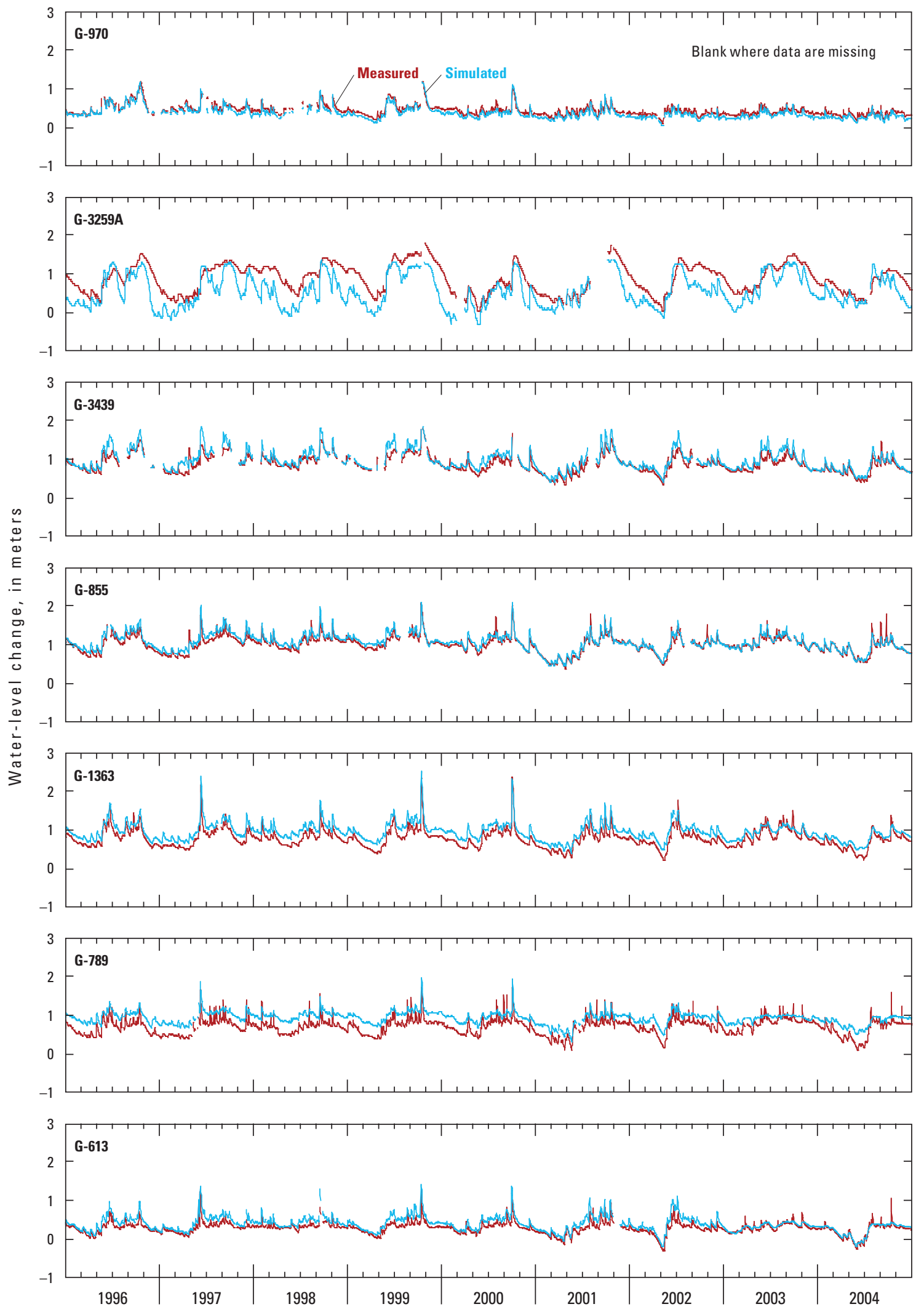

Figure 12. Simulated and measured daily water levels at selected groundwater monitoring sites (site locations shown in figure 10).-Continued 


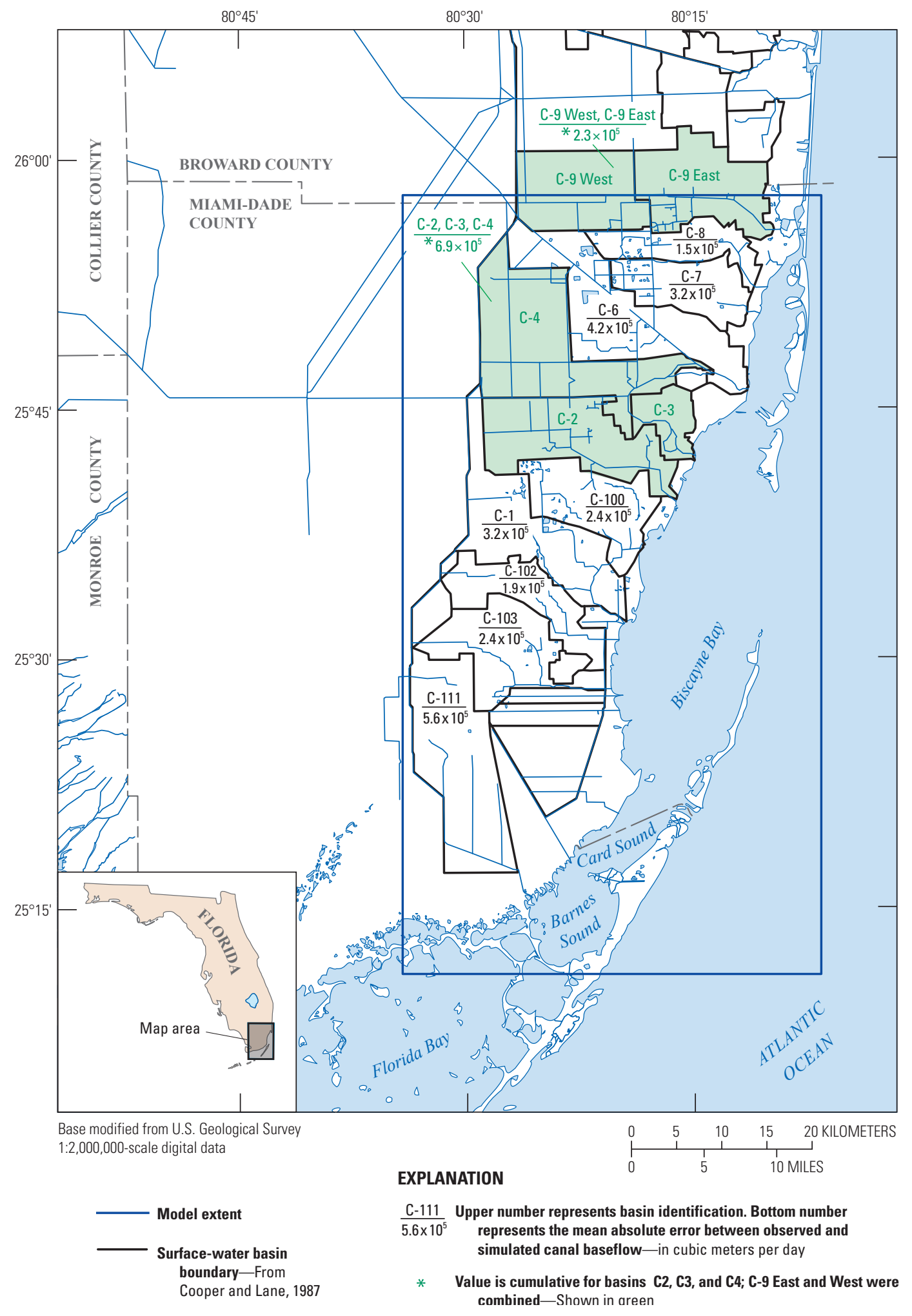

Figure 13. Mean absolute error, in cubic meters per day, between simulated and observed base flow in designated drainage basins, 1996-2004. Unnamed basins were defined by Cooper and Lane (1987), but errors are not reported because there are no structures in which to measure flows for the simulation period of 1996-2004. 
from the canals to the aquifer (recharge) and negative values representing flow from the aquifer to the canals (discharge). Surface-water runoff was not directly added to the canal flow, but infiltrated directly to the groundwater flow system by way of model cells around the canals.

In general, the simulated base flows have patterns and directions of flow similar to estimated canal base flows (fig. 14). Some of the differences between the magnitudes of simulated and estimated base flow may be attributed to the way surface-water runoff is simulated. Because surface-water runoff in the model recharges the aquifer cells adjacent to the canal and is not added directly to the canal, higher simulated heads proximal to canals may result, and thus simulated aquifer discharge to the canal may be higher, for example in the $\mathrm{C}-1$ basin, or simulated recharge from the canal to the aquifer may be lower, for example in basins C-1 and C-111. Smaller secondary and tertiary agricultural canals are not explicitly represented in the model, thus some reach gain or reach loss may be incorrectly attributed to base flow, resulting in an underestimation of the magnitude of the simulated base flow. This may account for the larger differences in the $\mathrm{C}-2$, C-3, C-4 basins than other basins. The base-flow estimate of the $\mathrm{C}-111$ basin, which was determined by using the difference in the flows from S-18C and S-197, is likely inaccurate because the western side of the canal levee was degraded to provide additional freshwater flows into the Everglades, resulting in an overestimation of the magnitude of the simulated base flow.

\section{Saltwater-Freshwater Interface}

The distribution of saltwater in the Biscayne aquifer was qualitatively calibrated to the interpreted saltwater-freshwater interface by running the model multiple times, each time reusing the predicted location of the interface as the initial conditions of the following run until a reasonable mass balance of the salinity in the aquifer was reached (fig. 15). It is important to represent the distribution of salinity in the aquifer to estimate the contribution to bay salinity from groundwater discharge because density differences across the saltwaterfreshwater interface affect the groundwater flow field and the quantity of water discharging into the bay. Simulated distribution of salinity at the base of the Biscayne aquifer at the end of the simulation period was compared with a measured estimate of the extent of saltwater intrusion in 1995 (Sonenshein, 1997) (fig. 16). The 1995 estimated extent of saltwater intrusion was determined using chloride concentration and borehole and surface-geophysical data at selected Miami-Dade County sites. Generally, site locations where measured or estimated chloride concentration exceed 100 milligrams per liter $(\mathrm{mg} / \mathrm{L}$; comparable to $0.1 \mathrm{psu}$ ) were considered on the saltwater side of the interface. Site locations with measured or estimated chloride concentration less than $100 \mathrm{mg} / \mathrm{L}$ were considered to be on the freshwater side of the interface. The 1995 estimated interface location represents the landward-most extent of the interface at the base of the aquifer and does not describe the geometry of the wedge-shaped interface. Therefore, it is not possible to directly compare the simulated interface with the measured one. The lack of comparability of the simulated and 1995 estimated extent of intrusion prohibits precise calibration with the mapped interface.

The simulated distribution of saltwater at the base of the Biscayne aquifer generally shows a more landward extent than the 1995 mapped position of the saltwater-freshwater interface, except at the southern end of the modeled area (fig. 16). Model and tidal boundary effects and errors in hydraulic property estimates may help explain the differences. In particular, the shape of the simulated distribution of salinity at the southern part of the model domain may be indicative of boundary effects.

\section{Biscayne Bay Salinity and Temperature Measurements}

Simulated surface-water salinity in Biscayne Bay was calibrated to match salinity and temperature data collected at 18 monitoring stations in Biscayne Bay, Coral Sound, and Barnes Sound (figs. 17 and 18). These stations are operated by the Florida International University (FIU) Southeast Environmental Research Center (SERC) Water Quality Monitoring Network (WQMN), which is supported by SFWMD/SERC Cooperative Agreement \#4600000352 and U.S. Environmental Protection Agency Agreement \#X7-96410603-3 (Boyer, 2004), and by Miami-Dade County DERM. At each of the SERC monitoring stations, monthly water salinity grab samples were collected near the top and the bottom of the water column. Values from the two samples were averaged and compared to the single value simulated by the model for a fully mixed system. At the two DERM monitoring stations, samples were collected as a single grab sample at 2-3 ft below the water surface.

The time series of simulated salinity values show similar seasonal patterns as those derived from measured values. The MAE of simulated salinity is 2.4 (fig. 18). The simulated salinity range is generally smaller than the measured salinity range, and this discrepancy is more pronounced for sites having a larger ranges (for example, NBL and FP, fig. 18B; and $\mathrm{CP}$ and WA, fig. 18C). The subdued variability of the simulated salinity is likely the result of temporal discretization. Simulated salinity represents a daily average, whereas measured salinity is likely to fluctuate throughout the day because of the tidal cycle and operation of the coastal canal structures. These effects would likely be more pronounced at the stations located in shallower waters and closer to canal discharge locations (compare, for example, stations NBL and $\mathrm{MN}$, fig. 18B). Simulated salinities at the stations in Barnes Sound (BB50 and BB51, fig. 18D) are generally higher than observed salinity, which is generally lower than at other stations. The higher salinity is likely due to two factors: the DERM samples were only collected at the top of the water column, and Barnes Sound is largely enclosed and lacks 


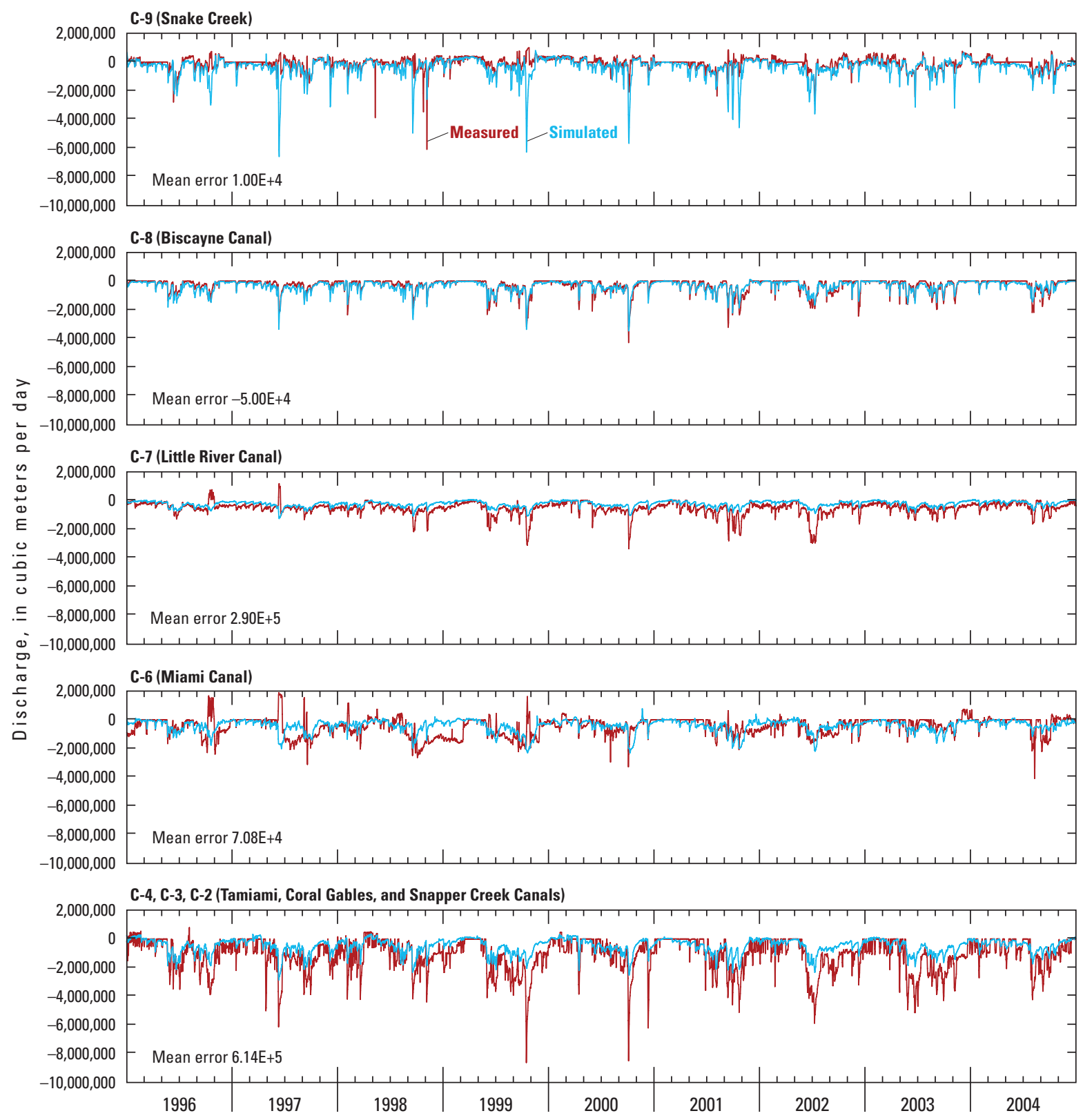

Figure 14. Simulated and measured daily canal base flow in designated drainage basins, 1996-2004. (Negative values represent flow from the aquifer. Site locations are shown in figure 13.) 


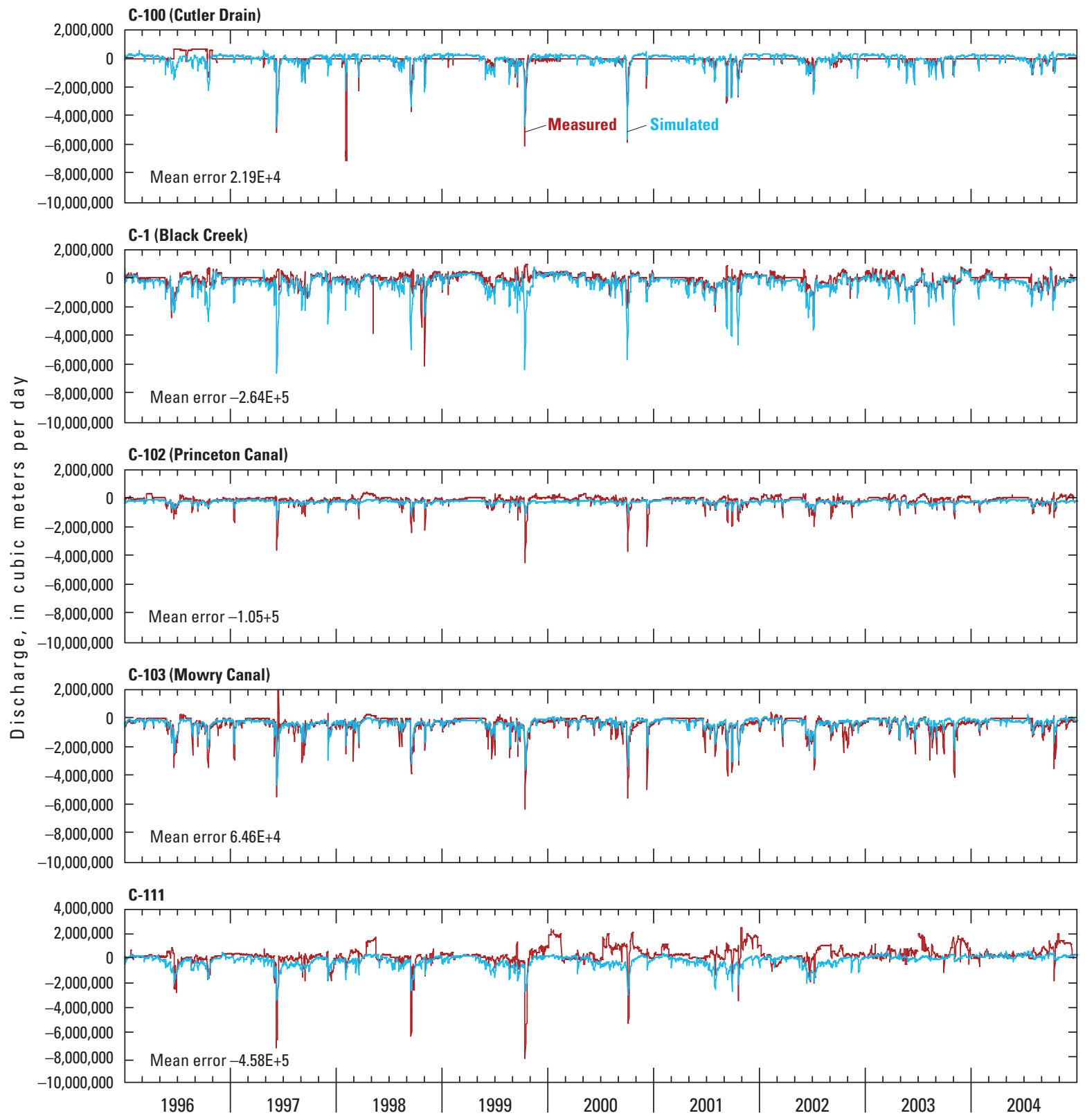

Figure 14. Simulated and measured daily canal base flow in designated drainage basins, 1996-2004. (Negative values represent flow from the aquifer. Site locations are shown in figure 13.).-Continued

Figure 15. Total simulated salt mass in the Biscayne aquifer, 1996-2004.

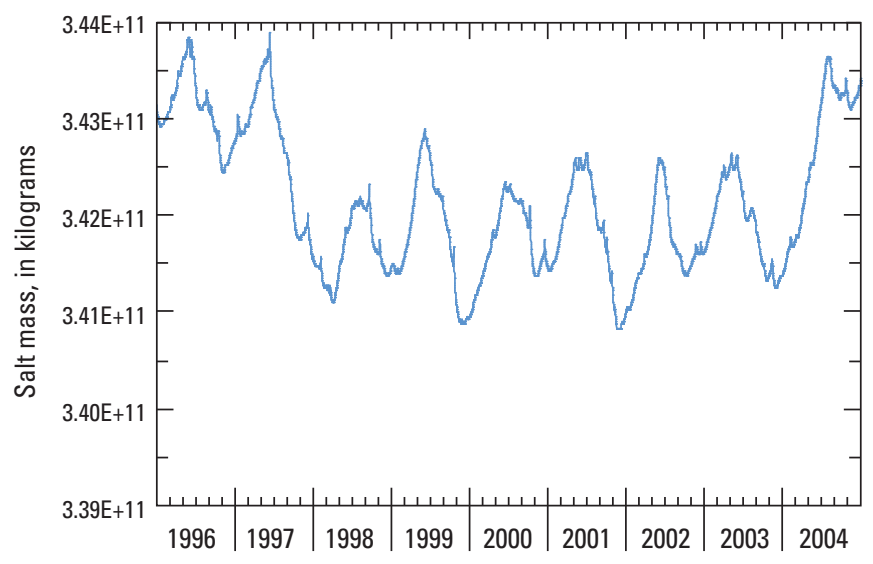




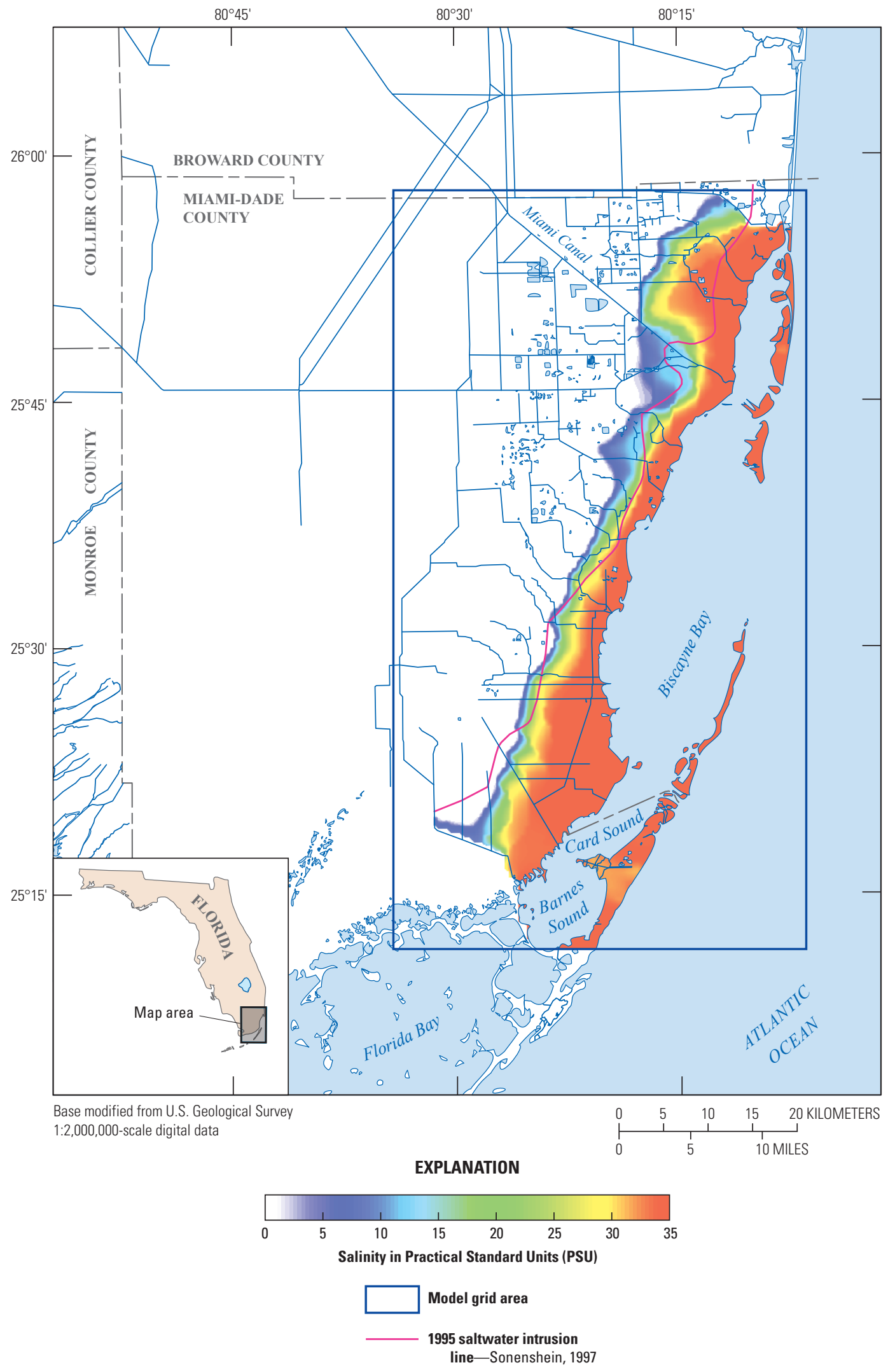

Figure 16. Simulated 2004 distribution of groundwater salinity at the base of the Biscayne aquifer, and the estimated extent of saltwater intrusion in 1995 (from Sonenshein, 1997). 


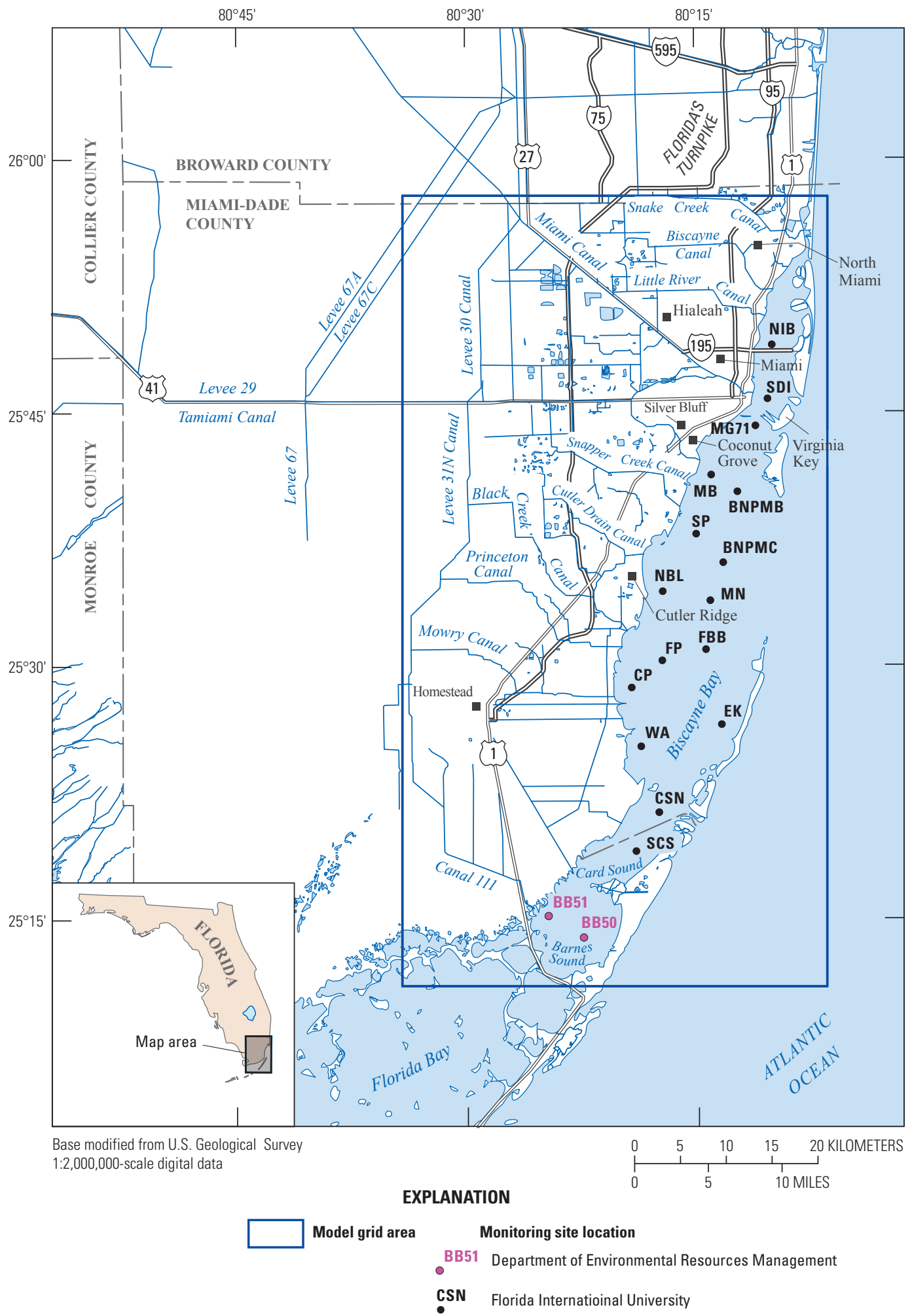

Figure 17. Location of salinity and temperature monitoring sites in Biscayne Bay. 


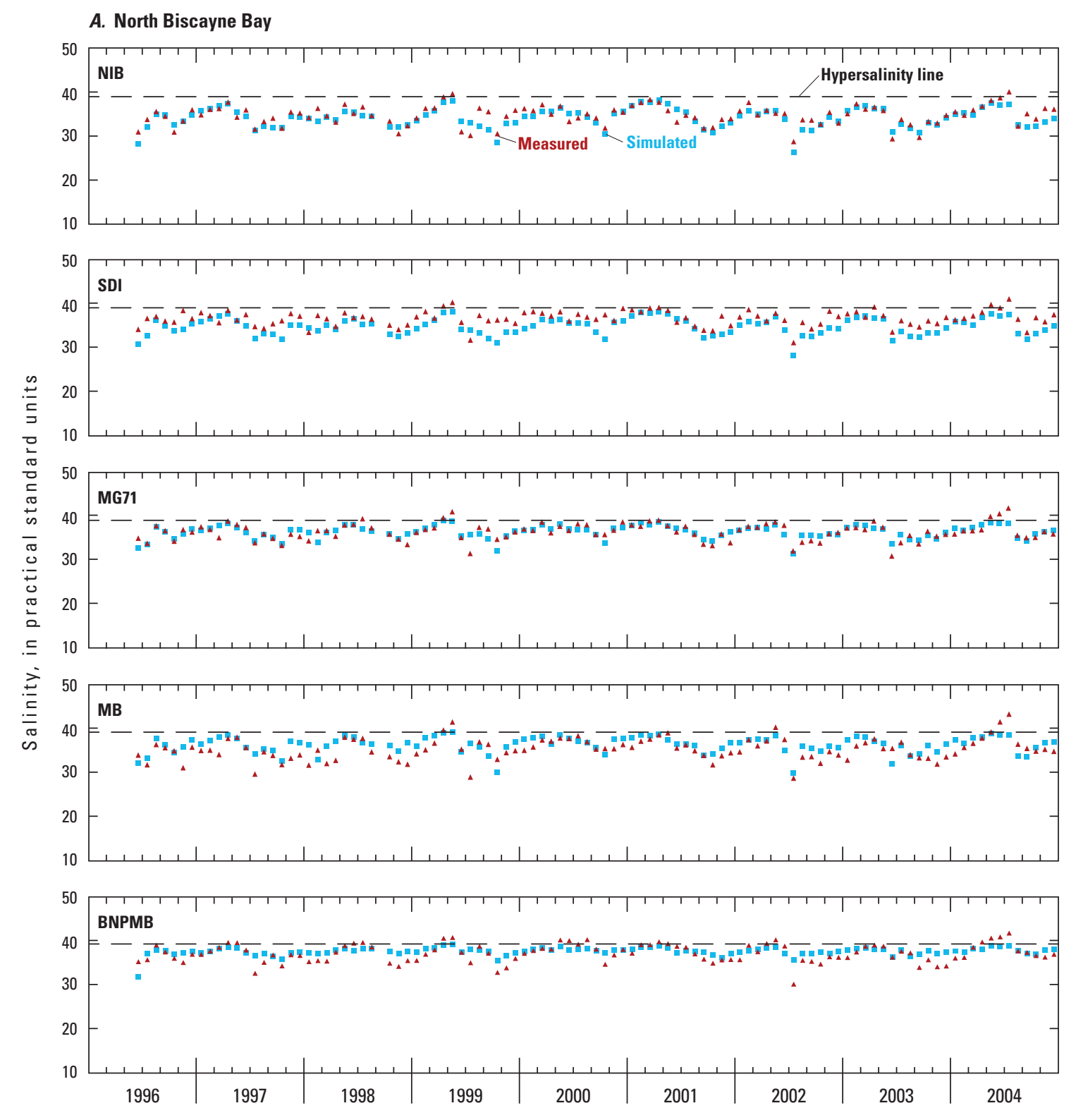

Figure 18. Simulated and vertically averaged surface-water salinity measured monthly in $(A)$ north, $(B)$ central, and $(C)$ south Biscayne Bay, and $(D)$ Barnes Sound (south Biscayne Bay), 1996-2004 (Site locations are shown in figure 17).

circulation observed in the main bay area. When pulses of freshwater enter the sound, they have a longer residence time; conversely, when no freshwater enters the system, the salinity can concentrate to higher levels. Under such a situation, small errors in the modeled connectivity of the sound to the ocean can create significant errors in the computed salinity.

Simulated salinity shows similar spatial distribution to observed salinity distribution. Simulated salinities are generally lower closer to canal discharge locations (figs. 17, 18, and 19), which agree with observed salinities at, for example, sites NIB, SDI, and MB (fig. 18A) and in Barnes Sound (fig. 18D). Simulated salinities are generally higher toward the middle of the bay, which agree with observed salinities at, for example, sites FBB, MN, and BNPMC (fig. 18B). Simulation results also show that, as with observed values, salinity in the middle of the bay is less seasonally variable, likely because of the proximity of an abundant source of relatively constant saline water (the Atlantic Ocean).

To ensure reasonable simulation of ET in Biscayne Bay (because it is not directly measured), simulated surface-water 


\section{B. Central Biscayne Bay}
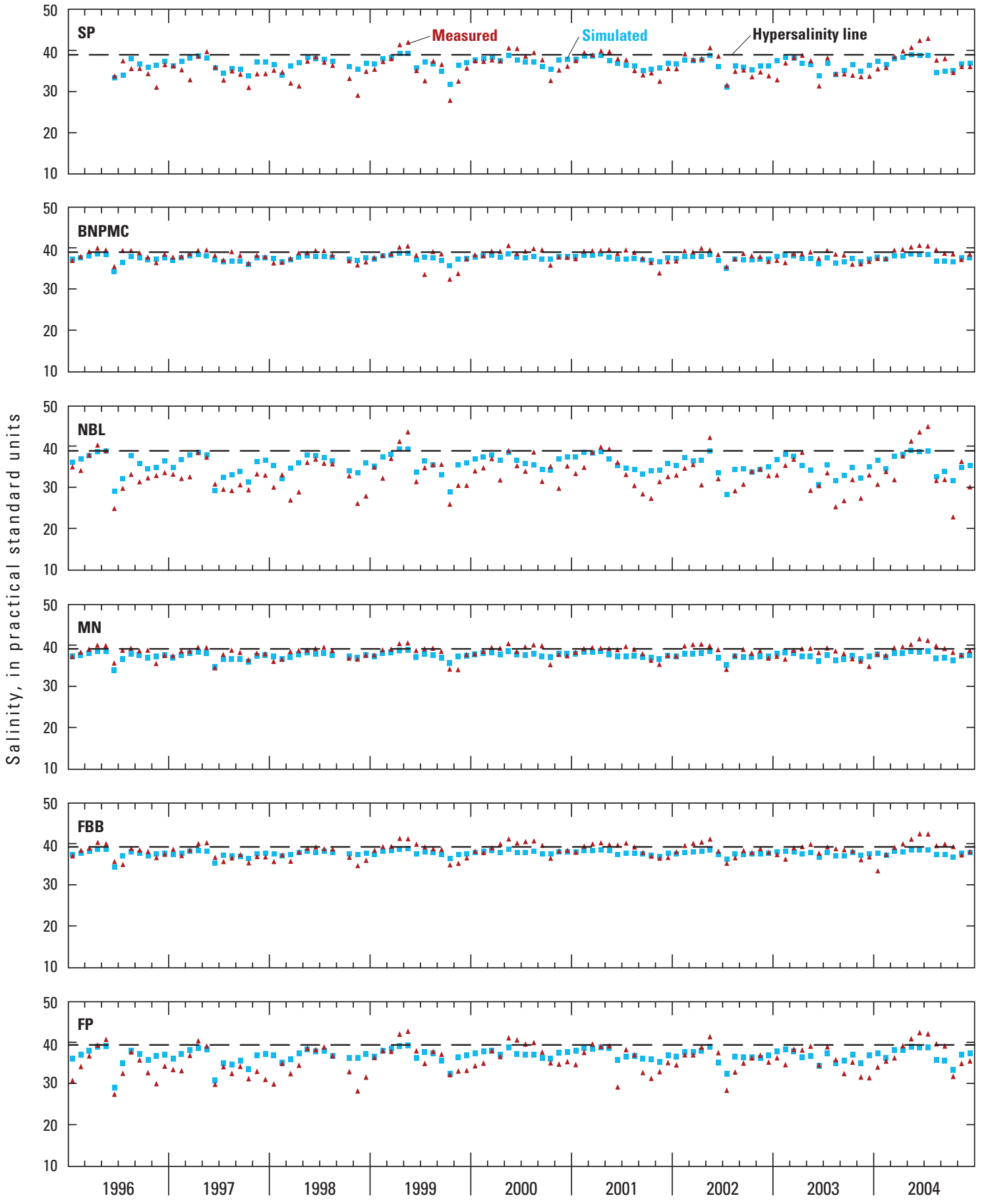

Figure 18. Simulated and vertically averaged surface-water salinity measured monthly in $(A)$ north, $(B)$ central, and $(C)$ south Biscayne Bay, and (D) Barnes Sound (south Biscayne Bay), 1996-2004 (Site locations are shown in figure 17).-Continued 


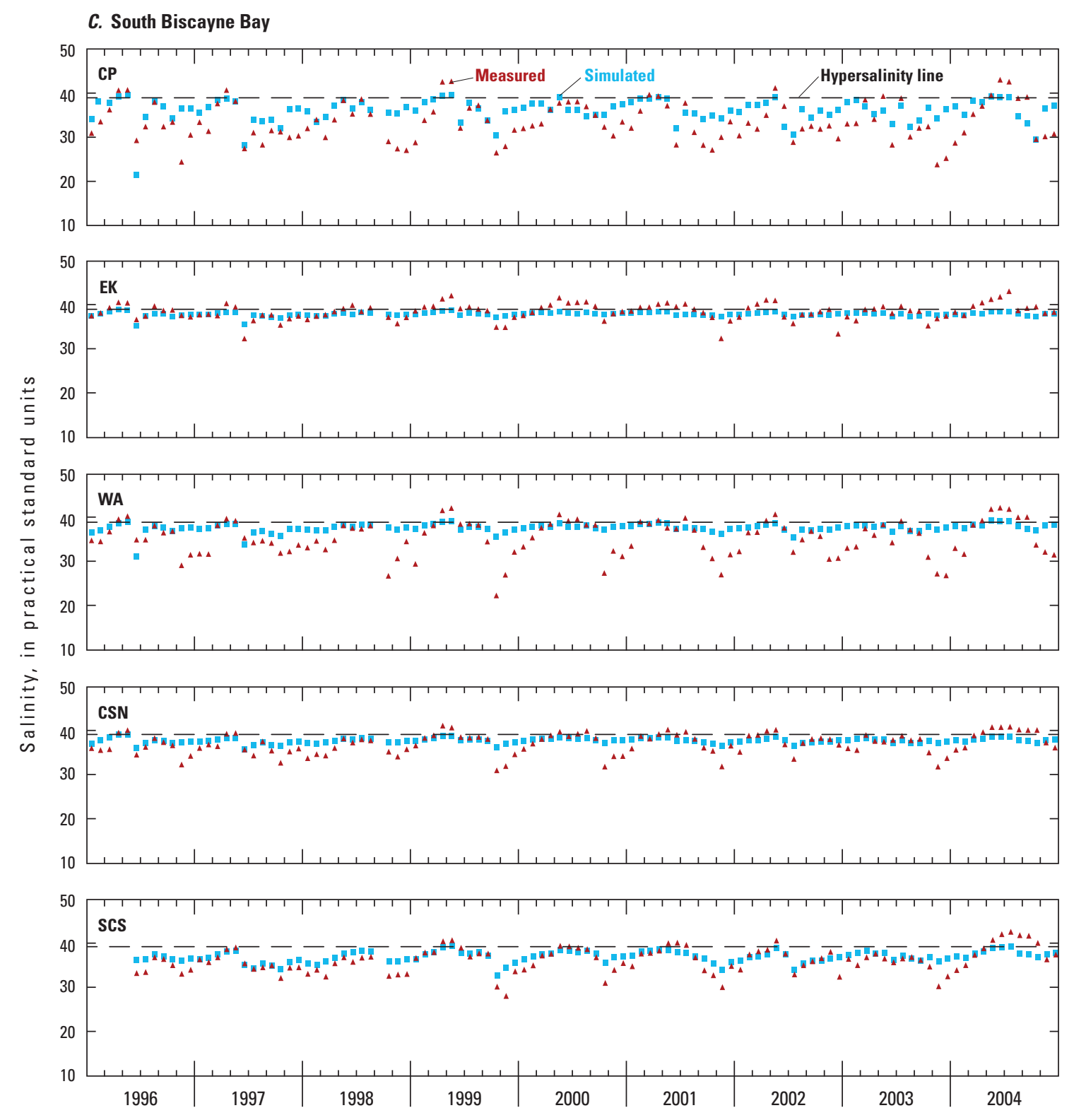

Figure 18. Simulated and vertically averaged surface-water salinity measured monthly in $(A)$ north, (B) central, and $(C)$ south Biscayne Bay, and (D) Barnes Sound (south Biscayne Bay), 1996-2004 (Site locations are shown in figure 17).-Continued 


\section{South Biscayne Bay, Barnes Sound}

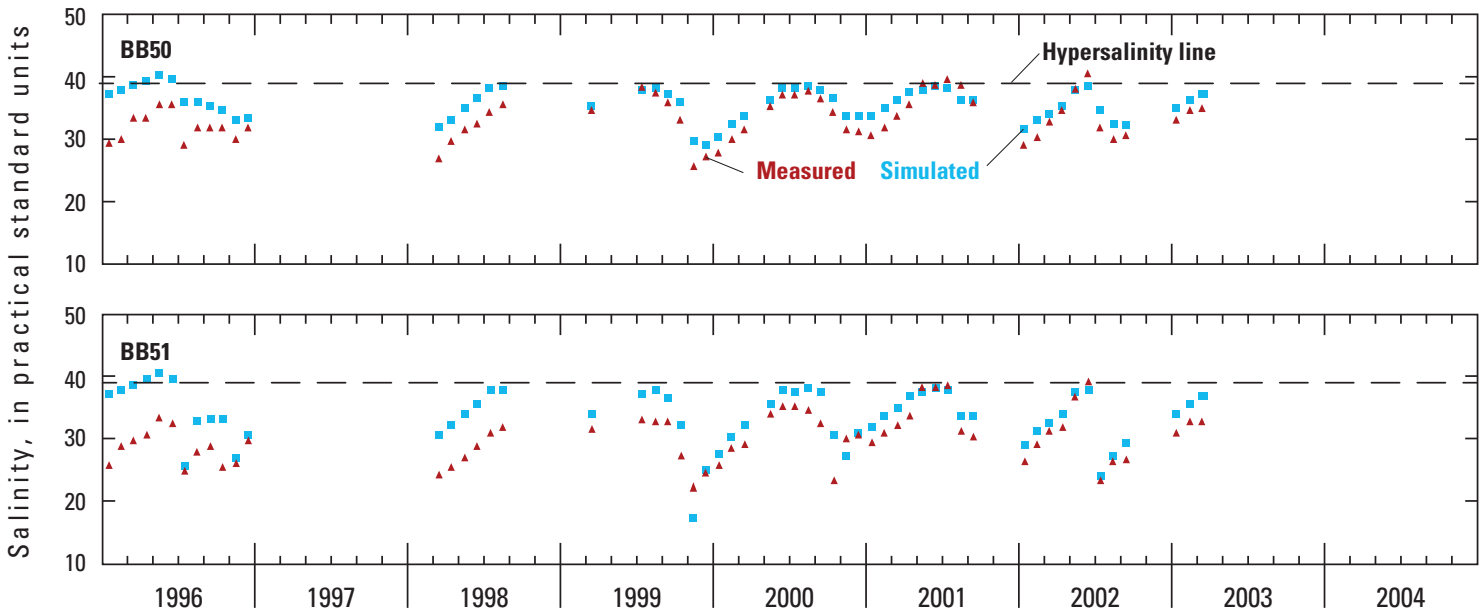

Figure 18. Simulated and vertically averaged surface-water salinity measured monthly in $(A)$ north, $(B)$ central, and $(C)$ south Biscayne Bay, and (D) Barnes Sound (south Biscayne Bay), 1996-2004 (Site locations are shown in figure 17).-Continued

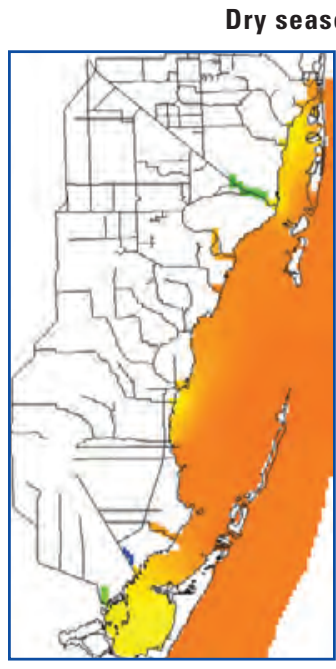

1/16/1997

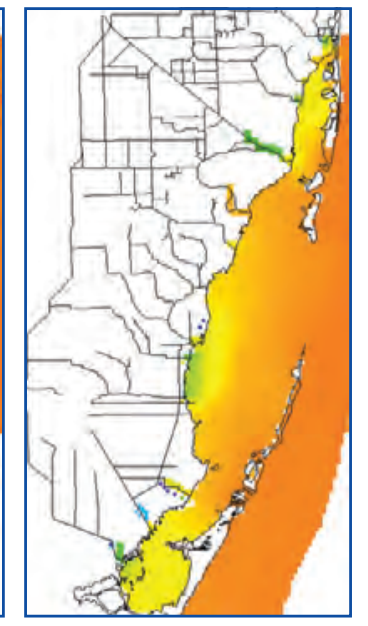

$1 / 16 / 2004$

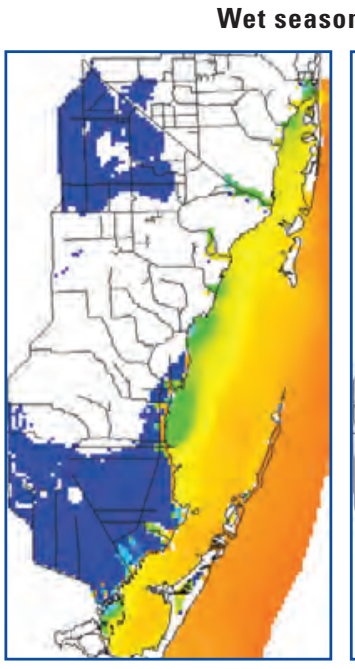

$6 / 10 / 1997$

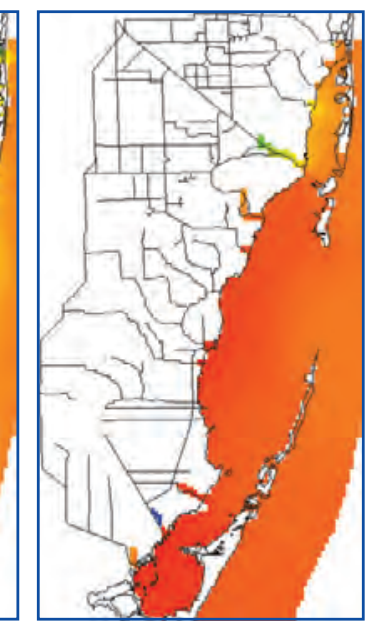

$6 / 10 / 2004$

EXPLANATION

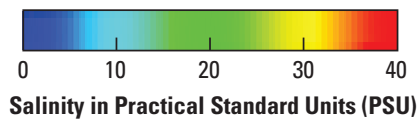

Model grid area

Figure 19. Simulated distribution of salinity in Biscayne Bay and inundated areas for dry season conditions in January of 1997 and 2004 and wet season conditions in June of 1997 and 2004. Rainfall for January 1997 and January 2004 equaled 9.1 centimeters ( 3.6 inches) and 4.6 centimeters (1.8 inches), respectively. Rainfall for June 1997 and June 2004 equaled 41.1 and 6.4 centimeters ( 16.2 and 2.5 inches), respectively.

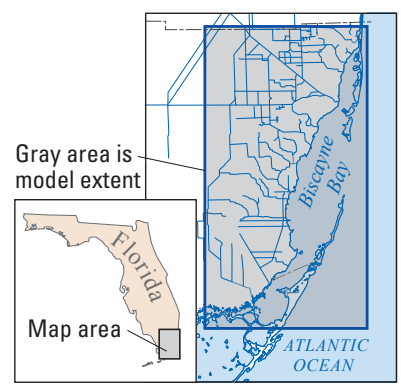


temperature in the bay was calibrated to match temperature derived from data collected at the 16 SERC monitoring stations (figs. 17 and 20). ET is largely a function of energy, or temperature, with more ET occurring during the warmer summer months and less occurring during the cooler winter months. Seasonal temperature patterns are similar to seasonal precipitation patterns with lower temperatures corresponding to the drier months and higher temperatures corresponding to the wetter months (figs. 20 and 21). Seasonal temperature range is more uniform, and the pattern is more consistent than that for salinity. The model consistently underestimates measured bay temperature values by an average of 1.7 degrees Celsius. This result most likely is caused by underestimation of the ET in the bay, which is based on measurements that are made overland that do not capture the unique metrological characteristics of an open water bay. Additional research and data collection of the ET parameters over the bay is needed to improve these results.

A. North Biscayne Bay
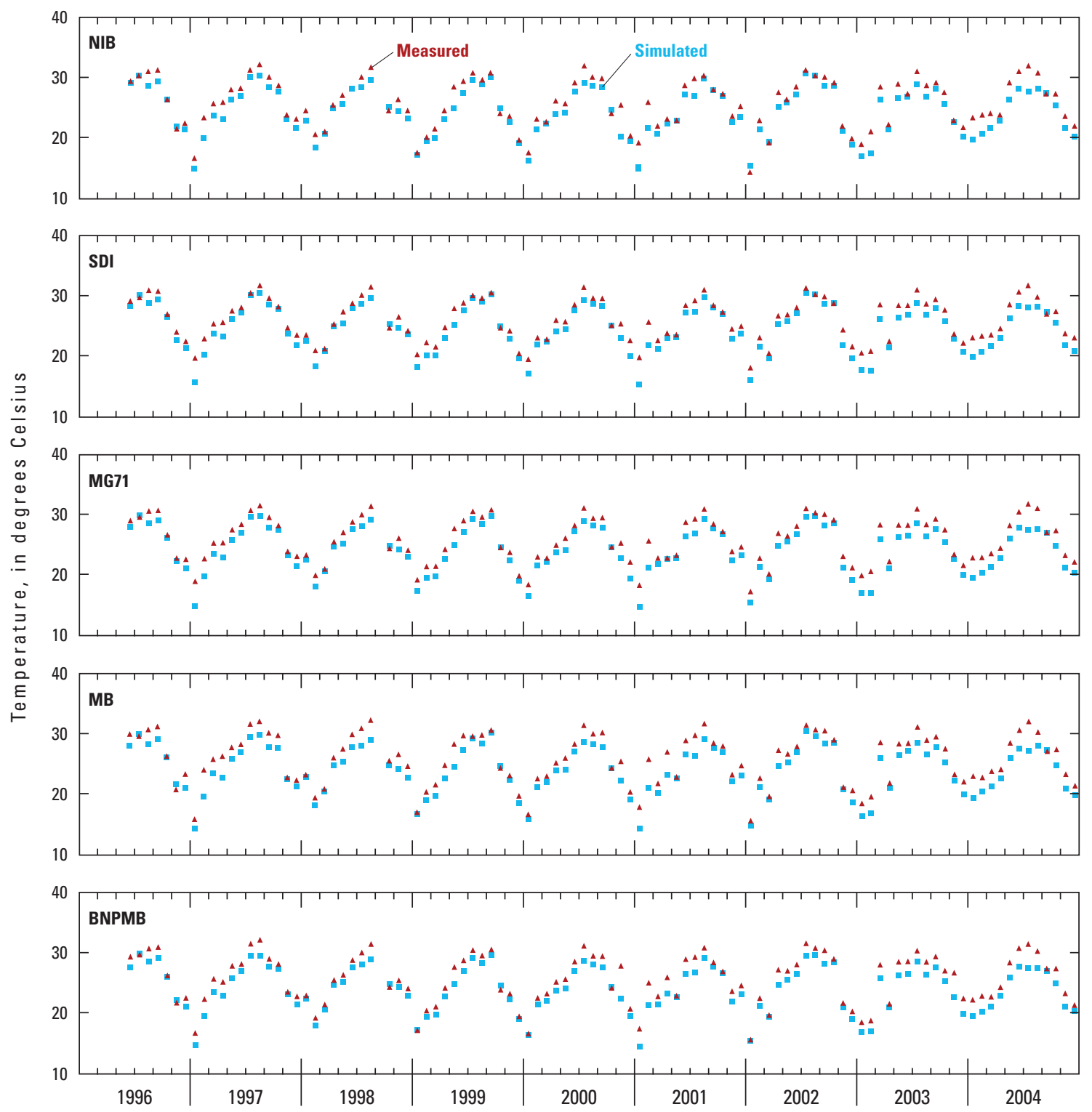

Figure 20. Simulated and vertically averaged surface-water temperature measured monthly in $(A)$ north, $(B)$ central, and $(C)$ south Biscayne Bay, 1996-2004 (Site locations are shown in figure 17). 


\section{B. Central Biscayne Bay}
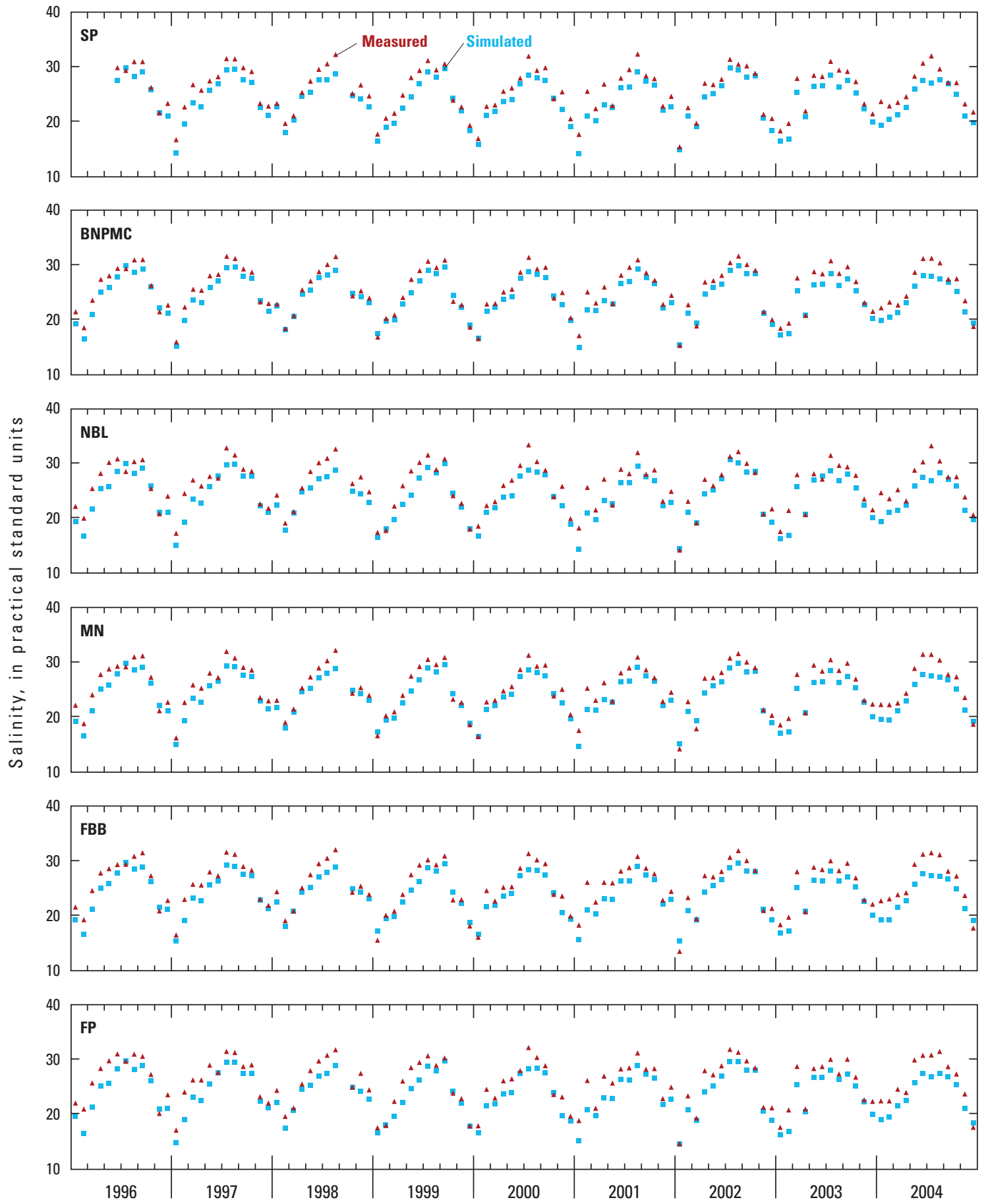

Figure 20. Simulated and vertically averaged surface-water temperature measured monthly in $(A)$ north, $(B)$ central, and $(C)$ south Biscayne Bay, 1996-2004 (Site locations are shown in figure 17).-Continued 
C. South Biscayne Bay
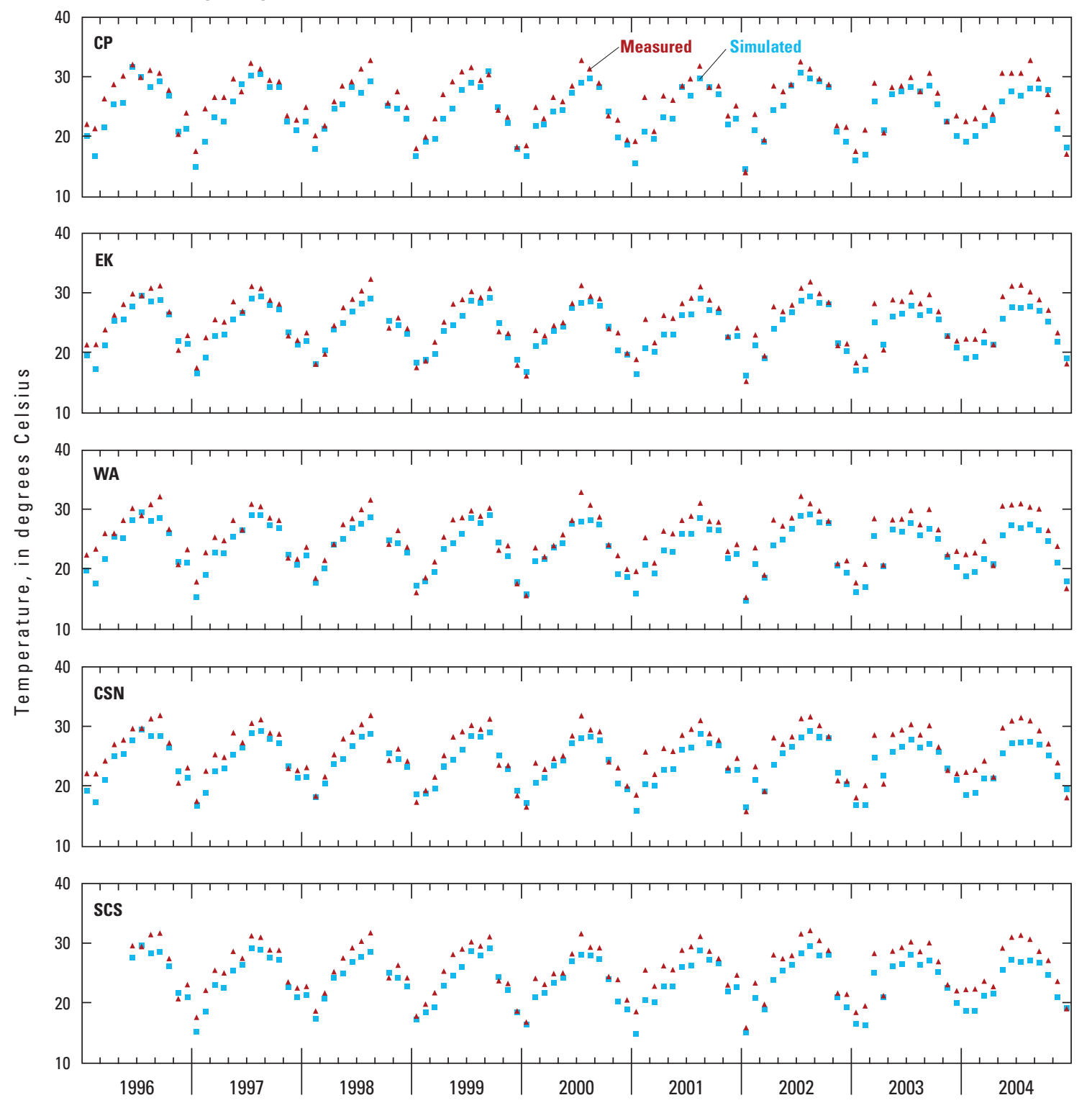

Figure 20. Simulated and vertically averaged surface-water temperature measured monthly in $(A)$ north, $(B)$ central, and $(C)$ south Biscayne Bay, 1996-2004 (Site locations are shown in figure 17).-Continued

\section{Quantification of Factors that Contribute to Biscayne Bay Salinity}

Flow budget calculations indicate that the largest component of flux into and out of the model area is provided by the tidal boundary, comprising about 99 percent of the water into and out of the model domain over the simulation period (table 7). Precipitation and surface-water flow at the coastal control structures account for most of the remaining 1 percent of flow into the system, with storage, the river (RIV) boundaries, and the GHB boundaries making up the remaining fraction of a percent. Surface-water ET and the RIV boundaries account for the larger part of the remaining 1 percent of flow out of the system, with storage, wells, groundwater ET, and the GHB boundaries making up the lesser part of the remaining flow out of the system. An overall 0.89 percent error exists on the mass balance, almost all of it attributed to excess surface water entering the simulated system. In particular, an excess of 3.0E10 cubic meters $\left(\mathrm{m}^{3}\right)$ enters the system from the tidal boundary, which accounts for about 63 percent of the imbalance. It is possible that the simulated ET or leakage processes may not be removing enough water from the system, accounting for most of the remainder of the imbalance.

Although input of flow at the coastal flow structures adds an additional $1.56 \mathrm{E} 10 \mathrm{~m}^{3}$ fluid to the system, which could account for 33 percent of the imbalance, these flows are measured and 
Dry season temperature

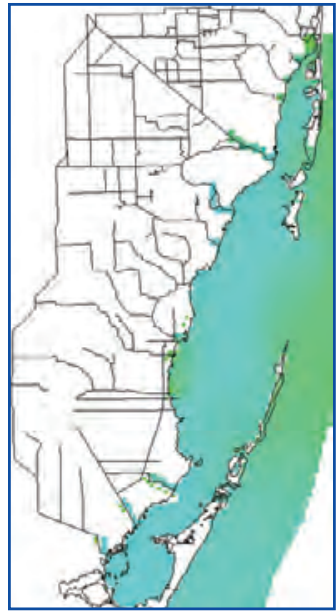

1/16/1997

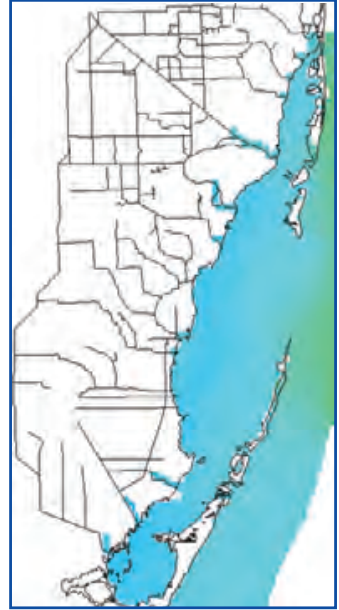

$1 / 16 / 2004$

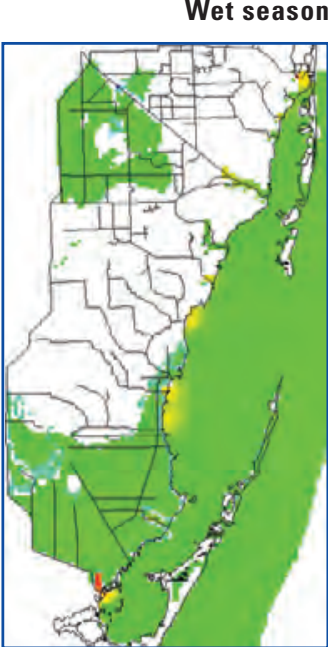

6/10/1997

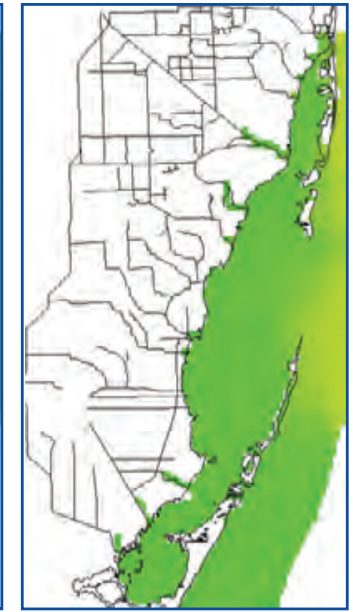

$6 / 10 / 2004$

EXPLANATION

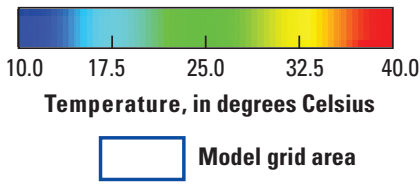

Figure 21. Simulated distribution of temperature in Biscayne Bay and inundated areas for dry season conditions in January of 1997 and 2004 and wet season conditions in June of 1997 and 2004.

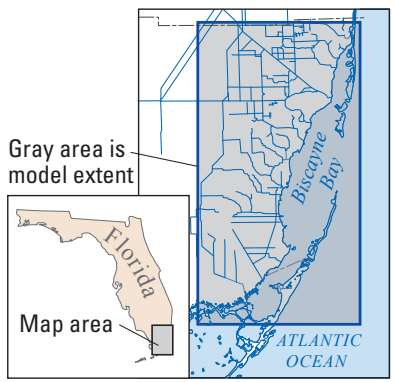

Table 7. Simulated water budget. Cumulative volumes of water in cubic meters for 9-year simulation period.

[ET, simulated volume lost by evapotranspiration process from the surface-water component of the model; GHB, volume lost or gained at general head boundaries of groundwater component of system; GW ET, simulated volume lost by evapotranspiration processes from the groundwater component of the system; \%, percent]

\begin{tabular}{|c|c|c|c|c|c|c|c|c|c|c|c|}
\hline \multicolumn{4}{|c|}{ Global budget } & \multicolumn{4}{|c|}{ Groundwater budget } & \multicolumn{4}{|c|}{ Surface-water budget } \\
\hline Rainfall & $3.950 \mathrm{E}+10$ & ET & $1.840 \mathrm{E}+10$ & Storage & $9.990 \mathrm{E}+9$ & Storage & $9.951 \mathrm{E}+9$ & Rainfall & $3.950 \mathrm{E}+10$ & ET & $1.838 \mathrm{E}+10$ \\
\hline Flow & $1.560 \mathrm{E}+10$ & GW ET & $3.795 \mathrm{E}+9$ & Leakage & $2.336 \mathrm{E}+10$ & Leakage & $4.713 \mathrm{E}+9$ & Flow & $1.560 \mathrm{E}+10$ & Tidal & $5.250 \mathrm{E}+12$ \\
\hline River & $6.129 \mathrm{E}+9$ & River & $1.572 \mathrm{E}+10$ & River & $6.129 \mathrm{E}+9$ & River & $1.572 \mathrm{E}+10$ & Leakage & $4.713 \mathrm{E}+9$ & Leakage & $2.336 \mathrm{E}+10$ \\
\hline GHB & $1.060 \mathrm{E}+9$ & GHB & $1.593 \mathrm{E}+9$ & GHB & $1.060 \mathrm{E}+9$ & GHB & $1.593 \mathrm{E}+9$ & Tidal & $5.279 \mathrm{E}+12$ & & \\
\hline Storage & $9.990 \mathrm{E}+9$ & Tidal & $5.250 \mathrm{E}+12$ & & & GW ET & $3.795 \mathrm{E}+9$ & & & & \\
\hline & & Storage & $9.951 \mathrm{E}+9$ & & & & & & & & \\
\hline
\end{tabular}


there is a much higher confidence in the accuracy of this value than the other budget components. The most likely source of the mass balance error is where the largest volume exchanges occur, such as at the tidal boundaries.

\section{Canal Flux into Biscayne Bay}

Surface-water flow into the system at the coastal control structures is the second largest input to the entire simulated system with the exception of tidal input (table 7). The flows that are measured at these control structures approximate the freshwater flows that discharge into the bay by way of the canal system. These flows fluctuate more than an order of magnitude seasonally (fig. 22). The smallest flows occur during the dry season when the canals are used to prevent saltwater intrusion by elevating freshwater heads onshore. The largest flows occur during the wet season when the canals are used to control onshore flooding (fig. 22). During the wet season, these flows contribute substantially to the dilution of Biscayne Bay. Furthermore, cumulative seasonal flows are largest when cumulative precipitation is largest. During the dry season, these flows approach the rates of groundwater fluxes into the bay and can be within the same order of magnitude.

\section{Groundwater Flux into Biscayne Bay}

Groundwater and Biscayne Bay surface water is exchanged on the nearshore bay floor. These fluxes are not easily measured, so models can be used to quantify them (for example, Langevin, 2001). Groundwater discharge is temporally similar to canal discharge, albeit at least an order of magnitude volumetrically smaller than canal discharge. Greater groundwater discharge occurs in the wet season and seasonal fluctuations are more subdued than canal discharge (fig. 22). Groundwater that discharges into Biscayne Bay may be fresh to saline in composition due to the effects of saltwater intrusion, and model simulation indicates that fresh groundwater discharge may represent a small fraction of total groundwater discharge to the bay. Saline groundwater is more likely to be discharged where the aquifer is more fully intruded by saltwater, for example along the southern part of the bay coast near Card Sound and Barnes Sound (fig. 16). Freshwater is more likely to be discharged where the aquifer is less fully intruded by saltwater, for example along the central part of the bay coast. Furthermore, groundwater/surfacewater exchange across the bay floor is spatially variable, with greater groundwater discharge along the northern portion of the landward side of the bay and tidal portions of the canals, and a slight amount of recharge occurring in the middle of the bay (fig. 23). Thus, although estimated to be a much smaller component of flux into Biscayne Bay than canal discharges, the contribution of groundwater discharge to Biscayne Bay salinity may have more influence in some areas, for example the southern parts of the Bay where the canal system is not as extensively developed or controlled as in the central and northern parts of the bay.

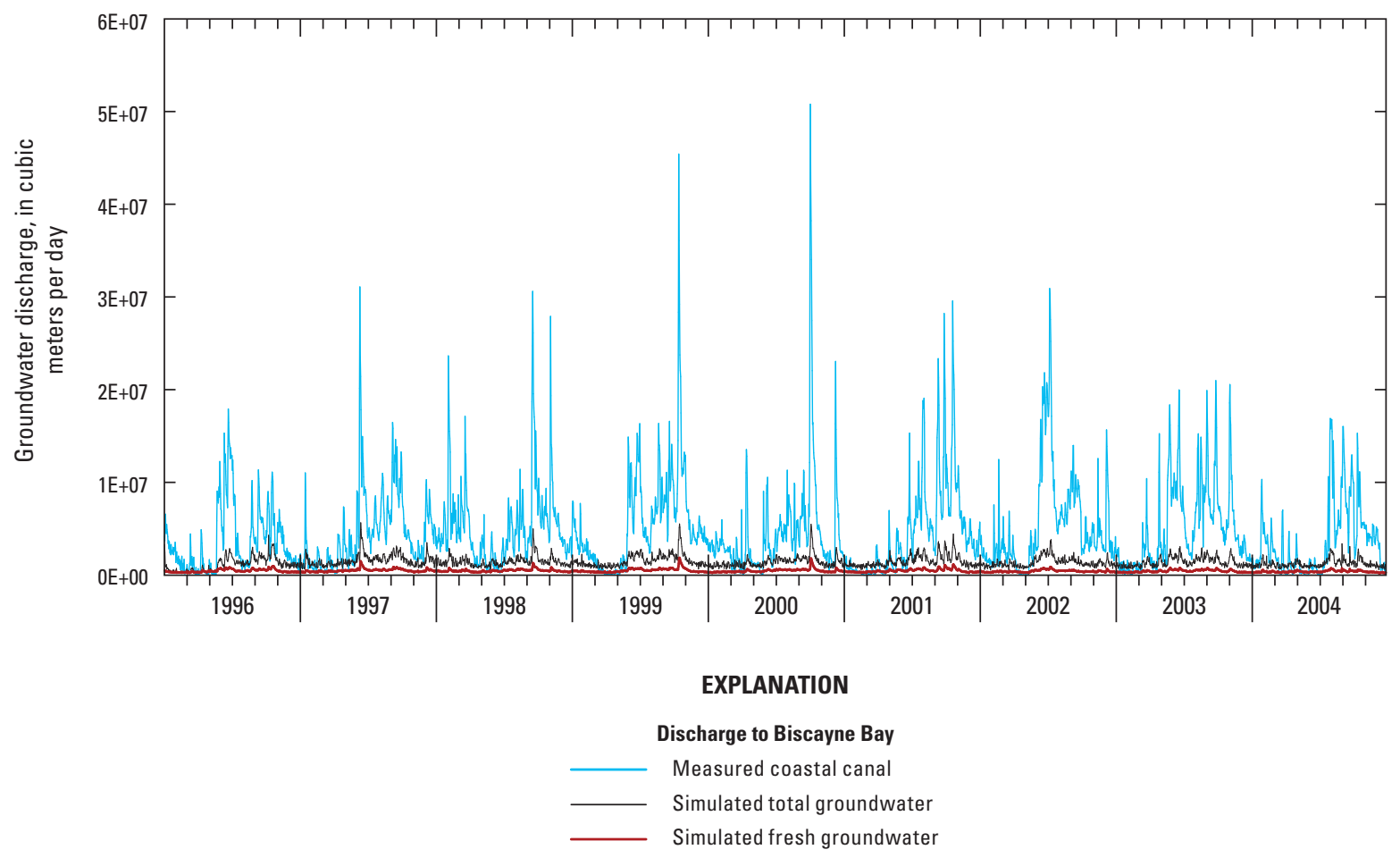

Figure 22. Simulated daily total and fresh groundwater discharge and measured daily canal discharge to Biscayne Bay, 1996-2004. 


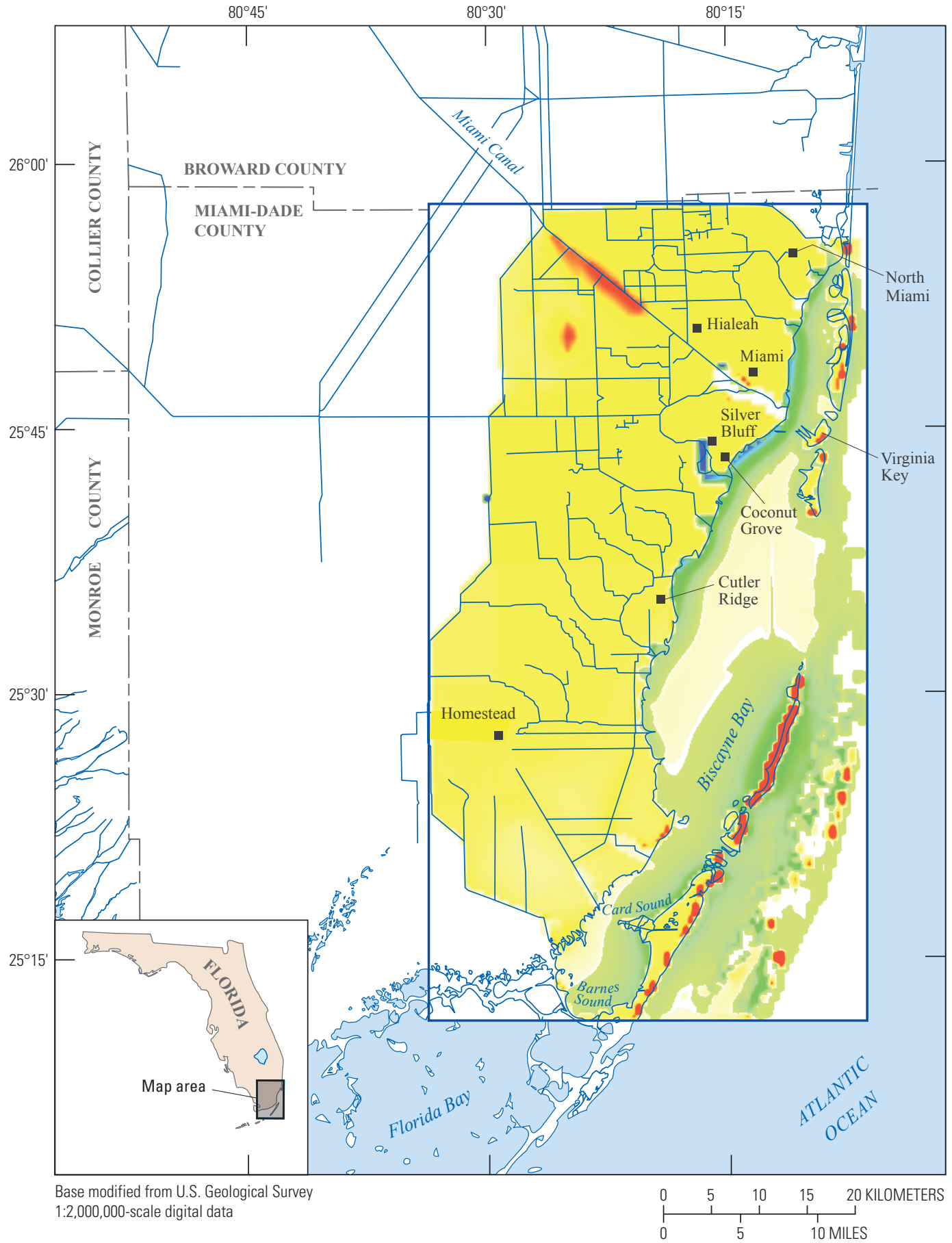

EXPLANATION

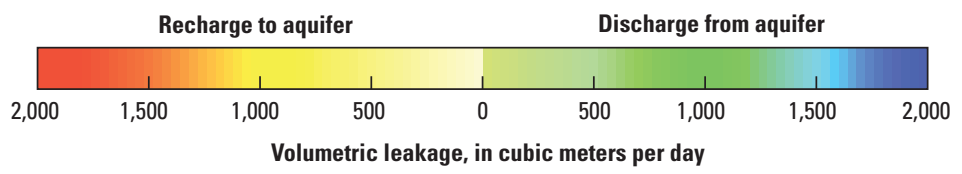

Model grid area

Figure 23. Distribution of simulated groundwater recharge and discharge in the model area, 1996-2004. 


\section{Evapotranspiration and Precipitation}

With the exception of tidal flux, precipitation and ET (largely ET over the bay) are the largest components of the hydrologic budget for the entire system (table 7). Approximately 90 percent of the $4,022 \mathrm{~km}^{2}$ model area is actively simulated at the surface where precipitation and ET enter and leave the model domain, with an average simulated precipitation of 121 centimeters per year $(\mathrm{cm} / \mathrm{yr})$. About 50 percent of the actively simulated surface of the model is over open bay water, and 50 percent is over predominantly urban land. The average ET for the entire actively simulated area is $67 \mathrm{~cm} / \mathrm{yr}$, which is the equivalent of more than 55 percent of total precipitation. The average ET for the bay is $113 \mathrm{~cm} / \mathrm{yr}$, which is about 93 percent of precipitation. Both ET and precipitation, however, are seasonally variable with larger fluxes during the wet season and smaller fluxes during the dry season. Assuming the wet season precipitation is 80 percent of the annual precipitation, wet season precipitation would account for $96.8 \mathrm{~cm}$, and dry season precipitation would account for $24.2 \mathrm{~cm}$. If wet season ET over the bay is 60 percent of the annual ET (based on data from German, 2000), wet season ET would account for $67.8 \mathrm{~cm}$, and dry season ET would account for $45.2 \mathrm{~cm}$. Accordingly, wet season ET from the bay is 70 percent of precipitation, and dry season ET from the bay is 187 percent of precipitation. Hence, the balance of precipitation and ET during the wet season would reduce bay salinity, whereas the balance of precipitation and ET during the dry season would increase bay salinity. During years when wet season precipitation is lower than average, for example less than 70 percent total precipitation for an average year, ET could outweigh precipitation over the bay for essentially the entire year.

\section{Hypersalinity Events}

Hypersalinity occurred in Biscayne Bay at various locations during dry periods throughout the study period. Hypersalinity is more prone to occur near the end of the dry season, during March, April, and May (fig. 18), because precipitation rates are generally lower (fig. 24). Canal discharge rates, which are strongly correlated to precipitation rates, are also generally lower (fig. 22) near the end of the dry season, and ET rates are higher than during the rest of the year. Ground-water discharge to the bay also fluctuates seasonally, although the rate of groundwater flux is likely too small to have more than a localized effect on bay salinity. Data indicate that the hypersalinity event in the spring of 2004 produced larger salinity values at more sites over a longer period of time than during the rest of the study period (fig. 18). Precipitation and canal discharge data (figs. 24 and 22) indicate that this hypersalinity event followed several years of relatively low precipitation and correspondingly reduced canal structure releases. Furthermore, the dry season conditions in 2004 were unusually extensive, continuing into July. Seasonal ET patterns, though similar to precipitation, are not affected by precipitation. Generally, losses to ET are less than freshwater gains during the typical wet season; however, when the onset of the wet season conditions are delayed or during particularly drier than normal wet season conditions, like that during 2004 , losses to ET are more likely to exceed freshwater input to the bay. Thus, hypersalinity is ultimately the result of a cumulative deficit of precipitation with a cascading effect on coastal outflows.
Figure 24. Total and seasonal precipitation rates for the simulation period, 1996-2004.

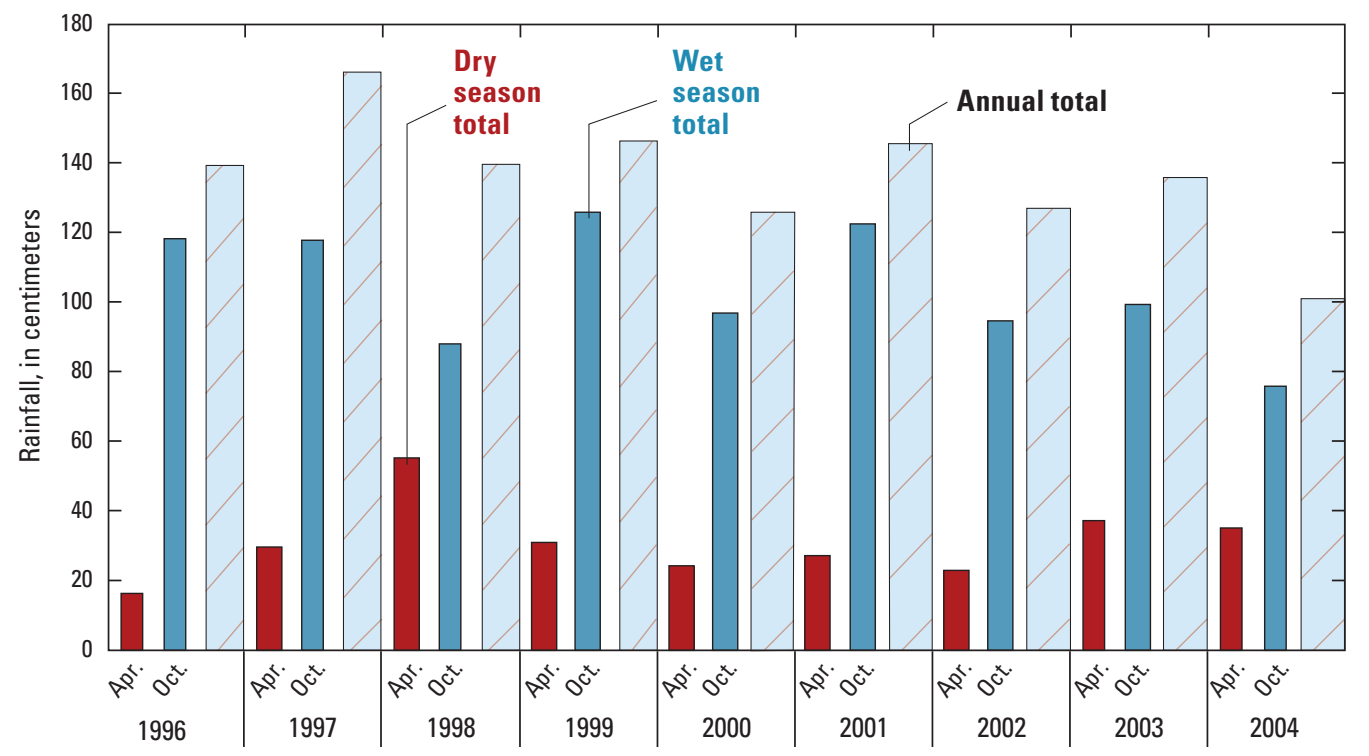




\section{Sensitivity Testing}

A sensitivity analysis was performed to evaluate the effects of boundary conditions and uncertainty in calibrated hydrologic parameter values on simulated groundwater levels, surface-water salinity, and groundwater discharges to Biscayne Bay. Five parameters considered to have high or unknown levels of uncertainty and a measureable effect on simulated results were tested: aquifer hydraulic conductivity, ET rates, leakage between groundwater and surface water, canal bed conductance, and the general head boundary condition.

Sensitivities were evaluated by comparing base case simulation results with output from each sensitivity simulation. Model output metrics used include: (1) the average ME, MAE, and RMSE for the groundwater observations (tables 6 and 8; fig. 25), (2) the difference between the simulated volume of groundwater discharged to the bay for the base case and each sensitivity simulation (table 6), and (3) simulated salinity in the northern part of the bay at site NIB and in the southern part of the bay at site BB50 (figs. $26 A$ and 27A).
Specifically, sensitivity test simulations were as follows:

- To test model sensitivity to aquifer hydraulic conductivity, three distributions were simulated: base case hydraulic conductivity was multiplied by two for every cell; base case hydraulic conductivity was multiplied by one-half for every cell; and a uniform value representing a spatial average over the model domain was applied to every cell.

- To test model sensitivity to ET, two distributions were simulated: values used for potential ET rate were multiplied by two and by one-half. These ET distributions do not translate directly into a doubling or halving of the calculated ET rate, because the ET rate is a function of the following: potential ET rate, extinction depth, and elevation of the ET surface for the groundwater component of the simulated system; and on air and water temperature, albedo, wind speed and direction, solar radiation, humidity, and the stomatic resistance of

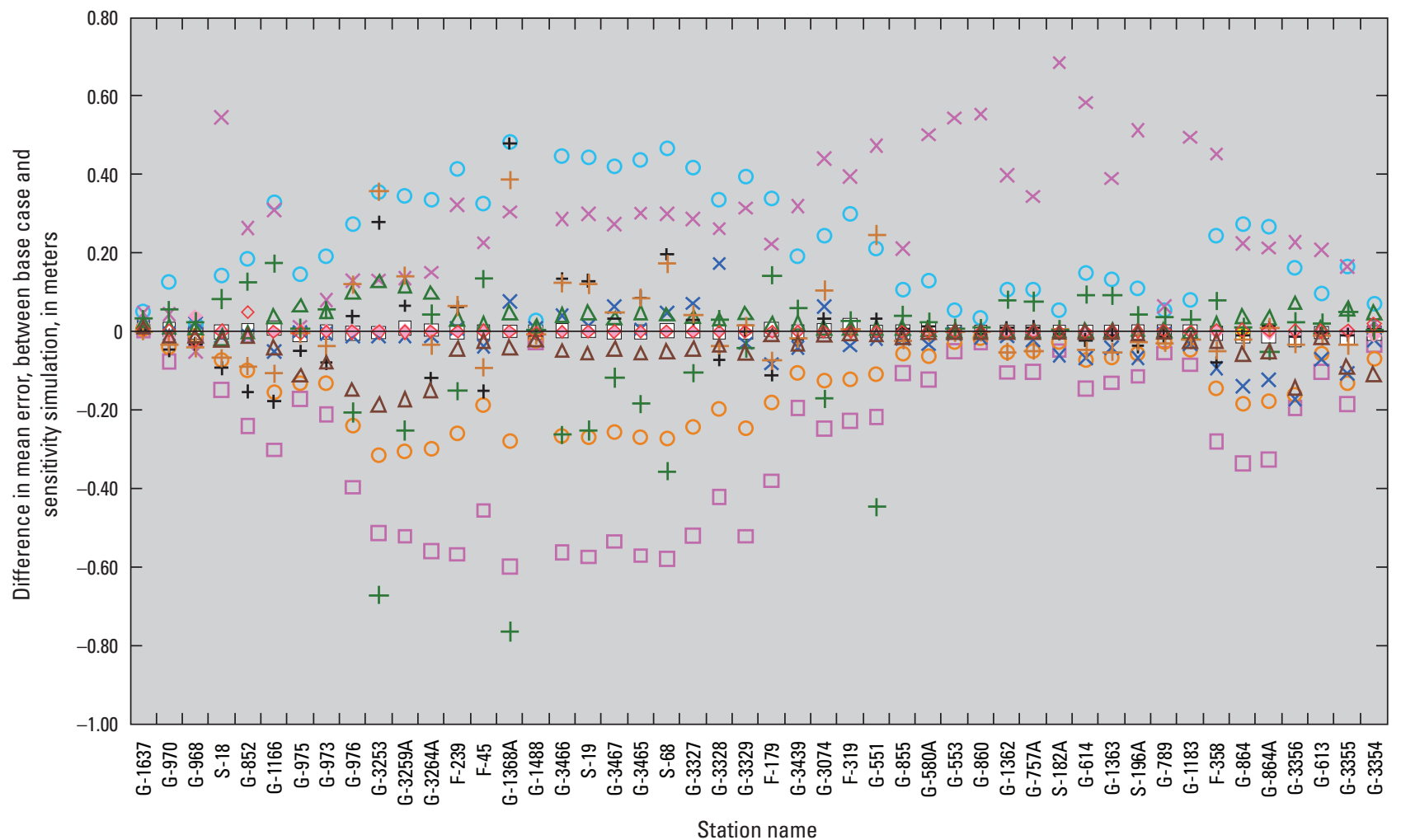

EXPLANATION

Sensitivity simulation

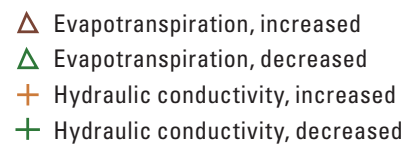

+ Hydraulic conductivity, uniform

$\checkmark$ Increased head at boundaries

$\square$ Leakage, reduced

Leakage, none

$\diamond$ No-flow boundaries

Figure 25. Difference in mean error, at each observation station, between the base case and selected sensitivity test simulations. 


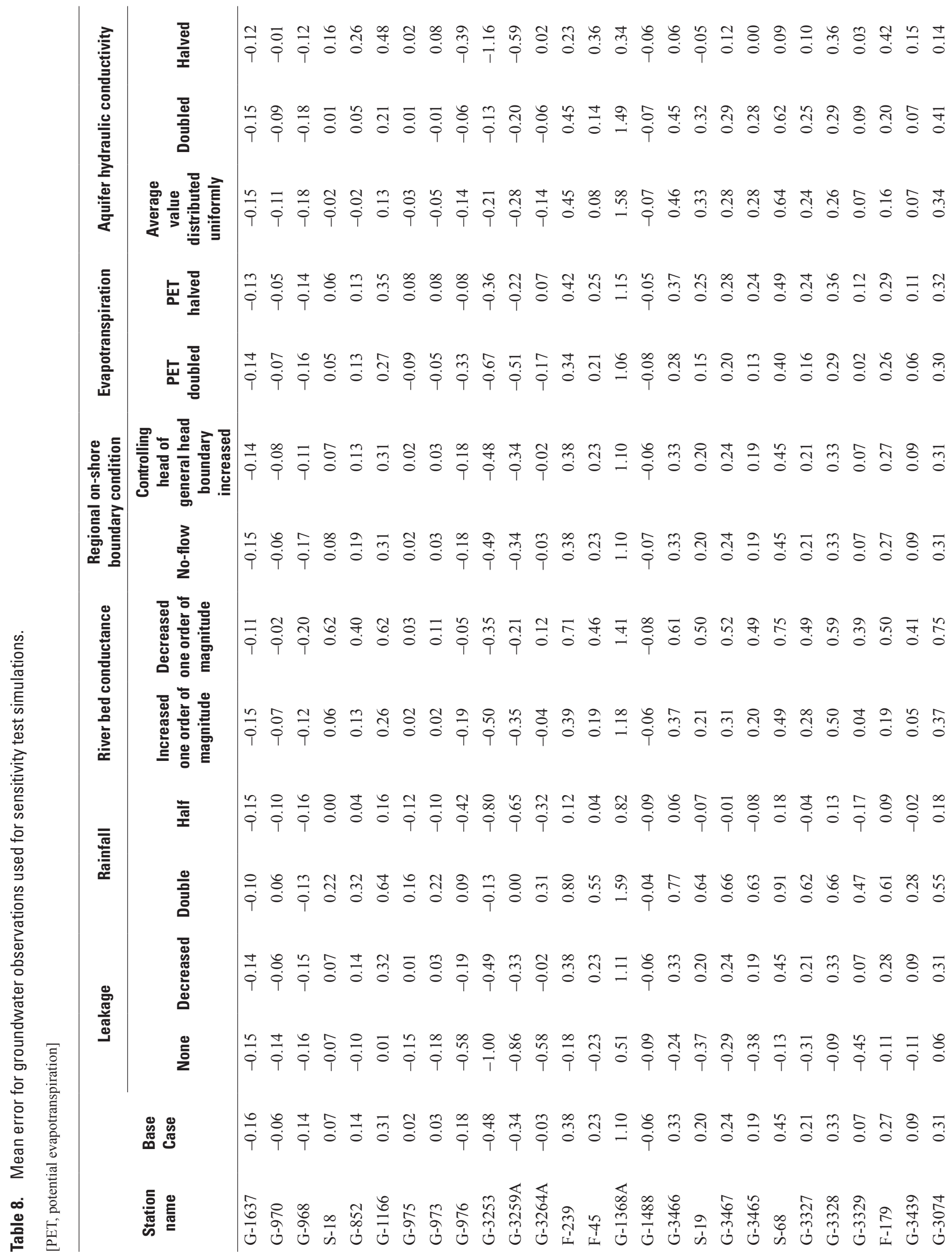




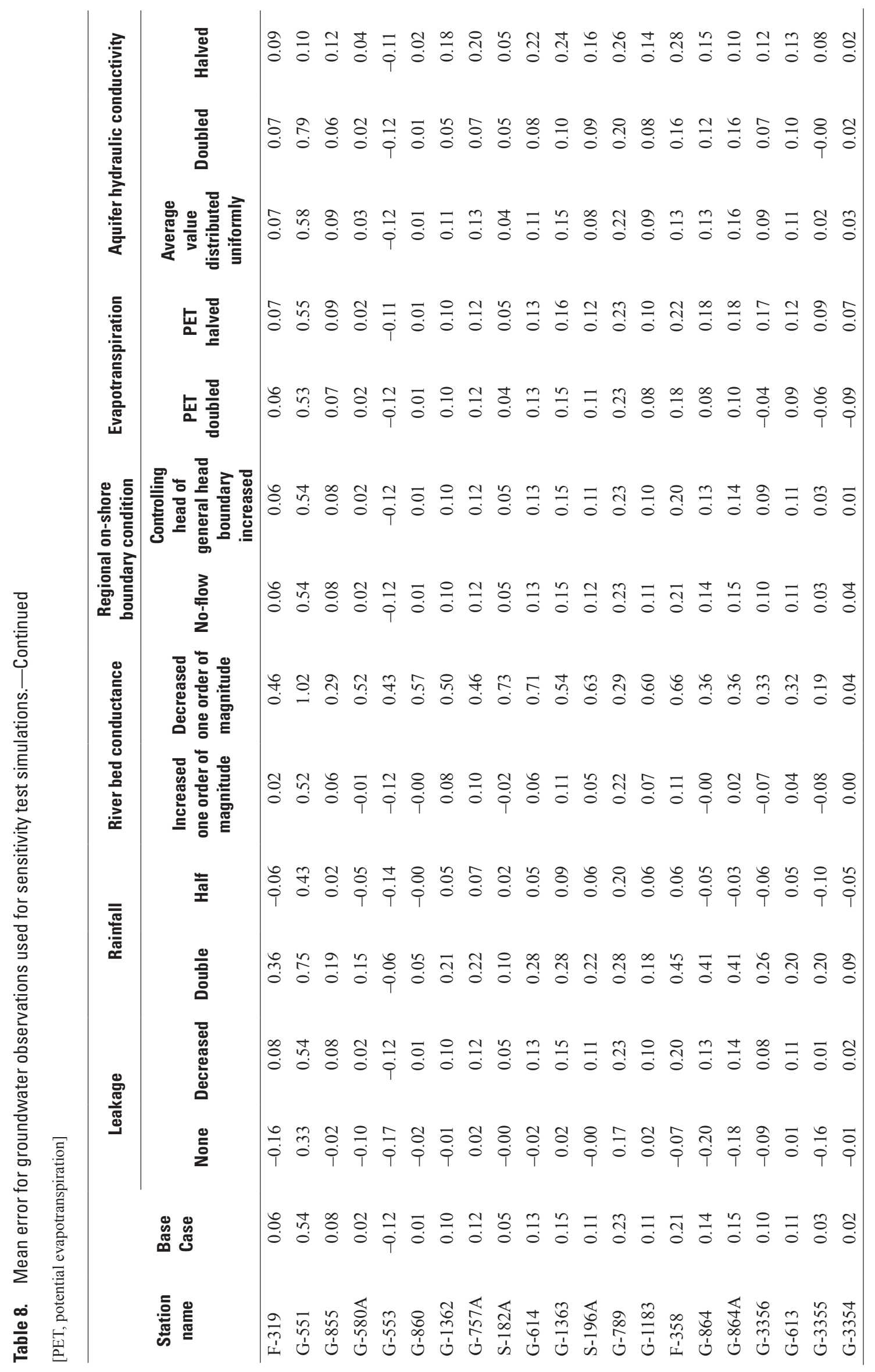



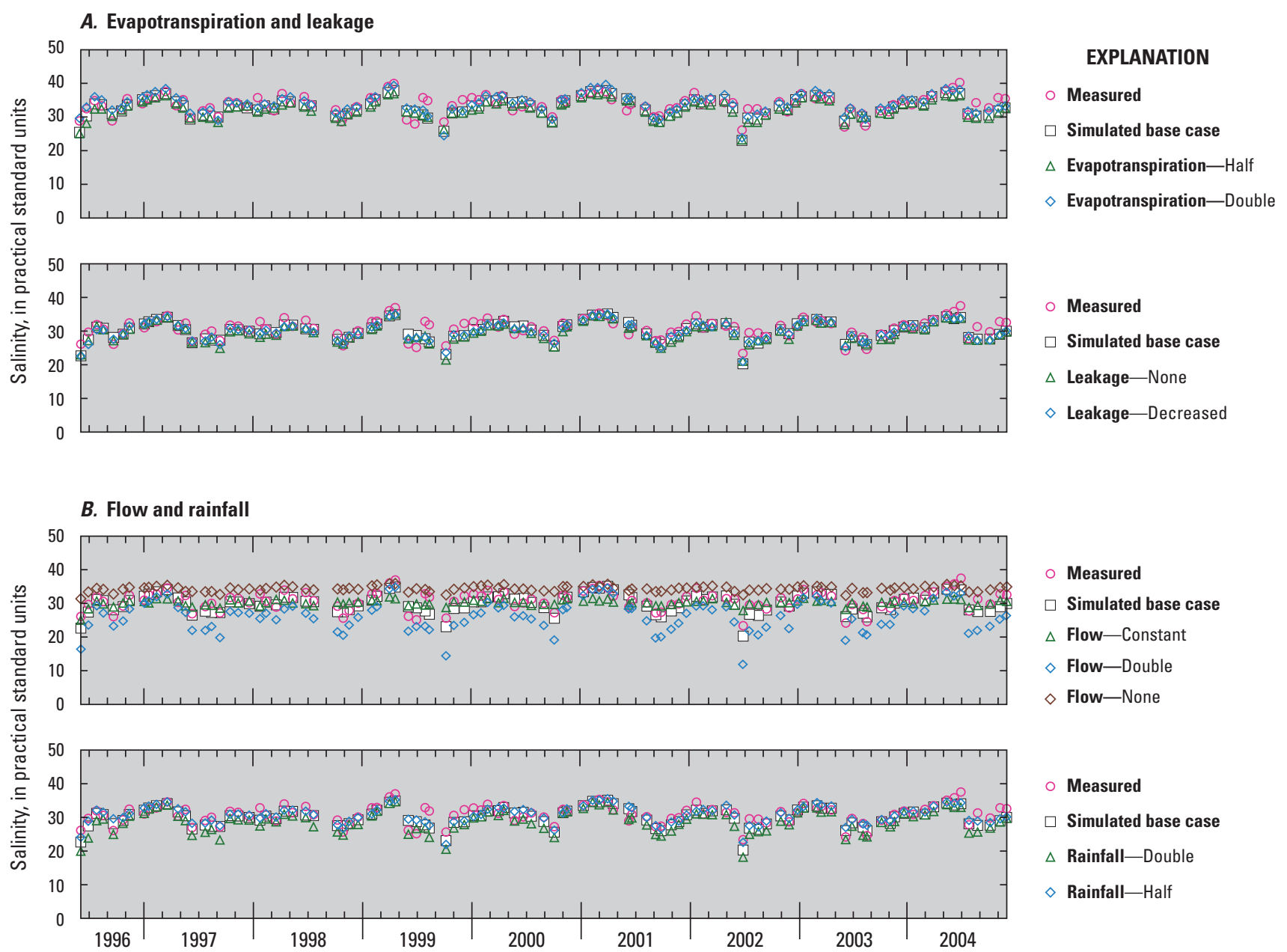

Figure 26. Response of salinity at site NIB in northern Biscayne Bay to simulated variations of $(A)$ evapotranspiration and leakage and $(B)$ flow and rainfall.

vascular plants for the surface-water component of the simulated system.

- To test model sensitivity to leakage between surface-water and groundwater systems, two leakage configurations were tested: for one test, leakage was reduced by decreasing the vertical conductivity of the transition layer by two orders of magnitude, and for the other test, all leakage was eliminated. The model is flagged to set all leakage to zero when the thin layer thickness is a negative value. Because leakage used in the base case model represents a maximum value, sensitivity of the model to increased leakage was not tested.

- To test model sensitivity to flux between the canals and the groundwater system, river conductance values were increased by an order of magnitude for one test and decreased by an order of magnitude for another test (except for reaches 58-60 because the base case values for these reaches were already low, and decreasing the values caused instabilities in the model).

- The general head boundary condition was tested by increasing the controlling head values (head values were multiplied by two and were thus twice as high relative to the datum) and by replacing the general head boundary condition with a no-flow boundary condition.

\section{Effects of Sensitivity Tests on Simulated Groundwater Heads}

To evaluate the sensitivity of simulated groundwater levels to model input, error statistics were calculated for the sensitivity test simulations and were compared with those for the base case simulation (tables 6 and 8; fig. 25). Divergence of an error statistic calculated for a sensitivity test simulation from that computed for the base case simulation indicates the degree of model sensitivity to the parameter tested. In general, 

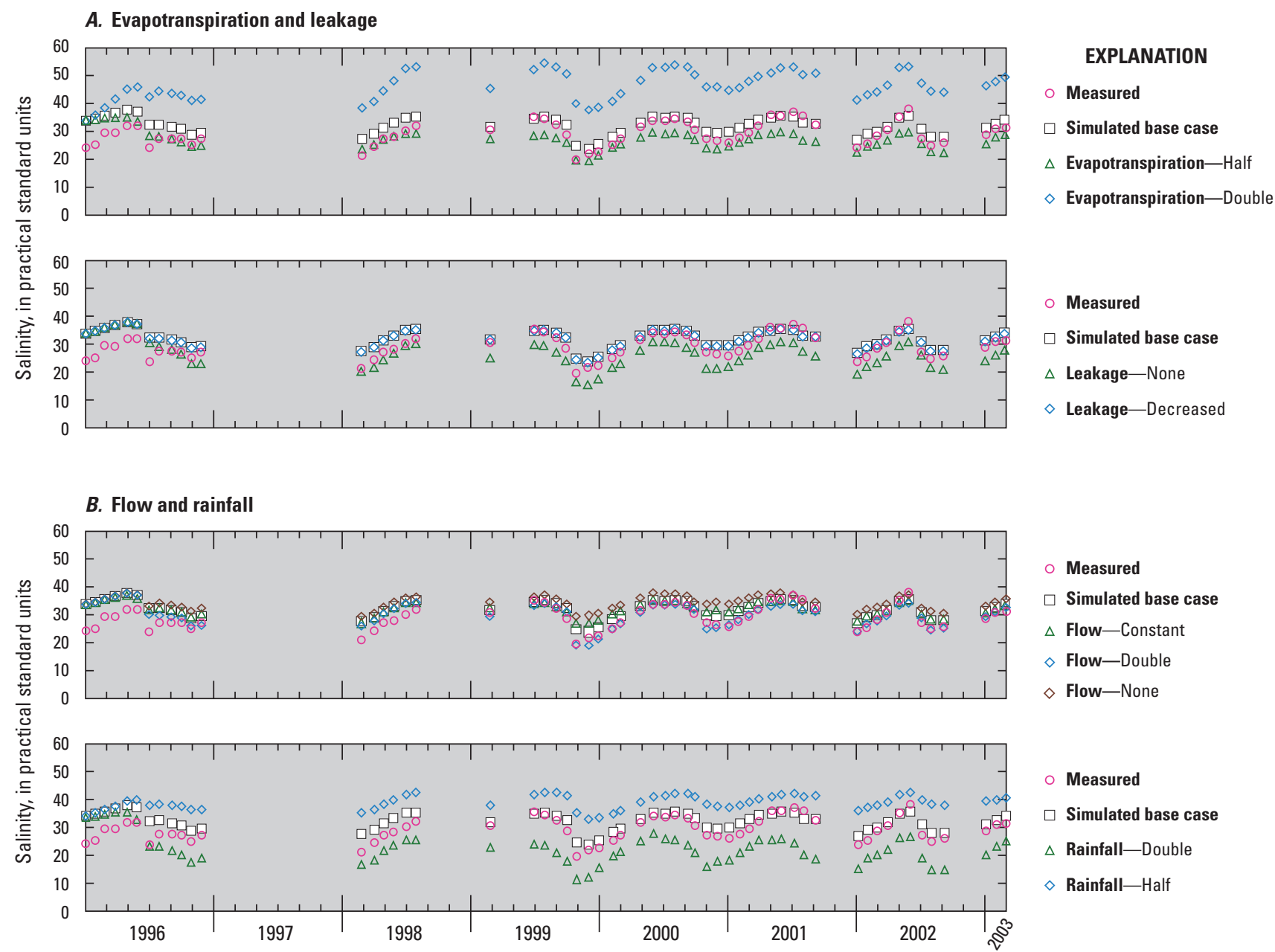

Figure 27. Response of salinity at site BB50 in southern Biscayne Bay to simulated variations of $(A)$ evapotranspiration and leakage and $(B)$ flow and rainfall.

simulated groundwater levels are most sensitive to decreasing river conductance and to elimination of the leakage between the surface-water and groundwater systems. Values of ME, MAE, and RMSE for all groundwater observations were significantly increased by decreasing river conductance. The value of ME was negative for all groundwater observations by eliminating leakage between the surface-water and groundwater systems, compared to the positive value for the base case simulation, even though MAE and RMSE differed little between the simulations. Simulated groundwater levels are also somewhat sensitive to aquifer hydraulic conductivity, as ME, MAE, and RMSE values for the sensitivity simulations diverge from those for the base case simulation, particularly for hydraulic conductivity reduced by half. Overall, simulated groundwater levels are apparently insensitive to changes in the general head boundary condition and to a reduction in leakage between surface-water and groundwater systems.

Similar to ME for the base case simulation, the sensitivity of simulated groundwater levels is spatially variable, as demonstrated graphically by the calculated difference between $\mathrm{ME}$ for the base case and for each sensitivity simulation at each observation location (fig. 25; table 8). The divergence between $\mathrm{ME}$ for the base case simulations and the sensitivity simulation for which leakage between the surface-water and groundwater systems is eliminated indicates that simulated groundwater levels are more sensitive to the implementation of leakage in the northern part of the model area north of Tamiami Canal (fig. 1) than in the southern part of the model area. Model sensitivity to other factors, including increased ET and hydraulic conductivity, is also greater in the northern part of the model area than in the southern part. The northern area of the model exhibits greater ME (fig. 10) for the base case simulation, likely because there are many production well fields and many of the groundwater observations are in close proximity to the well fields. In the southern part of the model area, particularly between Tamiami Canal and Homestead (fig. 1), sensitivity of simulated groundwater levels to decreased river conductance is higher than in other parts of the model area (fig. 25). For most observation locations, simulated groundwater levels are generally insensitive to modifications to the general head boundary condition and to reduction in leakage rate. 


\section{Effects of Sensitivity Tests on Groundwater Discharge to Biscayne Bay}

Although the flux of groundwater into the bay is substantially less than the canal flux and more difficult to quantify, it may have spatially localized influence on Biscayne Bay salinity, and under uncontrolled (for instance, predevelopment) conditions, it may be an important factor in controlling bay salinity. Furthermore, saltwater intrusion into the Biscayne aquifer from Biscayne Bay is of concern for water-resource supplies. In general, the simulated total groundwater discharge into the bay is most sensitive to changes in leakage between the surface-water and groundwater systems, with a 23-percent reduction in total groundwater flux with leakage conductivity reduced two orders of magnitude (table 6). All other factors affect groundwater fluxes by less than 10 percent relative to the base case. More important to bay salinity, the estimated fraction of groundwater discharge to the bay that is freshwater is more sensitive to the value and distribution of hydraulic conductivity than other factors that were tested. Doubling the hydraulic conductivity increased freshwater discharge to the bay by about 16 percent, and halving the hydraulic conductivity reduced freshwater discharge to the bay by about the same amount. Using a uniform distribution of hydraulic conductivity increased freshwater flux to the bay by almost 30 percent.

\section{Effects of Sensitivity Tests on Bay Salinity}

Simulated Biscayne Bay salinity showed discernable sensitivity only to ET and leakage between the surface-water and groundwater systems (figs. 26A and 27A), and the effects were more pronounced in the southern part of the bay (fig. 27A) than in the northern part (fig. 26A). In the southern part of the bay, doubling the ET resulted in a substantial increase in salinity, as much as $20 \mathrm{psu}$, whereas in the northern part of the bay, salinity increased slightly, generally within 2 psu. Halving the ET resulted in a decrease in salinity of more than 5 psu in the southern part of the bay but only a slight decrease in the northern part of the bay. The sensitivity of simulated salinity to changes in the leakage between the surface-water and groundwater systems is generally less pronounced than sensitivity to ET. Eliminating leakage resulted in a decrease in salinity of several practical salinity units in the southern part of the bay, whereas in the northern part of the bay, eliminating leakage resulted in a slight decrease in salinity. In both locations, a leakage reduction of two orders of magnitude had a negligible effect on salinity.

\section{Effects of Changes in Canal Flux and Precipitation on Biscayne Bay Salinity}

Canal discharge has a substantial effect on Biscayne Bay salinity, and the magnitude of the flux is largely controlled for saltwater intrusion or flood management purposes. Canal operations are likely to be modified to address future specific water-resource management needs or changes in hydrologic conditions. Future changes in canal operations may result in unintended effects on Biscayne Bay salinity. To test potential effects on Biscayne Bay salinity, a number of canal operation and discharge scenarios to the bay were tested for a 9-year period including: (1) no canal discharge; (2) canal discharge that was doubled; and (3) canal discharge that is uniformly applied temporally and spatially, representing the average flux over the 9-year simulation period of the base case. Remaining model input parameters used for these scenarios are the same as those used in the base case simulation.

Elimination of canal discharge resulted in high salinity conditions in the southern and northern parts of the bay compared to base case conditions (figs. $26 B$ and 27B). A reduction in freshwater input to the bay also served to increase salinity caused by ET and the encroachment of tidal marine waters. The effects are more pronounced in the northern part of the bay where managed canals are more numerous. The resulting seasonal pattern in the northern part of the bay is also more subdued than is simulated in the southern part of the bay and is also more subdued than is simulated for the base case. Conversely, increasing canal discharge two fold reduced salinity in both the southern and northern parts of the bay when compared with the base case. Similar to the effects of eliminating canal flux, the effects of doubling canal flux are more pronounced in the northern part of the bay than in the southern part of the bay. Seasonal fluctuations in the northern part of the bay are enhanced by the two-fold increase in discharge. The consequence of increased flow is more subdued in the southern part of the bay. Setting uniform canal fluxes resulted in little change in the southern part of the bay and resulted in a more subdued fluctuation in the northern part of the bay compared with the base case simulation. Elimination of canal outflows would have potentially severe ecological impacts, but the double canal discharge case could also have negative repercussions as flora and fauna in the area are sensitive to rapid fluctuations in the salinity values. There is also a potential for greatly increased canal discharges to transport harmful contaminants into the bay.

Precipitation plays an important role in controlling Biscayne Bay salinity, both directly in parts of the bay where canal discharge is more limited (the southern part of the bay) and indirectly in affecting the release of water from the canal control structures as well as fresh groundwater discharge. Precipitation varies temporally, both on a seasonal and annual basis (this is shown in the report). Decadal and multi-decadal changes in precipitation could affect Biscayne Bay salinity directly or indirectly. In two sensitivity scenarios precipitation was doubled and halved as examples of potential extreme conditions over the next few decades, to examine the effects on Biscayne Bay salinity.

In contrast to changes in canal flux, the effects of changing precipitation are greater in the southern part of Biscayne Bay than in the northern part (figs. $27 B$ and 26B). Doubling precipitation resulted in a reduction of bay salinity 
as much as 15 psu in the southern part of the bay and a slight enhancement of seasonal fluctuation relative to the base case simulation (fig. 27B). Reducing precipitation by half resulted in an increase in bay salinity in the southern part of the bay as much as 10 psu and a slightly subdued seasonal fluctuation relative to the base case simulation. In the northern part of the bay, the effects are similar but having a much smaller magnitude (fig. 26B).

\section{Model Limitations}

As for all numerical models of hydrologic systems, simulated conditions should be interpreted with a consideration of the limitations of the model. Such models incorporate educated assumptions about processes that are important to simulate the system and answer specific questions, use and interpret a variety of data to physically describe the system and check model accuracy, and require information about how the model domain interacts with the surrounding hydrologic system. These assumptions and interpretations limit the accuracy of the model to represent current hydrologic conditions and limit the ability of the model to predict future or other conditions that diverge from those for which the model was calibrated. The model is thus inherently limited by conceptualization of the hydrologic system, model construction (including physical properties used to describe the system, boundary conditions, and spatial and temporal averaging of discretization parameters), and uncertainty in "observations" that are used to calibrate the model. Some of these limitations are explicitly demonstrated in the fit of the model to the observed system, and others are more conceptual in nature. The following discussion of model limitations is not intended to reduce the value of the model for its intended or other relevant purposes or to highlight its flaws, rather it is intended to illustrate further how the model works and acknowledge that its application, like that of all models, is limited in the degree of certainty to which it can be used to answer specific questions.

For the surface-water component of the model, canals are represented both implicitly, as boundary conditions for the groundwater component of the model, and explicitly, as measured fluxes input at the coastal structures. This canal representation allows accurate input of freshwater into Biscayne Bay, which supports the primary model objective of simulating the changing salinity in the bay but requires calibration of the model upstream from the coastal structures to estimated "base flows" or recharge/discharge rates between the aquifer and the canal. Where the canals are implicitly represented, the model requires a hydraulic conductance value for the interface, or canal bed, between the aquifer and the canal. Such values are difficult to measure in the field and are parameterized by matching simulated flux between the aquifer and canal to an observed "base flow" or gain or loss in the canal. For this model, the observed base flow is estimated by subtracting discharge through canal structures that define the downstream extent from the upstream extent of designated canal basins. These estimates are highly uncertain because of the abundance of secondary and tertiary drainage features and canals that are not measured that feed into the main simulated canals. Furthermore, overland flow, which may also directly or indirectly feed into canals and affect the estimated value of base flow, is only accounted for in the minority of cells that are designated as wetlands. Finally, the different temporal discretization of the groundwater and surface-water components of the model resulted in a lag in groundwater response to changes in the hydrologic system relative to the surface-water response. Thus, abrupt changes in canal flux, which occur over a sub-day time scale, could not be captured by the daily time scale of the simulated groundwater discharge or recharge from the canal system. So the calibration target for exchange between the canal system and the aquifer has a considerable amount of uncertainty associated with it. Accordingly, the main objective during model calibration was to represent the dominant direction of flow between the aquifer and the canal, and the magnitude of the flow rate, rather than closely match the observed base-flow rates. Sensitivity tests indicate that simulated groundwater heads are highly sensitive to canal bed hydraulic conductance.

The transitional layer represents the shallowest part of the groundwater system in onshore areas through which precipitation recharges the aquifer system directly. In the model, precipitation that occurs in most model cells and not lost to the system by ET, infiltrates the transitional layer into the aquifer as a function of its estimated hydraulic conductivity. Some precipitation that falls onto land surface does not recharge the aquifer directly and is instead redirected through overland flow into the surface-water drainage system. The assumed value for hydraulic conductivity was set to allow minimal resistance because the model does not account for overland flow. Although there is some resistance to direct aquifer recharge and field observations indicate that overland flow frequently occurs in some areas during precipitation events, the simulated groundwater levels are not sensitive to a two-order of magnitude reduction in the conductance through the transitional layer.

In contrast, simulated flux between the bay and the aquifer in offshore areas of the model domain are sensitive to a reduction in the transitional layer conductance. This is a potentially important limitation for estimating groundwater flux into the bay and saltwater intrusion into the aquifer. Model simulation indicated that fresh groundwater flux has only limited and local influence on bay salinity, which is the primary objective of the model. Saltwater intrusion is not a primary objective of the model, rather is used for qualitative calibration, thus uncertainty in saltwater flux into the aquifer is not considered a major limitation.

ET is one of the largest components of the hydrologic budget. The FTLOADDS simulator used for this model incorporates a complex representation of ET, the PenmanMonteith formulation, which is intended to quantify specific 
processes that remove water from the hydrologic system. This formulation requires input values for stomatal resistance, atmospheric resistance, and albedo, which are poorly known. Some measured ET data exist for similar hydrologic environments, and gross model simulated values are comparable to these data. Furthermore, simulated groundwater heads in the northern part of the model area are moderately sensitive to ET, and simulated salinity in the northern part of the bay is highly sensitive to ET, so the uncertainty in how the simulated ET compares with actual ET is an important limitation on reliability of model results.

The groundwater component of the model is represented with variable hydraulic conductivity in the horizontal dimension and a uniform hydraulic conductivity in the vertical direction. This distribution is informed by published data from field tests. Some uncertainty is associated with hydraulic properties estimated from field tests and with interpolation between locations where data were collected, even if the data may indicate relative distribution of flow properties. Additionally, there are known, laterally extensive, discrete flow and semiconfining zones within the Biscayne aquifer that indicate vertical heterogeneity. Simulated groundwater heads and discharge are sensitive to the values and distribution of the hydraulic conductivity. Simulated bay salinity, however, is less sensitive to the hydraulic conductivity and not a major limitation for the objectives of this model.

In addition, the groundwater component of the model assumes saturated flow through a porous medium. Unsaturated flow may occur in some areas, for example along the Atlantic Coastal Ridge (fig. 5), and parts of the system may exhibit conduit flow, particularly where enhanced dissolution of the limestone has produced extensive zones of high porosity and permeability. These assumptions may have resulted in a different flow field and thus a different calibration compared with a model in which unsaturated flow and conduit flow are incorporated. These features have not been explicitly identified and mapped throughout the simulated area, however, thus making it difficult to incorporate these features in the conceptual model of the system. Although the hydraulic conductivity is represented as spatially variable in the horizontal direction, the hydraulic conductivity is represented as vertically uniform.

A more important limitation to the groundwater component of the model may be the scale of the spatial discretization of the system. The results show a spatial bias in the simulated groundwater heads, with more error indicated generally at observation sites in the northern part of the model and particularly in areas where observation sites are located within the same model cells as major well fields. The discretization may not be refined enough to resolve the flow field around major well fields or represent the spatial variability in hydraulic properties.

Another limitation to the groundwater model involves the calculation of the inland extent of the saltwater interface. The data used to delineate the estimated 1995 saltwater interface are point source data scattered throughout the county and, therefore, do not specify the geometry of the wedge-shaped interface, which is needed to directly compare the simulated results against. Additional discrepancies between the simulated location of the interface and 1995 estimated location may come from the location of model boundaries, variations in the tidal boundary, or errors in aquifer properties, canal conductance, or leakage coefficients. As the saltwater interface extends further inland, these limitations would not influence the area of interest under the bay.

Boundary conditions for the groundwater component of the model at the model extent may contribute notable uncertainty. Ideally, a model would be designed such that these vertical boundaries coincide with and represent actual hydrologic boundaries. For this model, however, the actual hydrologic boundaries would be so far from the area of interest as to add unnecessary computations to the simulations. Instead, these boundaries are intended to be distant enough from the area of interest that their influence on model results is limited. So, although there is vast uncertainty regarding the groundwater flows from the Everglades toward the urbanized eastern part of the model area, simulated groundwater heads and groundwater discharge to the bay are minimally sensitive to the nature of the boundary condition along the onshore vertical boundary of the groundwater system.

Despite the numerous limitations discussed, the model represents a valid approach and useful tool to simulate the complex hydrologic system in South Florida. In South Florida, the groundwater and surface-water systems are inextricably linked in several ways, and the model documented in this report provides an approach that allows explicit representation of both systems. A variety of data types are used to calibrate the model, which constrains model uncertainty. Even though all physical properties used in the model are not measured and many of those that are measured contribute uncertainty to the model, the model is designed to simulate more complex processes rather than empirical relations. Although the model simulates processes on a daily or shorter time scale, the primary objective of this model is to simulate changes in bay salinity on a monthly basis. As a corollary, although the model provides reasonable results for long-term simulations and predictions, it is not intended, and should be used with caution, for interpreting shorter-term events.

\section{Summary}

Biscayne Bay has experienced episodic hypersaline events in recent years (salinity greater than 35 practical salinity units). Prolonged hypersalinity in Biscayne Bay can potentially cause permanent damage to, or loss of, brackish nursery habitats and mangrove forests located in the transition zone between the terrestrial and marine environments. Factors that may contribute to hypersaline conditions and prolonged hypersalinity events include reduced discharge of fresh canal water into the bay, lower than normal precipitation, increased evapotranspiration (ET), reduced discharge 
of fresh groundwater into the bay, or increased discharge of salty groundwater into the bay. The U.S. Geological Survey (USGS), in cooperation with the South Florida Water Management District (SFWMD), investigated the effects of changes in temporal and spatial precipitation patterns and freshwater canal discharge to identify the factors controlling hypersalinity events and evaluate the possible effects of changes in canal management on Biscayne Bay salinity. Information obtained from this study may be used to provide information to manage and balance competing demands on the water resources in Southeast Florida.

The purpose of this report is to (1) evaluate the factors that contribute to hypersalinity events, particularly during April to August 2004, and (2) test the effects of possible changes in precipitation patterns and canal flows into Biscayne Bay on bay salinity. To meet these objectives, the USGS constructed a coupled surface-water/groundwater numerical flow model that accounts for freshwater flows into Biscayne Bay through the canal system, leakage of salty bay water into the underlying Biscayne aquifer, discharge of fresh and salty groundwater from the Biscayne aquifer into the bay, direct effects of precipitation on bay salinity, indirect effects of precipitation on recharge to the Biscayne aquifer, direct effects of ET on bay salinity, indirect effects of ET on recharge to the Biscayne aquifer, and maintenance of mass balance of both water and solute. The model is based on a previously developed groundwater flow and solute-transport model used to estimate groundwater flux into Biscayne Bay, but the model specifically simulates salinity distribution in the bay and accounts for additional processes that likely contribute to Biscayne Bay salinity.

The model was developed using a modified version of the Flow and Transport in a Linked Overland/Aquifer Density Dependent System (FTLOADDS) simulator, which accounts for mass balanced flow and solute transport within and between the surface-water and groundwater systems, exchange between surface water and groundwater in multiple aquifer layers, and solar radiation as a function of albedo in the calculation of ET flux. The model domain encompasses an approximately 4,000 square kilometer $\left(\mathrm{km}^{2}\right)$, highly developed urban area with sections of agriculture use, wetlands, and the Biscayne National Park (BNP). The model extends from the Broward County/Miami-Dade County line south into Barnes Sound, and from the eastern boundary of the Everglades National Park eastward to the BNP/Atlantic Ocean boundary, including all of Biscayne Bay. The grid consists of 93 columns and 173 rows of uniformly sized cells (500 meters (m) on a side). The groundwater component of the model is composed of 20 layers within the Biscayne aquifer. The model simulates groundwater flow, groundwater/surface-water exchange through the canals and bay floor, salinity transport in both surface and groundwater flow systems, and heat transport in the surface-water system. Using a formulation that incorporates the Manning's $n$ frictional factor, the surface-water component simulates overland flow in both wetland and urban areas, although most of the flow in urban areas moves vertically downward to recharge the underlying aquifer.
The model was calibrated to observed groundwater heads, estimated base flow (groundwater/surface-water exchange through the primary canals), and measured bay salinity and temperatures from 1996 to 2004, as well as the location of the freshwater-saltwater interface in the aquifer. Properties adjusted by the trial-and-error method to fit the model included ET rate limiters, canal vertical hydraulic conductance, leakage rate coefficients (transition-layer thickness and hydraulic conductivity), Manning's $n$ value, and delineation of rainfall zones. Stressors for the groundwater component of the model included groundwater pumpage, recharge, and ET, and stressors for the surface-water component of the model included ET from both onshore and bay water surfaces.

For the 154,500 daily groundwater-level observations at the 47 monitoring sites, the model produces an overall mean error (ME) of $0.12 \mathrm{~m}$, mean absolute error (MAE) of $0.22 \mathrm{~m}$, and root mean square error (RMSE) of 0.33 $\mathrm{m}$. The positive value for ME indicates that the model is simulating heads that are, on average, higher than observed values. The MAE is 3 percent of the overall range of observed values (lowest measured head, in meters, minus highest measured head, in meters) and 11 percent of the average range of values at each of the 47 sites. The RMSE indicates that the majority of the simulated values are within plus or minus 0.33 $m$ of the ME.

The ME is near zero during most of the dry season, indicating a seasonal bias in model error. The seasonal bias in error may be the result of less water being routed into surface runoff or lost to ET in the model than in the actual system, resulting in an excess of water recharging the Biscayne aquifer and correspondingly higher simulated water levels. A spatial bias in ME values also was calculated for each of the 47 observation sites with mostly positive values in the northern coastal and southern regions of the model and a cluster of negative values in the northern inland part of the model area.

In general, simulated base-flow patterns and directions resemble those of estimated canal base flows. Discrepancies between simulated and estimated base flows may be the result of overestimated simulated aquifer recharge relative to surface-water runoff, not accounting for secondary and smaller canals in the model, and the inability of the model to simulate specific canal features as in the $\mathrm{C}-111$ canal.

The simulated distribution of saltwater at the base of the Biscayne aquifer generally shows a more landward extent than the 1995 estimated saltwater-freshwater interface in the northern part of the study area and a more seaward extent in the southern part of the study area. Simulated bay salinity values show similar spatial distribution and seasonal patterns as those derived from measured values, and the MAE is 2.4, though the range of simulated values is generally smaller than that of the measured data, particularly for sites with larger ranges. Simulated bay temperatures also show patterns similar to those derived from measured data, though simulated values tend to underestimate measured values by an average of 1.7 degrees Celsius. 
Flow budget calculations indicate that tidal flux accounts for about 99 percent of the water budget, with precipitation and surface-water flow at the coastal control structures making up most of the remaining 1 percent. Groundwater flux is a minor component of the overall flow budget but may be a more important factor in bay salinity in some areas, for example in the southern parts of the bay where the canal system is not as extensively developed or controlled as in the central and northern parts of the bay. Combined, precipitation and ET (largely ET over the bay) are the largest components of the hydrologic budget over the entire system, with exception of the tidal flux. The balance of precipitation and ET during the wet season generally results in a reduction of bay salinity, whereas the balance of precipitation and ET during the dry season generally results in an increase in bay salinity. During years when wet season precipitation is lower than average, for example less than 70 percent total precipitation for an average year, ET could outweigh precipitation over the bay for essentially the entire year.

Hypersalinity is more prone to occur near the end of the dry season because precipitation rates are generally lower, canal discharge rates (which are strongly correlated to precipitation rates) are also generally lower, and ET rates are higher than during the rest of the year. The hypersalinity event of 2004 followed several years of relatively low precipitation and correspondingly reduced canal-structure releases. Furthermore, the dry season in 2004 was unusually extensive, continuing into July, and losses to ET exceeded freshwater input to the bay. Thus, hypersalinity is ultimately the result of a cumulative deficit of precipitation.

In general, simulated groundwater levels are most sensitive to decreasing river conductance, particularly in the southern part of the model area, and to elimination of the leakage between the surface-water and groundwater systems, particularly in the northern part of the model area. Generally, simulated groundwater levels are insensitive to modifications of the general head boundary condition and to reduction in leakage rate. The simulated total groundwater discharge into the bay is most sensitive to changes in leakage between the surface-water and groundwater systems, but the estimated freshwater fraction of groundwater discharge to the bay is more sensitive to the value and distribution of hydraulic conductivity than other tested factors. Simulated bay salinity showed discernable sensitivity, primarily in the southern part of the bay, to ET and leakage between the surface-water and groundwater systems.

Scenarios representing changes in canal flux and precipitation were evaluated to test potential effects on Biscayne Bay salinity as a result of future changes in canal management or weather patterns. Simulations show that elimination of canal flux into the Bay resulted in higher bay salinity, doubling the canal fluxes resulted in a reduction of salinity, and setting uniform canal fluxes resulted in a more subdued salinity fluctuation, and that these effects were more pronounced in the northern part of the bay than in the southern part of the bay. Simulation results showed that doubling precipitation resulted in a reduction of bay salinity and reducing precipitation by half resulted in an increase in bay salinity, and that the effects are more pronounced in the southern part of the bay than in the northern part of the bay.

Model results should be interpreted in light of model limitations. The model is designed to address specific questions about the hydrologic system and may be less appropriate for addressing other issues or examining conditions substantially different from those described in this report. The model is limited by the representation of the system and conceptual model, uncertainty in physical properties used to describe the system or processes, and in the spatial distribution of physical properties, the scale and discretization of the system, and the representation of the boundary conditions. These limitations are manifested in the model error. Despite its limitations, the model quantifies the factors and complexities in the hydrologic system that contribute to hypersaline conditions in Biscayne Bay and represents the system within demonstrable fit objectives.

\section{References Cited}

Anderson, M.P., and Woessner, W.W., 1992, Applied groundwater modeling, Simulation of flow and advective transport: San Diego, Calif., Academic Press, Inc., 381 p.

Bachman, P.M., and Rand, G.M., 2008, Effects of salinity on native estuarine fish species in South Florida: Ecotoxicology, v. 17, p. 591-597.

Bellmund, Sarah, Graves, Greg, Renshaw, Amy, Jobert, Herve, and Kearns, Ed, 2008, Biscayne Bay nearshore continuous salinity monitoring, in 2008 Greater Everglades Ecosystem Restoration Planning, Policy and Science Meeting, Program \& Abstracts, July 28-August 1, 2008, Naples, Fla., p. 149 (accessed January 6, 2012, at http://conference.ifas. ufl.edu/GEER2008/pdf/Abstract_BOOK.pdf; presentation accessed January 6, 2012, at http://conference.ifas.ufl.edu/ GEER2008/Presentation_PDFs/Wednesday/Royal\%20 Palm\%20III/1600\%20G\%20Graves.pdf).

Bellmund, Sarah, Renshaw, Amy, Mayoral, Helen, Jobert, Herve, and Tilghman, Chris, 2007, Annual report-Salinity sampling in Biscayne Bay (2005-2006): Biscayne National Park, A report to the U.S. Army Corps of Engineers for the Monitoring and Assessment Plan of the Comprehensive Everglades Restoration Plan for RECOVER Assessment Team Southeast Estuary Subteam (accessed January 6, 2012, at http://www.evergladesplan.org/pm/ssr_2009/ssr_ $p d f_{s} / h c \_s c s \_s a l i n i t y \_b b \_p i$ report_2006.pdf).

Biscayne Bay Partnership Initiative, Policy Development Committee, 2001, A bright, great bay/Biscayne Bay Partnership Initiative, Policy Development Committee: Fort Lauderdale, Fla., FAU/FIU Joint Center for Environmental \& Urban Problems. 
Boyer, J.N., 2004, South Florida coastal water quality monitoring network-FY2004 Cumulative Report to the South Florida Water Management District (Contract No. C-15397): Miami, Fla., Southeast Environmental Research Center, Florida International University, 91 p.

Browder, J.A., Alleman, Richard, Markley, Susan, Ortner, Peter, and Pitts, P.A., 2005, Biscayne Bay conceptual ecological model: Wetlands, v. 25, no. 4, p. 854-869.

Browder, J.A., and Robblee, M.B., 2009, Pink shrimp as an indicator for restoration of Everglades ecosystems: Ecological Indicators, v. 9S, p. S17-S28.

Browder, J.A., Zein-Eldin, Z., Criales, M.C., Robblee, M.B., and Jackson, T.L., 2002, Dynamics of pink shrimp recruitment in relation to Florida Bay salinity and temperature: Estuaries, v. 25, no. 6B, p. 1335-1371.

Brown, G.L., McAdory, Robert, Nail, G.H., Sarruff, M.S., Berger, R.C., and Granat, M.A., 2003, Development of twodimensional numerical model of hydrodynamics and salinity for Biscayne Bay, Florida: U.S. Army corps of Engineers, Engineer Research and Development Center, Coastal and Hydraulics Laboratory, ERDC/CHL TR-03-10.

Brutsaert, Wilfried, 1982, Evaporation into the atmosphere: The Netherlands, Kluwer Academic Publishers, 299 p.

Compaq Computer Corporation, 1999, Compaq Fortran reference manual: Compaq Computer Corporation, Houston, Tex., [variously paged].

Cooper, R.P., and Lane, James, 1987, An atlas of eastern Dade County surface water management basins: South Florida Water Management District Technical Memorandum, 97 p.

Eagleson, P.S., 1970, Dynamic hydrology: New York, McGraw-Hill, 462 p.

Fish, J.E., 1988, Hydrogeology, aquifer characteristics, and ground-water flow of the surficial aquifer system, Broward County, Florida: U.S. Geological Survey Water-Resources Investigations Report 87-4034, 92 p.

Fish, J.E., and Stewart, M.T., 1991, Hydrogeology of the surficial aquifer system, Dade County, Florida: U.S. Geological Survey Water-Resources Investigations Report 90-4108, 56 p.

Fitterman, D.V., Deszcz-Pan, M., and Stoddard, C.E., 1999, Results of time-domain electromagnetic soundings in Everglades National Park, Florida. U.S. Geological Survey Open-File Report 99-426, 152 p.

German, E.R., 2000, Regional evaluation of evapotranspiration in the Everglades: U.S. Geological Survey WaterResources Investigations Report 00-4217, 48 p.
Guo, Weixing, and Langevin, C.D., 2002, User's guide to SEAWAT - A computer program for simulation of threedimensional variable-density ground-water flow: U.S. Geological Survey Techniques of Water-Resources Investigations, book 6, chap. A7, 77 p.

Harbaugh, A.W., Banta, E.R., Hill, M.C., and McDonald, M.G., 2000, MODFLOW-2000, the U.S. Geological Survey modular ground-water model-User guide to modularization concepts and the Ground-Water Flow Process: U.S. Geological Survey Open-File Report 00-92, 121 p.

Ishman, S.E., Cronin, T.M., Brewster-Wingard, G.L., Willard, D.A., and Verardo, D.J., 1998, A record of ecosystem change, Manatee Bay, Barnes Sound, Florida: Proceedings of the International Coastal Symposium (ICS98), Journal of Coastal Research, Special Issue 26, p. 125-138.

Kohout, F.A., 1960a, Cyclic flow of salt water in the Biscayne aquifer of Southeastern Florida: Journal of Geophysical Research, v. 65, no. 7, p. 2133-2141.

Kohout, F.A., 1960b, Flow pattern of fresh water and salt water in the Biscayne aquifer of the Miami area, Florida: International Association of Scientific Hydrology, Commission of Subterranean Waters, p. 440-448.

Kohout, F.A., 1961a, Fluctuations of ground-water levels caused by dispersion of salts: Journal of Geophysical Research, v. 66, no. 8, p. 2429-2434.

Kohout, F.A., 1961b, Case history of salt water encroachment caused by a storm sewer in Miami: Journal of the American Water Works Association, v. 53, no. 11, p. 1406-1416.

Kohout, F.A., 1964, The flow of fresh water and salt water in the Biscayne aquifer of the Miami area, Florida, in Cooper, H.H., Kohout, F.A., and Henry, H.R., eds., Sea water in coastal aquifers: U.S. Geological Survey Water-Supply Paper 1613-C, p. 12-32.

Kohout, F.A., and Hoy, N.D., 1963, Some aspects of sampling salty ground water in coastal aquifers: Ground Water, v. 1, no. 1, p. $28-32$.

Kohout, F.A., and Klein, Howard, 1967, Effect of pulse recharge on the zone of diffusion in the Biscayne aquifer: International Association of Scientific Hydrology, Publication no. 70, p. 252-270.

Kohout, F.A., and Kolipinski, M.C., 1967, Biological zonation related to groundwater discharge along the shore of Biscayne Bay, Miami, Florida: Estuaries, no. 83, p. 488-499.

Langevin, C.D., 2001, Simulation of ground-water discharge to Biscayne Bay, Southeastern Florida: U.S. Geological Survey Water-Resources Investigations Report 00-4251, 127 p. 
Langevin, C.D., Swain, E.D., and Wolfert, M.A., 2005, Simulation of integrated surface-water/ground-water flow and salinity for a coastal wetland and adjacent estuary: Journal of Hydrology, v. 314, p. 212-234.

Leendertse, J.J., 1987, Aspects of SIMSYS2D, a system for two-dimensional flow computation: Santa Monica, Calif., Rand Corporation, $80 \mathrm{p}$.

Lin, H.C., Talbot, C.A., Richards, D.R., Edris, E.V., Jones, N.L., Yeh, G.T., and Cheng, H.P., 2000, Development of a multidimensional modeling system for simulating canal, overland, and groundwater flow in South Florida: Waterways Experiment Station, Vicksburg, Miss., U.S. Army Corps of Engineers report.

Lirman, Diego, and Cropper, W.P., Jr., 2003, The influence of salinity on seagrass growth, survivorship, and distribution within Biscayne Bay, Florida-Field, experimental, and modeling studies: Estuaries, v. 26, no. 1, p. 131-141.

Lirman, D., Deangelo, G., Serafy, J., Hazra, A., Smith Hazra, D., Herlan, J., Luo, J., Bellmund, S., Wang, J., and Clausing, R., 2008, Seasonal changes in the abundance and distribution of submerged aquatic vegetation in a highly managed coastal lagoon: Hydrobiologia, v. 596, issue 1, p. 105-120.

Lorenz, J.J., 1997, The effects of hydrology on resident fishes of the Everglades mangrove zone: National Audubon Society, final report to the South Florida Natural Resources Center, Everglades National Park, 193 p.

Luo, J., and Serafy, J.E., 2003, Time series analysis and statistical modeling of salinity and canal discharges in Biscayne National Park: Miami, Fla., University of Miami, NPSCESU Agreement H5000000494/0006.

MacVicar, T.K., VanLent, Thomas, and Castro, Alvin, 1984, South Florida Water Management Model documentation report: South Florida Water Management District Technical Publication 84-3, 123 p.

Madden, C.J., Rudnick, D.T., McDonald, A.A., Cunniff, K.M., and Fourqurean, J.W., 2009, Ecological indicators for assessing and communicating seagrass status and trends in Florida Bay: Ecological Indicators, v. 9, issue 6, supplement 1, p. S68-S82.

Mazzotti, F.J., and Dunson, W.A., 1984, Adaptations of Crocodylus acutus and alligator for life in saline water: Comparative Biochemistry and Physiology, v. 79, p. 641-646.

McDonald, M.G., and Harbaugh, A.W., 1988, A modular three-dimensional finite-difference ground-water flow model: U.S. Geological Survey Techniques of WaterResources Investigations, book 6, chap. A1, 586 p.

Merritt, M.L., 1996, Numerical simulation of a plume of brackish water in the Biscayne aquifer originating from a flowing artesian well, Dade County, Florida: U.S. Geological Survey Water-Supply Paper 2464, 74 p.
Merritt, M.L., 1997, Simulation of the water-table altitude in the Biscayne aquifer, southern Dade County, Florida, water years 1945-89: U.S. Geological Survey Water-Supply Paper $2458,148 \mathrm{p}$.

Munroe, R.M., and Gilpin, Vincent, 1985, The commodore's story: Miami, Fla., Historical Association of southern Florida, $382 \mathrm{p}$.

National Oceanic and Atmospheric Administration, Tides \& Currents database, accessed April 22, 2005, at http://tidesandcurrents.noaa.gov/.

Parker, G.G., 1945, Salt water encroachment in southern Florida: Journal of the American Water Works Association, v. 37 , no. 6 , p. $526-542$.

Parker, G.G., 1951, Geologic and hydrologic factors in the perennial yield of the Biscayne aquifer, Miami area, Florida: Journal American Water Works Association, v. 43, no. 10, p. $817-835$.

Parker, G.G., Ferguson, G.E., Love, S.K., and others, 1955, Water resources of Southeastern Florida: Geological Survey Water-Supply Paper 1255, 965 p.

Reese, R.S., and Cunningham, K.J., 2000, Hydrogeology of the gray limestone aquifer in Southern Florida: U.S. Geological Survey Water-Resources Investigations Report 99-4213, 244 p.

Ross, M.S., Meeder, J.F., Sah, J.P., Ruiz, P.L., and Telesnicki, G.J., 2000, The southeast saline Everglades revisited-50 years of coastal vegetation change: Journal of Vegetation Science, v. 11, p. 101-112.

de Saint-Venant, B., 1843, Memoir sur un mode d'interpolation applicable a des impossible des equations aux derives partielles, Comptes Rendus, v. XVII.

Schaffranek, R.W., 2004, Simulation of surface-water integrated flow and transport in two dimensions-SWIFT2D user's manual: U.S. Geological Survey Techniques and Methods, book 6, chap B-1, 115 p.

Serafy, J.E., Lindeman, K.C., Hopkins, T.E., and Ault, J.S., 1997, Effects of freshwater canal discharge on fish assemblages in a subtropical bay-Field and laboratory observations: Marine Ecology Progress Series, v. 160, p. 161-172.

Serrano, X., Grosell, M., and Serafy, J.E., 2010, Salinity selection and preference of the grey snapper Lutjanus griseusField and laboratory observations: Journal of Fish Biology, v. 76 , p. $1592-1608$.

Sonenshein, R.S., 1997, Delineation and extent of saltwater intrusion in the Biscayne aquifer, Eastern Dade County, Florida, 1995: U.S. Geological Survey Water-Resources Investigations Report 96-4285, 1 sheet. 
South Florida Water Management District, 1995, Land cover land use 1995: South Florida Water Management District, West Palm Beach, Fla. (accessed December 2, 2011, at $h t t p: / / m y . s f w m d . g o v / g i s a p p s / s f w m d x w e b d c / d a t a v i e w$. asp?query=unq_id=297).

South Florida Water Management District, DBHYDRO database, accessed May 9, 2006, at http://www.sfwmd.gov/ portal/page/portal/xweb\%20environmental\%20monitoring/ dbhydro\%20application.

Swain, E.D., 2005, A model for simulation of surface-water integrated flow and transport in two dimensions-User's guide for application to coastal wetlands: U.S. Geological Survey Open-File Report 2005-1033, 88 p.

Swain, E.D., and Decker, J.D., 2009, Development, testing, and application of a coupled hydrodynamic surface-water/ groundwater model (FTLOADDS) with heat and salinity transport in the Ten Thousand Islands/Picayune Strand restoration project area, Florida: U.S. Geological Survey Scientific Investigations Report 2009-5146, 42 p.

Swain, E.D., Howie, Barbara, and Dixon, Joann, 1996, Description and field analysis of a coupled ground-water/ surface-water flow model (MODFLOW/BRANCH) with modifications for structures and wetlands in southern Dade County, Florida: U.S. Geological Survey Water-Resources Investigations Report 96-4118, 67 p.

Swain, E.D., Wolfert, M.A., Bales, J.D., and Goodwin, C.R., 2004, Two-dimensional hydrodynamic simulation of surface-water flow and transport to Florida Bay through the Southern Inland and Coastal Systems (SICS): U.S. Geological Survey WaterResources Investigations Report 03-4287, 56 p. +6 plates.

Swain, Michael, Swain, Matthew, Lohmann, M.A., and Swain, E.D., 2010, Experimental determination of soil heat storage depth for the simulation of heat transport in a coastal wetland [abst.]: Greater Everglades Ecosystem Restoration (GEER) 2010 Conference, July 12-16, 2010, Naples, Fla.

Thorhaug, A., Roessler, M.A., and Tabb, D.C., 1976, Man's impact on the biology of Biscayne Bay, in Thorhaug, A., ed., Biscayne Bay —Past, present, future: University of Miami Sea Grant Special Report No. 5, p. 301-312.

U.S. Army Corps of Engineers, 2010, Biscayne Bay coastal wetlands draft integrated project implementation report and environmental impact statement (accessed December 2, 2011, at http://www.evergladesplan.org/pm/projects/ docs_28_biscayne_bay_pir.aspx).

Wang, J.D., Luo, J., and Ault, J.S., 2003, Flows, salinity, and some implications for larval transport in south Biscayne Bay, Florida: Bulletin of Marine Science, v. 72, no. 3, p. 695-723.
Wang, J.D., Swain, E.D., Wolfert, M.A., Langevin, C.D., James, D.E., and Telis, P.A., 2007, Applications of FTLOADDS to simulate flow, salinity, and surface-water stage in the southern Everglades, Florida: U.S. Geological Survey Scientific Investigations Report 2007-5010, 112 p.

Wingard, G.L., Cronin, T.M., Dwyer, G.S., Ishman, S.E., Willard, D.A., Holmes, C.W., Bernhardt, C.E., Williams, C.P., Marot, M.E., Murray, J.B., Stamm, R.G., Murray, J.H., and Budet, C., 2003, Ecosystem history of southern and central Biscayne Bay-Summary report on sediment core analyses: U.S. Geological Survey Open-File Report 03-375, 110 p. (accessed January 10, 2012, at http://sofia.usgs.gov/ publications/ofr/03-375/).

Wingard, G.L., Cronin, T.M., Holmes, C.W., Willard, D.A., Dwyer, Gary, Ishman, S.E., Orem, William, Williams, C.P., Albietz, Jessica, Bernhardt, C.E., Budet, C.A., Landacre, Bryan, Lerch, Terry, Marot, Marci, and Ortiz, R.E., 2004, Ecosystem history of southern and central Biscayne Bay-Summary report on sediment core analyses-Year two: U.S. Geological Survey Open-File Report 2004-1312, 117 p. (accessed January 10, 2012, at http://sofia.usgs.gov/ publications/ofr/2004-1312/).

Wolfert, M.A., Langevin, C.D., and Swain, E.D., 2004, Assigning boundary conditions to the Southern Inland and Coastal Systems (SICS) model using results from the South Florida Water Management Model (SFWMM): U.S. Geological Survey Open-File Report 2004-1195, 30 p.

Wolfert, M.A., Langevin, C.D., and Wang, J.D., 2007, Analysis of hypersalinity events in Southwestern Biscayne Bay, Florida: Second National Conference on Ecosystem Restoration, April 23-27, 2007, Kansas City, Mo.

Zheng, Chunmiao, 1990, MT3D-A modular threedimensional transport model for simulation of advection, dispersion, and chemical reactions of contaminants in groundwater systems: Report to the Kerr Environmental Research Laboratory, U.S. Environmental Protection Agency, Ada, Okla., 170 p. 

Appendixes 1-4 


\section{Appendix 1. FTLOADDS Version 3.3 Model Code Modifications from Previous Version}

\section{Leakage Formulation}

In FTLOADDS, leakage between the surface water and groundwater is represented as a function of the groundwater/ surface-water head difference, while conserving water and constituent mass. As a simplification for the South Florida limestone soil conditions, partially saturated soil conditions are not simulated. In the original FTLOADDS leakage scheme (Langevin and others, 2005), leakage is computed as the surface-water/groundwater head difference multiplied by a hydraulic conductivity value divided by a thickness

$$
Q_{\text {leak }}=\frac{K}{b} \Delta h
$$

where

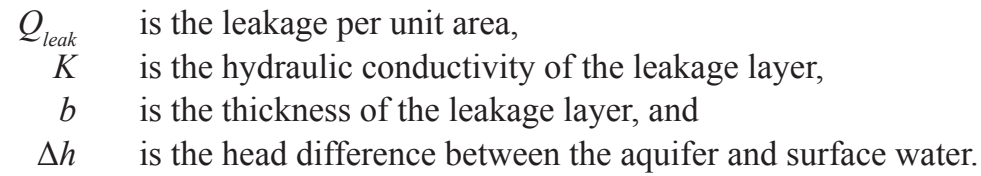

This scheme has been modified to account for a "transition layer" of different (usually smaller) conductivity at the top of the soil when fully saturated, so the composite hydraulic conductivity is the harmonic mean:

$$
Q_{\text {leak }}=\frac{1}{\frac{b_{t l}}{K_{t l}}+\frac{\left(b_{a q}-b_{t l}\right)}{K_{a q}}} \Delta h
$$

where
$K_{t l} \quad$ is the hydraulic conductivity of the transition layer,
$K_{a q} \quad$ is the hydraulic conductivity of the aquifer,
$b_{t l} \quad$ is the thickness of the transition layer, and
$b_{a q} \quad$ is the distance from land surface to the center of the aquifer layer.

This configuration is designed to represent situations typical of the Everglades where a peat layer with a thickness of about 1 meter $(\mathrm{m})$ overlays the limestone.

If the top layer of the aquifer is partially unsaturated, atmospheric pressure is assumed at the bottom of the transition layer, yielding

$$
Q_{\text {leak }}=\frac{K_{t l}}{b_{t l}} \Delta h_{t l}
$$

where $\Delta h_{t l}$ is the difference between the surface-water elevation and the elevation at the bottom of the transition layer.

The formulation assumes the transition layer to always be saturated when surface water is present. This assumption is violated infrequently; when surface water (thus leakage) is absent, the status of the transition layer is irrelevant, and when surface water is introduced, the transition layer quickly becomes saturated.

\section{Surface-Water Leakage with Multiple Groundwater Layers}

In the Biscayne Bay area, land-surface elevations from the inland urban area to the offshore bay bottom are so varied that different hydrologic units of the aquifer are in contact with surface water at various locations. In order to account for these variations when computing groundwater/surface-water leakage, FTLOADDS was modified to allow the leakage to take place in different layers of the aquifer. The recharge package in SEAWAT already had the option for surficial recharge to be assigned to different aquifer layers, which was conveniently modified to represent the layers assigned to surface-water/groundwater leakage. 
This feature uses an array (IRECH) that specifies the land-surface layer number for each row-column location on the grid. The IRECH array is already part of the standard input for the SEAWAT recharge package.

Because of the variable elevation of the Biscayne Bay floor, where the bay intersects with the aquifer layers defined in SEAWAT some of the grid cells are less than 10 centimeters thick. Simulation results showed that these very thin cells can undergo numerical oscillations in head computations, creating instabilities. To simplify numerical algorithms, these thin cells are inactivated in the Biscayne model, and leakage is calculated to the cell beneath.

\section{Maintaining Numerical Stability of Leakage Formulation}

The stability of the leakage is influenced by the different time scales of the surface-water and groundwater flow solutions. In SWIFT2D the solution of the 2-D Saint-Venant equations (de Saint-Venant, 1843) require a relatively short time step; with a time step $\Delta \mathrm{t}$ corresponding to a grid maximum Courant number on the order of 10 :

$$
\frac{\sqrt{g d} \Delta t}{\Delta x} \leq 10
$$

where $g$ is gravitational acceleration, $d$ is the flow depth, and $\Delta x$ is the grid spacing. The Courant criterion is a general requirement for explicit numerical integration in order to accurately represent the surface waves and to avoid instability. The surfacewater module SWIFT2D code employs the Alternating Direction Implicit method, which is locally unconditionally stable for the linearized problem. The temporal variations in boundary conditions and nonlinearity in the relations between variables, however, can cause instabilities in the solution and therefore limits $\Delta t$. Numerical accuracy also limits $\Delta t$.

The solution of the heads and flows in the groundwater module SEAWAT employs a stress period during which the boundary conditions are assumed to be constant. Due to the much slower dynamics of the groundwater flows, a groundwater stress period of 1 day is often adequate and substantially reduces the amount of data used to specify model boundary conditions. When coupling the two models, the disparity between the duration of the surface-water and groundwater time steps must be accounted for. In FTLOADDS the surface-water module SWIFT2D solves for the number of surface-water time steps equal in duration to the corresponding groundwater stress period. For the surface-water solution, the groundwater heads are maintained at their values calculated at the end of the previous stress period. When SWIFT2D finishes surface-water computations for the interval corresponding to the stress period, the calculated leakage and constituent fluxes are summed and applied as constant values to the SEAWAT stress period computation so that the ending time matches the latest SWIFT2D simulation time (Langevin and others, 2005).

As a result of the alternating/sequential surface-water and groundwater flow solutions, numerical instabilities arise when the soil becomes saturated and the aquifer becomes confined. Because of the low primary storage coefficient value resulting from the low compressibility of the water and soil matrix, small fluctuations in the leakage can cause large fluctuations in the groundwater head. For a given stress period, a large downward leakage can cause the groundwater head to go from a value less than the surface-water stage to a value greater than the surface-water stage. This fluctuation induces upward leakage in the stress period that follows, which can be large enough to raise the surface-water stage above the groundwater head again. This tendency to oscillate is a direct consequence of the sequential surface-water and groundwater flow solutions. In real systems, heads and leakages are continuously adjusting. In the model, however, the transition from unsaturated to saturated, confined aquifer conditions as a result of downward leakage can cause instabilities because of the orders-of-magnitude difference in primary and secondary storage (specific yield) coefficients.

One way to address these instabilities is to limit the magnitude of leakage during a stress period, especially when the aquifer is saturated and confined. Simulations were run varying the soil layer and aquifer conductivities to find values that were as large as possible but kept oscillation to a minimum. Results showed that, above a certain threshold, the magnitude of the vertical conductivities did not substantially increase downward leakage under saturated conditions but simply made the head adjustment occur more rapidly. The threshold value above which leakage did not appreciably increase corresponds to a value which would keep the aquifer saturated.

The vertical conductivity threshold depends on multiple site-specific factors, such as horizontal conductivity, aquifer thickness, and surface-water dynamics, but the same effect can be accomplished with leakage limiters to control groundwater head oscillations. Leakage limiters (converted to equivalent depths of water by dividing by cell area) were devised for each of the following cases.

For an unsaturated aquifer (only downward leakage possible) with leakage only into layer 1, the limiter does not allow flux volumes to exceed that of the unsaturated zone times an empirical multiplier $q_{\text {fact }}$ : 


$$
Q_{\lim }=-\left(Z_{\text {land }}-h_{1}\right) S_{y} q_{\text {fact }}
$$

where

$Q_{\lim } \quad$ is the limiting value on the leakage,

$Z_{\text {land }} \quad$ is the land-surface elevation,

$h_{1} \quad$ is the head in the upper aquifer layer, and

$S_{y} \quad$ is the specific yield.

A value of $q_{\text {fact }}$ equal to 1.6 is found to work well in South Florida applications.

For a saturated aquifer and also for surface-water leakage into layers below layer 1 in an unsaturated aquifer, the limiter does not allow leakage to exceed $q_{\text {fact }}$ times the volume which would reverse the head gradient:

$$
Q_{\text {lim }}=-\left(h_{\text {surf }}-h_{1}\right) S_{o} q_{\text {fact }}
$$

where $h_{\text {surf }}$ is the surface-water stage, and $S_{o}$ is the confined storage coefficient.

In addition, a limiter is imposed for downward leakage such that the flux cannot be greater than a multiplier (DEPTHFRACT) times the amount of available surface water:

$$
Q_{\lim }=-\left(h_{\text {surf }}-Z_{\text {land }}\right) \text { DEPTHFRACT }
$$

DEPTHFRACT is nominally set to a value less than 1 ; values below 0.95 have been effective.

For each stress period, leakage summed on a cell-by-cell basis during calculations using SWIFT2D is input into an array called VLEAK, which uses the row numbering of SEAWAT. The leakage values are defined as positive for downward flow. In the interfacing routine SFT1.FOR, the SEAWAT array used for recharge, RECH is assigned the values of VLEAK for transfer of the SWIFT2D computed leakage to SEAWAT. Surficial rainfall recharge is incorporated into the leakage value in SWIFT2D, so the RECH array only needs to pass leakage to SEAWAT. Solute flux is handled in a similar fashion. The array FSAL stores the cumulative solute mass transfer in SWIFT2D during one stress period. From VLEAK and FSAL a flow-weighted average concentration of constituent mass transfer is calculated in routine SWIFT2D.F and assigned to the array of recharge/leakage concentrations $(\mathrm{CRCH})$ in routine SFT1.FOR.

With the leakage limiters described above, maximum leakage can be implemented by setting conductivities in the upper aquifer layer and transition layer sufficiently large enough to allow the limiters to control leakage. The formulations of the leakage limiters do not take into account horizontal flow in the aquifer and surface water, which replaces water moved through vertical leakage. Thus, large losses or gains to a cell by way of vertical leakage can be mitigated by gains or losses from horizontal flow. In some cases, the limiters may be overly restrictive and more leakage is possible without creating instabilities. It is therefore advised to use a value of $q_{\text {fact }}$, greater than one, but just low enough to prevent instabilities. In addition to the limiters, increasing the primary storage coefficient also helps reduce the head fluctuations.

The use of leakage limiters alters the effects of the vertical conductivities. The concern that this could create an artificially low leakage rate must be considered. If the limiters are restricting long-term mean leakage rates, the effective vertical hydraulic conductivity is being reduced below the desired user-specified value. But if the limiters only restrict leakage when alternating recharge and discharge between groundwater and surface water at sequential time steps would occur, then this may be considered compensation for the lack of temporal resolution. Input instructions for the leakage parameters are provided in appendix 2.

\section{Defining Surface-Water Sources, Rainfall, and Evapotranspiration}

Surface-water sources and sinks, leakage, rainfall, and evapotranspiration are defined for the FTLOADDS model through the SOURCEWATER.F subroutine. In addition to the specific modifications described below, the updated subroutine is more modular and more streamlined than previous routines for entering these types of input. The user-input format is described in appendix 2.

The SOURCEWATER.F subroutine allows the user to specify source/sink locations and to distribute a source among multiple cells. Previously, source/sink locations and rates were hardcoded (Wang and others, 2007). In addition, SOURCEWATER.F also now allows the user to define the number and location of zones, as well as a time series of surfacewater sources and sinks. 
The definition of rainfall zones in SOURCEWATER.F was also changed so that the user can define the number and location of zones as well as a time series of values instead of the initially hardcoded format. The user-input format is described in appendix 2.

The incorporation of evapotranspiration (ET) fluxes in SOURCEWATER.F was initially designed to allow multiple zones with different user-input ET rate time series in each zone. The algorithm in SOURCEWATER.F apportions the ET between surface water and groundwater based on surface-water depth. If the volume of water lost to ET over a time step is greater than 0.1 times the surface-water volume, then the volume lost is apportioned to the groundwater model to prevent computational difficulties resulting from very small computed surface-water depths. When water is removed from the groundwater part of the system by ET, the rate declines with depth by the equation

$$
\begin{aligned}
& E T_{G}=P E T\left[1-\frac{\left(Z_{\text {land }}-h_{1}\right)^{2}}{1 \cdot \text { meter }^{2}}\right] \text { for } 1 \mathrm{~m}>Z_{\text {land }}-h_{1}>0 \mathrm{~m} \\
& E T_{G}=0 \text { for } Z_{\text {land }}-h_{1}>1 \mathrm{~m}
\end{aligned}
$$

where $E T_{G}$ is the evapotranspiration rate from the groundwater, and $P E T$ is the user-input potential evapotranspiration. In order to make the model more universally applicable, the code was modified to allow user input of separate PET zones. ET is then calculated from PET using equation 1-8. The user-input format is described in appendix 2.

\section{Computing Evapotranspiration from Latent Heat}

When the heat-transport algorithm is used in FTLOADDS v.3.3 (Swain and Decker, 2009), ET flux rates for surface water and groundwater are determined from the latent heat computations instead of the PET zone data. The cell-by-cell latent heat values are divided by the coefficient of latent heat and the water density to obtain the volumes of water lost to ET. This allows the spatial variation in ET flux to be calculated on a cell-by-cell resolution.

An additional modification has been made to the heat-transport algorithms when the Penman Montieth equation is used to compute latent heat (Eagleson, 1970):

$$
Q_{L H}=\frac{\Delta\left(Q_{A S R}-Q_{R}\right)+\left(\rho_{a} c_{p} / r_{a}\right)\left(e_{s}-e_{a}\right)}{\Delta+\gamma\left(1+r_{s} / r_{a}\right)}
$$

where

$Q_{L H} \quad$ is the latent heat,

$Q_{A S R} \quad$ is net solar radiation flux or absorbed short-wave radiation,

$Q_{R} \quad$ is long-wave radiation flux exchanged between the water surface and the surroundings,

$\rho_{a} \quad$ is the density of air,

$c_{p} \quad$ is the constant pressure specific heat of air,

$e_{s} \quad$ is the saturation vapor pressure at the air temperature,

$e_{a} \quad$ is the vapor pressure at the air temperature,

$\Delta \quad$ is the slope of the saturation vapor-pressure curve,

$\gamma \quad$ is the psychometric constant,

$r_{s} \quad$ is the bulk stomatal resistance, and

$r_{a}$ is the aerodynamic resistance term given by:

$$
r_{a}=K_{e} \frac{1}{\kappa^{2} U} \frac{z_{e}-D}{z_{u}-D} \ln ^{2}\left(\frac{z_{u}-D}{z_{o}}\right)
$$

where
$K_{e} \quad$ is the eddy diffusivity ratio,
$\kappa \quad$ is the Von Karmen constant $=0.41$,
$U$ is wind velocity,
$z_{e} \quad$ is the height where vapor pressure is defined, 
$z_{u} \quad$ is the height where wind speed is defined,

$D \quad$ is the boundary-layer thickness, and

$z_{o} \quad$ is the aerodynamic roughness.

As the wind velocity is the only temporally variable quantity in equation 1-10, a dimensionless constant for a given location is:

$$
r_{a} U=K_{e} \frac{1}{\kappa^{2}} \frac{z_{e}-D}{z_{u}-D} \ln ^{2}\left(\frac{z_{u}-D}{z_{o}}\right)
$$

The value of $r_{a} U$ is hardcoded and during computation is divided by the current value of $U$ to supply the $r_{a}$ value for equation 1-9. Bulk stomatal resistance, $r_{s}$ is user-defined; however, both $r_{s}$ and $r_{a} U$ vary spatially, depending on land cover and vegetation. In open water with no emergent vegetation, $r_{s}$ is near zero, and $r_{a} U$ is higher due to the lower values of $z_{o}$ as shown in equation 1-11. So, in the FTLOADDS version 3.3, both the $r_{s}$ and $r_{a} U$ values change at a given water-depth threshold. The userdefined value of $r_{s}$ is used for depths less than the threshold, and $r_{s}$ is set to zero for depths greater than the threshold. Two values of $r_{a} U$ are coded in FTLOADDS, a value of 100 for depths less than the threshold and 350 for depth greater than the threshold.

In the latent heat formulation, a reflection coefficient, albedo, is used to modify the solar radiation to account for heat losses in the system oweing to reflectivity. The current code does not input albedo directly, rather the input solar radiation data are multiplied by the albedo in preprocessing, and the resulting net solar radiation is input to the model. Swain and Decker (2009) derived a wetland albedo of 0.169. However, the initial calibration of the Biscayne model indicated that this amount does not reflect enough energy, and physical experiments representing wetland soil and water (Swain and others, 2010) support a higher value of albedo. An albedo of 0.28 was determined to work well in the Biscayne area.

\section{Incorporation of Hydraulic Barriers}

The subroutine CVAL that calculates Chézy coefficients for the surface-water simulation also computes an effective Chézy coefficient for model-cell faces that represent hydraulic barrier locations in order for the flow to have the correct resistance. The formulation that relates the effective Chézy coefficient to the hydraulic barrier flow coefficients is discussed in Swain and Decker (2009). The inputs for hydraulic barriers are in records 9 through 11 of part 2 in the surface-water module SWIFT2D input dataset (see appendix 2). This representation is a significant simplification over the original SWIFT2D scheme, which required four subroutines to represent flow over hydraulic barriers specified as boundary conditions. As the barrier formulation has been changed, some variable definitions are slightly different than described in Schaffranek (2004) for the original SWIFT2D code and Swain (2005).

\section{Defining Input File Names and Locations}

Input files to run the SWIFT2D surface-water module in FTLOADDS are specified in a master file called SWIFT2D. MTR. The master file includes the control file (.ctl), the main input file (.inp), the simulation printout (.prt), and the run log file (.log). Other output options, some obsolete, are retained in the SWIFT2D.MTR format for backwards compatibility (see below). In version 3.3, the subroutine SIOFILE was modified so that additional input files needed for the revised code can be named by the user in SWIFT2D.MTR. The added files include physical property and flux inputs: frictional resistance, surface-water flows, PET, rainfall, wind, and tidal characteristics. An example SWIFT2D.MTR file is shown below, where the type of input is followed by a path to an input file.

INSTREAM-CONTROL INPUT : ..linputtimeBB.ctl

IDP-CREATED INPUT (SIMINP): .. linputtimebb8.inp

TIME-VARYING WIND INPUT :

SIMULATION PRINTOUT : ... Irun|timeBB.prt

RUN STATISTICS PRINTOUT : ..Irun|timeBB.log

PARTICLE-TRACKING PRINTOUT :

STAGE \& TRANSPORT PRINTOUT : 
MODEL OUTPUT (SIMMOT):

HISTORY OUTPUT (SIMHST): ...run\timeBB.hst

RESTART OUTPUT (SIMRST):

COARSE GRID OUTPUT (CGDATA): ..।run $\backslash$ timeBB.cgd

EMERGENCY RESTART 1 (EMRST1):

EMERGENCY RESTART 2 (EMRST2):

MINIMUM VELOCITY OUTPUT :

FRICTIONAL RESISTANCE INPUT : .. input|VEGMANNING.DAT

SURFACE-WATER INPUT FLOWS : ..linputlinputflows.dat

POTENTIAL EVAPOTRANSPIRATION: ..linput\MODELPET.DAT

RAINFALL INPUT : ..linput INPUTRAIN.DAT

WIND INPUT : ..linputlinputwind.dat

TIDAL BOUNDARY INPUT : ..linputtimebb8.inp

\section{Streamlining of Code}

When SWIFT2D was incorporated into FTLOADDS version 1.1, a number of older preprocessing and graphic output options were discontinued, including the IDP input data processor (Schaffranek, 2004). Consistent with the modular structure of SEAWAT, in FTLOADDS version 3.3, outdated and unused code was removed. Primary changes include the removal of subroutines for:

obsolete representation of flow sources (subroutine ADJSRC),

obsolete representation of hydraulic barriers (subroutines BARENU, BARENV, SLUCEU, and SLUCEV),

unused DIGS-GKS output graphics (subroutine DIGSGKS, GRQLC),

the obsolete SWIFT.IDP preprocessor (subroutines GET012, GET_01, GET_CR, GETCHR, GETCHV, GETCRT, GETCVL, GETFLT, GETIFL, GETINT, GETIVL, GETNUM, GETOPT, GETRNM, GETRVL, GETSTR),

unused simulation history output (subroutine HISTRY),

unused plotting routine (subroutine PLTDAT),

unused printout options (subroutine PRHOUT), and

unused smoothing routine (subroutines SMOOT, TIMESMO).

\section{Code Modifications to Use Modules}

The versions of the FTLOADDS code up through version 3.2 used common statements predominantly for passing information between subroutines, especially in the SWIFT2D part of the simulator. This creates relatively bulky code, as the common statements and dimensions are repeated in each subroutine. In addition, the common statements need to be repeated in all accessed routines, or some compiled versions of the code will lose variable values.

To reduce redundancy and make the code more concise and modular in FTLOADDS version 3.3, common statements were largely replaced with the FORTRAN Module function. Modules contain specifications and definitions that can be used in one or more program units, and the module is accessed with a USE statement (Compaq Computer Corporation, 1999).

Three modules were developed for FTLOADDS version 3.3, SEAWATDIM, SWIFTDIM, and COUPLING, which contain the variables used in SEAWAT, SWIFT2D, and the FTLOADDS coupling, respectively. SEAWAT stores parameter values in 
several large arrays (referred to as X, Y, Z, and IY) and passes these arrays to the subroutines through the use of pointers. These arrays were not placed in SEAWATDIM because they do not rely on bulky common statements. The SEAWATDIM module is only used in the MODWAT subroutine (the core routine of SEAWAT) to retain storage of all relevant variables and arrays.

The SWIFDIM module is the largest and is used in 57 subroutines. It contains variables and arrays in addition to dimensions for the simulation. Many variables called by subroutine have been eliminated; however, it is necessary to retain these subroutines for cases where a subroutine is called multiple times with different variables passed. Variables continue to be passed to the subroutines:

OPNFIL - Opens a sequential formatted file for program output,

OPNFUR - Opens an unformatted file for program input,

OPNFLU - Opens a sequential unformatted file for program output,

OPNRDR - Opens a formatted file for program input,

SIOFIL - Controls the interactive file designation procedure, that opens all input and output files,

SWMOV0 - Initializes an array to zero,

SWMOVA - Moves the average values from two arrays to another,

SWMOVL - Initializes an array to a value,

SWMOVE - Moves values from one real array to another,

SWMOVI - Moves values from one integer array to another,

SWMOVC - Moves values from one CHARACTER array to another,

UOPFIL - Opens an input/output file associated with unit [IN], status [ISTAT], and file name [FLNAME].

The COUPLING module contains variables and arrays used in the coupling between SEAWAT and SWIFT2D, including dimensions, pointers for arrays, leakage data, and flags. The COUPLING module is used in the following packages:

FTLOADDS main code - Calls SWIFT2D and SEAWAT,

SEAWAT MODWAT package - Calls all SEAWAT routines,

BAS package - Sets up discretization and basic boundary type data for the groundwater flow simulation,

BTN package - Sets up groundwater transport simulation,

GHB package - Defines general head-dependent flux groundwater boundaries and the subroutines:

SWIFT2D main program - Coordinates routines for surface-water flow computations,

LEAKAGE subroutine - Computes groundwater/surface-water leakage and constituent flux,

RDONCE subroutine - Reads input data for SWIFT2D simulation,

SOURCEWATER subroutine - Defines surface-water sources and sinks, leakage, rainfall, and evapotranspiration,

TIDAL subroutine - Defines tidal boundaries for surface water, and

GETWIND subroutine -Reads and processes wind stress input. 


\section{Appendix 2. Parameters for FTLOADDS Input Files}

\section{Input of Leakage Parameters}

The parameters that define leakage are read from the .inp2 file and are free format separated by spaces or commas.

The input variable definitions are as follows:

INPUT FORMAT

Record 1 Data: LOCAT,CNSTNT,FRMTIN

LOCAT is a flag defining whether the transition-layer thickness is a constant

$(\mathrm{LOCAT}=0)$ or is read from an array $(\mathrm{LOCAT}=1)$.

CNSTNT is the transition-layer thickness if a constant value is requested.

FRMTIN is the format that the transition-layer thickness is read in if an array is requested.

Record 2 Data: THICK(NMAX,MMAX)

If an array of transition-layer thickness values is requested, THICK is an array of transition-layer thickness values where NMAX is the number of rows and MMAX is the number of columns.

Note: If the first value of THICK is negative, FTLOADDS runs a surface-water only simulation.

Record 3 Data: LOCAT,CNSTNT,FRMTIN

LOCAT is a flag defining whether the top-layer aquifer hydraulic conductivity is a constant $($ LOCAT $=0)$ or is read from an array (LOCAT $=1)$.

CNSTNT is the top-layer aquifer hydraulic conductivity if a constant value is requested.

FRMTIN is the format that the top-layer aquifer hydraulic conductivity is read in if an array is requested.

If an array of top-layer aquifer hydraulic conductivity values is requested then the following records need to be defined.

Record 4 Data: AQUC(NMAX,MMAX)

AQUC is an array of top-layer aquifer hydraulic conductivity values where NMAX is the number of rows and MMAX is the number of columns.

\section{Record 5 Data: LOCAT,CNSTNT,FRMTIN}

LOCAT is a flag defining whether the transition-layer hydraulic conductivity is a constant $(\mathrm{LOCAT}=0)$ or is read from an array (LOCAT $=1)$.

CNSTNT is the transition-layer hydraulic conductivity if a constant value is requested.

FRMTIN is the format that the transition-layer hydraulic conductivity is read in if an array is requested.

\section{Record 6 Data: ALAYC(NMAX,MMAX)}

If an array of transition-layer hydraulic conductivity values is requested, then ALAYC is entered as an array of transitionlayer hydraulic conductivity values where NMAX is the number of rows and MMAX is the number of columns.

\section{User Input of Surface-Water Inflows and Outflows}

The variables in the input file for surface-water inflows and outflows are free format separated by spaces or commas. Currently all solute concentrations are assumed to be zero except for temperature, which is set to the value of temperature in input variable q4 in the time-series data (Swain, 2005, p. 75). Ranges of cells can be horizontal, vertical, or at a 45-degree angle. No other orientation is supported.

INPUT FORMAT

Record 1 Data: NUMSTRUCS

NUMSTRUCS is the total number of inflow points. 
For each inflow point:

\section{Record 2 Data: NFLWPTS, NRANGES}

NFLWPTS is the number of individual cells among which to divide flow.

NRANGES is the number of ranges of cells among which to divide flow.

For each individual cell within each inflow point:

Record 3 Data: MSTRUC, NSTRUC, IXYFLOW

MSTRUC is the column where the cell is located.

NSTRUC is the row where the cell is located.

IXYFLOW is a flag to indicate if input is in: $1=\mathrm{x}$-direction, $2=\mathrm{y}$-direction, or, $3=$ both.

Note: If only one row of input flows per time is defined, use IXYFLOW $=3$. If two rows of input flows have the same time, the first row is assigned to the $\mathrm{x}$-direction and the second to the $\mathrm{y}$-direction. IXYFLOW $=1$ uses only the $\mathrm{x}$-flows, IXYFLOW $=2$ uses only the $y$-flows, and IXYFLOW $=3$ uses both $\mathrm{x}$ - and $\mathrm{y}$ - flows.

For each range of cells within each inflow point:
Record 4 Data: MSTRUC1, NSTRUC1
Record 5 Data: MSTRUC2, NSTRUC2
MSTRUC1 is the column of the cell that starts the range.
NSTRUC1 is the row of the cell that starts the range.
MSTRUC2 is the column of the cell that ends the range.
NSTRUC2 is the row of the cell that ends the range.

For each time step:

Record 6 Data: STRCFLOW(1), STRCFLOW(2), ... STRCFLOW(NUMSTRUCS+1)

STRCFLOW(1) is the time in days.

STRCFLOW(2) through STRCFLOW(NUMSTRUCS+1) is the flow at inflow points 1 through NUMSTRUCS.

\section{User Input of Rainfall Data}

The variables in the input file for rainfall are free format separated by spaces or commas. Currently all solute concentrations are considered zero in rainfall, and the rainfall temperature is set to the dewpoint temperature (Swain and Decker, 2009). Rainfall input is assigned in rectangular areas as defined by the bounding rows and columns of a rectangular area. Note that rainfall data can be applied to multiple rectangular zones in the model grid. This allows the user to define several rectangular zones to build an irregular shaped area using a single rainfall dataset.

INPUT FORMAT

For each set of rainfall data:

Record 1 Data: IZ

$\mathrm{IZ}$ is the number of the rain dataset ( $\mathrm{IZ}=0$ indicates end of dataset definition).

Record 2 Data: NR

NR is the number of rectangular zones to which the dataset applies. 
For each rectangular zone:

Record 3 Data: MS, ME, NS, NE

MS is the column of the left side of the zone.

$\mathrm{ME}$ is the column of the right side of the zone.

NS is the row of the bottom of the zone.

$\mathrm{NE}$ is the row of the top of the zone.

For each time step:

Record 4 Data: RAIN(1), RAIN(2),.. RAIN(IZ+1)

RAIN(1) is the time in days.

RAIN(2) through RAIN(IZ+1) are rainfall rates for datasets 1 through IZ.

\section{User Input of Evapotranspiration Data}

The variables in the input file for potential evapotranspiration (PET) are free format separated by spaces or commas. PET input is assigned in rectangular areas as defined by the bounding rows and columns of a rectangular area. Note that each PET dataset can apply to multiple rectangular zones in the model grid. This allows the user to define several rectangular zones to build an irregular shaped area using a single PET dataset.

INPUT FORMAT

For each set of PET data:

Record 1 Data: IZ

$\mathrm{IZ}$ is the number of the PET dataset (IZ $=0$ indicates end of dataset definition).

Record 2 Data: NR

NR is the number of rectangular zones to which the dataset applies.

For each rectangular zone:

Record 3 Data: MS, ME, NS, NE

MS is the column of the left side of the zone.

$\mathrm{ME}$ is the column of the right side of the zone.

NS is the row of the bottom of the zone.

$\mathrm{NE}$ is the row of the top of the zone.

For each time step:

Record $4 \quad$ Data: $\quad$ PET(1), PET(2),... PET(IZ+1)

PET(1) is the time in days.

PET(2) through PET(IZ+1) are potential evapotranspiration rates for datasets 1 through IZ. 


\section{User Input of Hydraulic Barrier Data}

For each hydraulic structure:

Record 9 Data: IBUV, I, MBAR, NBAR

Format: $4 \mathrm{I} 5$

IBUV defines the orientation of the barrier flow ( 1 = flow along rows, 2 = flow along columns),

I is the sequence number,

MBAR is the column number of the barrier location, and

NBAR is the row number of the barrier location.

Record 10 Data: IBUV, I, BARMU(1,I), BARMU(2,I), BARMU(3,I)

Format: 2I5, 3E8.0

IBUV defines the orientation of the barrier flow ( 1 = flow along rows, 2 = flow along columns),

I is the sequence number,

$\operatorname{BARMU}(1, \mathrm{I})$ is the barrier flow coefficient corresponding to the weir free-flow (unsubmerged tailwater) coefficient times the barrier width and the square-root of gravitational acceleration,

$\operatorname{BARMU}(2, \mathrm{I})$ is the barrier flow coefficient corresponding to the weir submerged-flow (submerged tailwater) coefficient times the barrier width and the square-root of gravitational acceleration, and

BARMU(3,I) is the effective Chezy resistance factor when there is no flow over the barrier. This allows some flux through the barrier, such as seepage or local underflow.

Note: Three additional values in the BARMU array are currently unused.

Record 11 Data: IBUV, I, SILL, GATE, BRAT

Format: 2I5, 3E10.0

IBUV defines the orientation of the barrier flow ( 1 = flow along rows, 2 = flow along columns),

I is the sequence number,

SILL is elevation of the barrier sill expressed as distance below datum (positive downward),

GATE is the gate height above barrier (currently unused), and

BRAT is the ratio of the barrier width to the model cell width (currently unused). 


\section{Appendix 3. Groundwater Boundaries for Layers 1-20 Used in the Biscayne Bay Model}

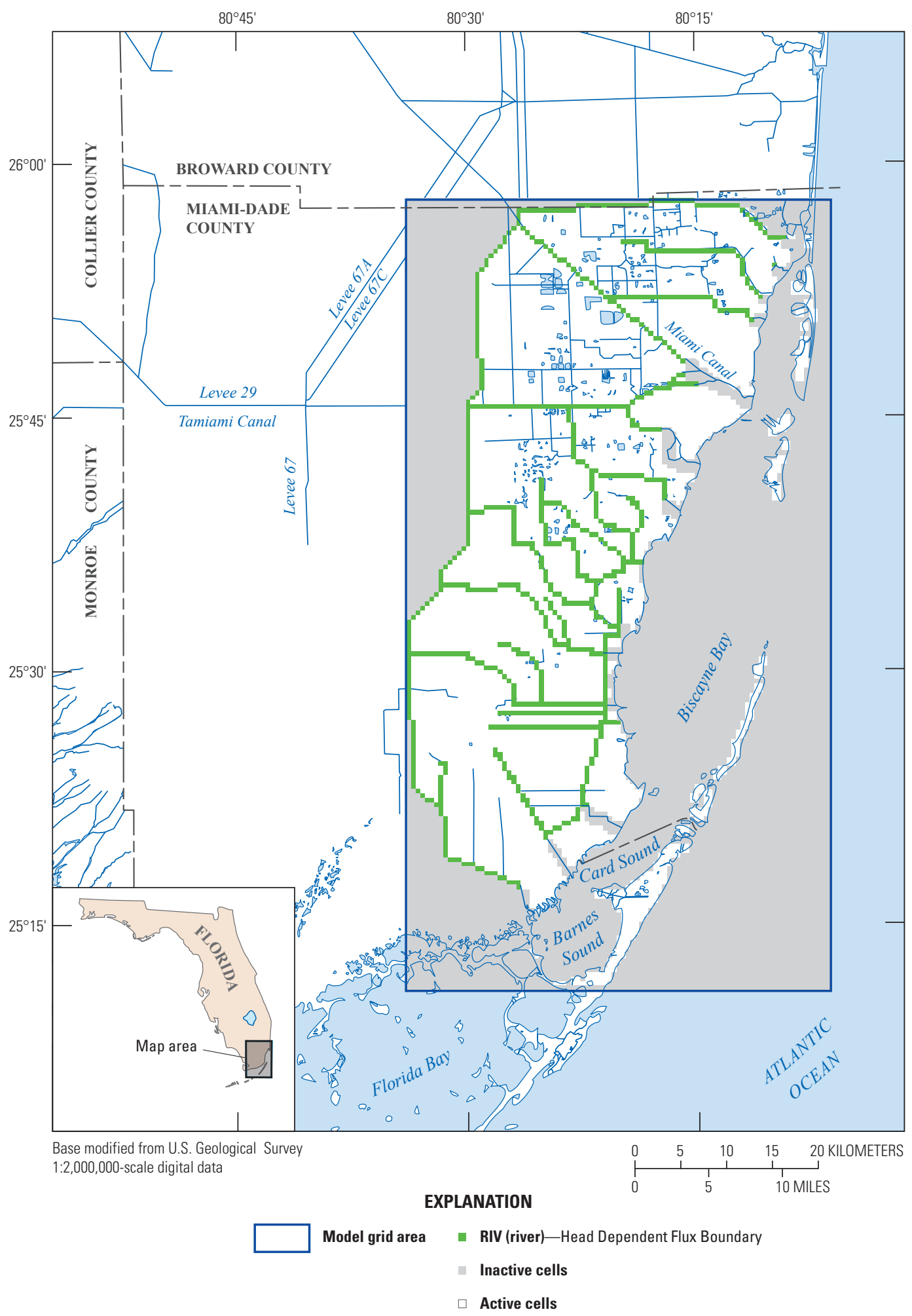

Figure 3-1. Layer 1. 


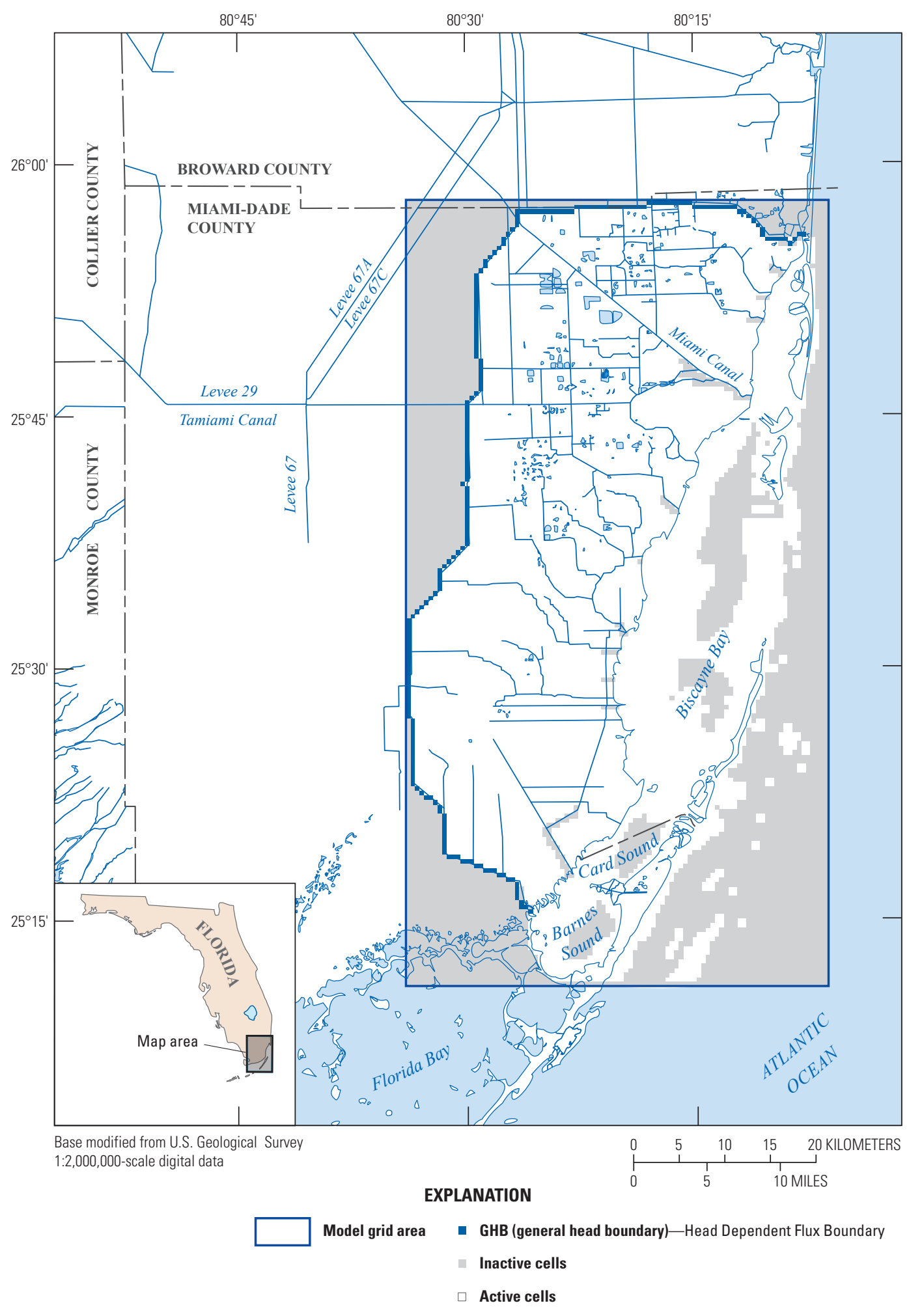

Figure 3-2. Layer 2. 


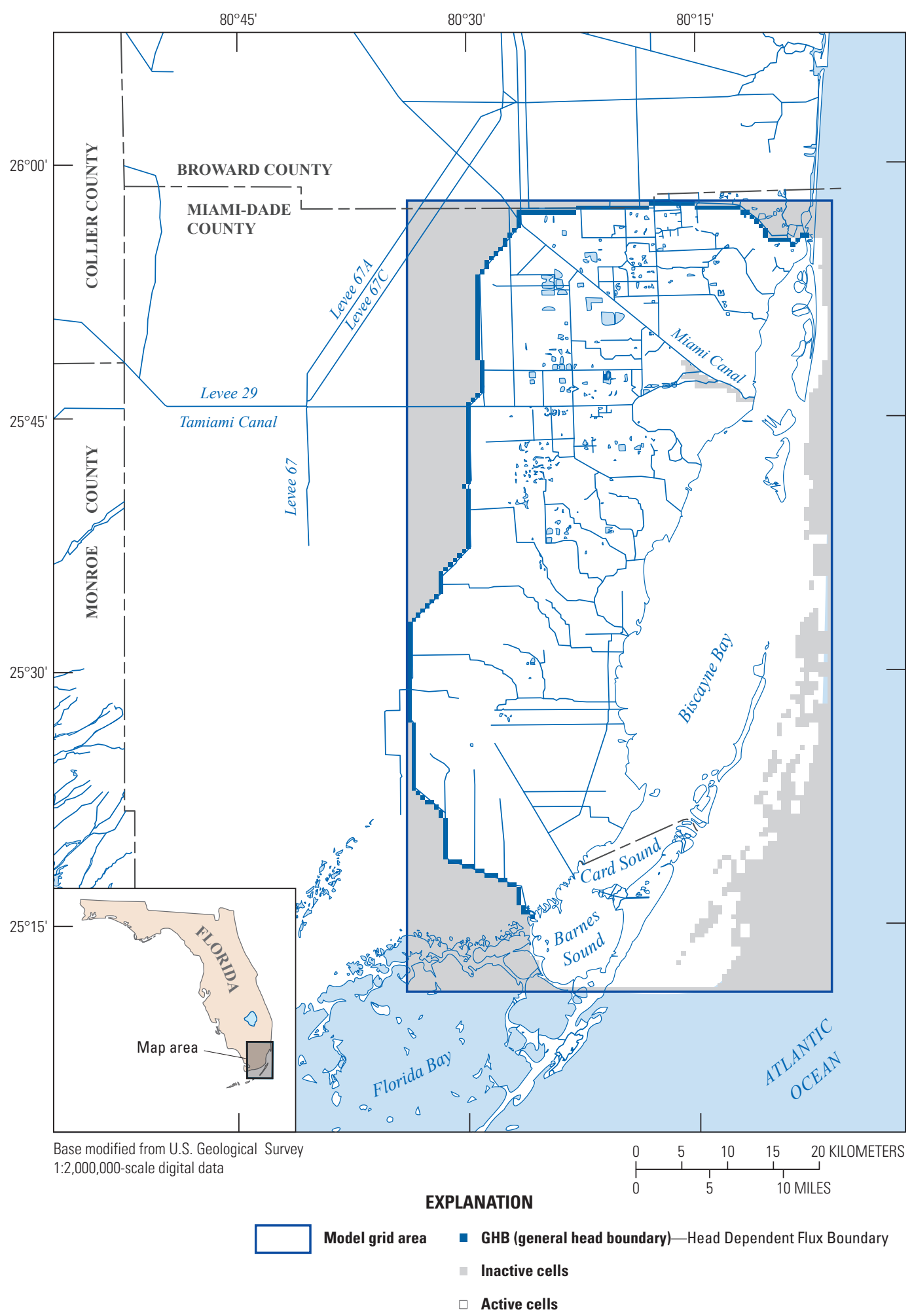

Figure 3-3. Layer 3. 


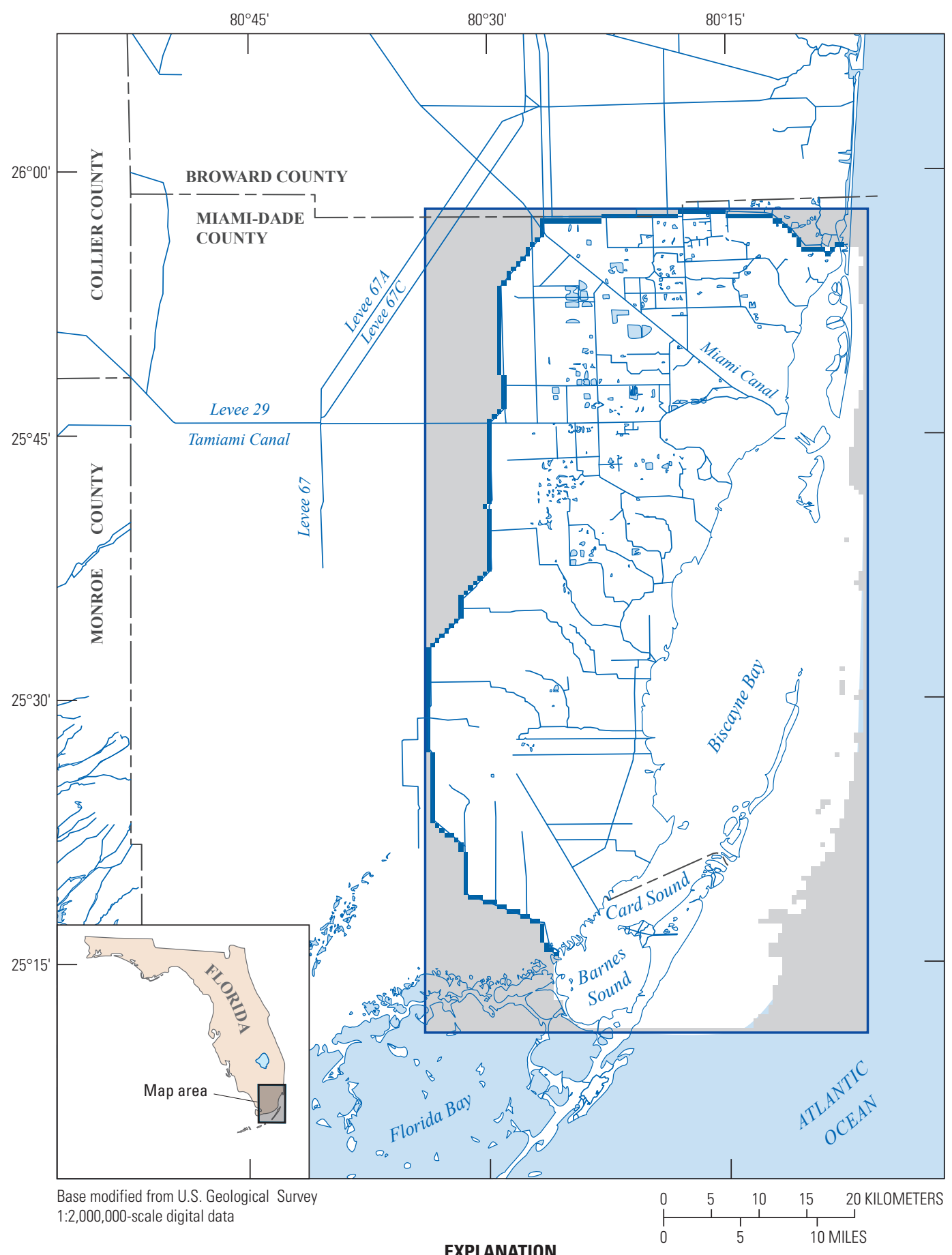

EXPLANATION

Model grid area $\quad$ GHB (general head boundary)—Head Dependent Flux Boundary

- Inactive cells

$\square$ Active cells

Figure 3-4. Layer 4. 

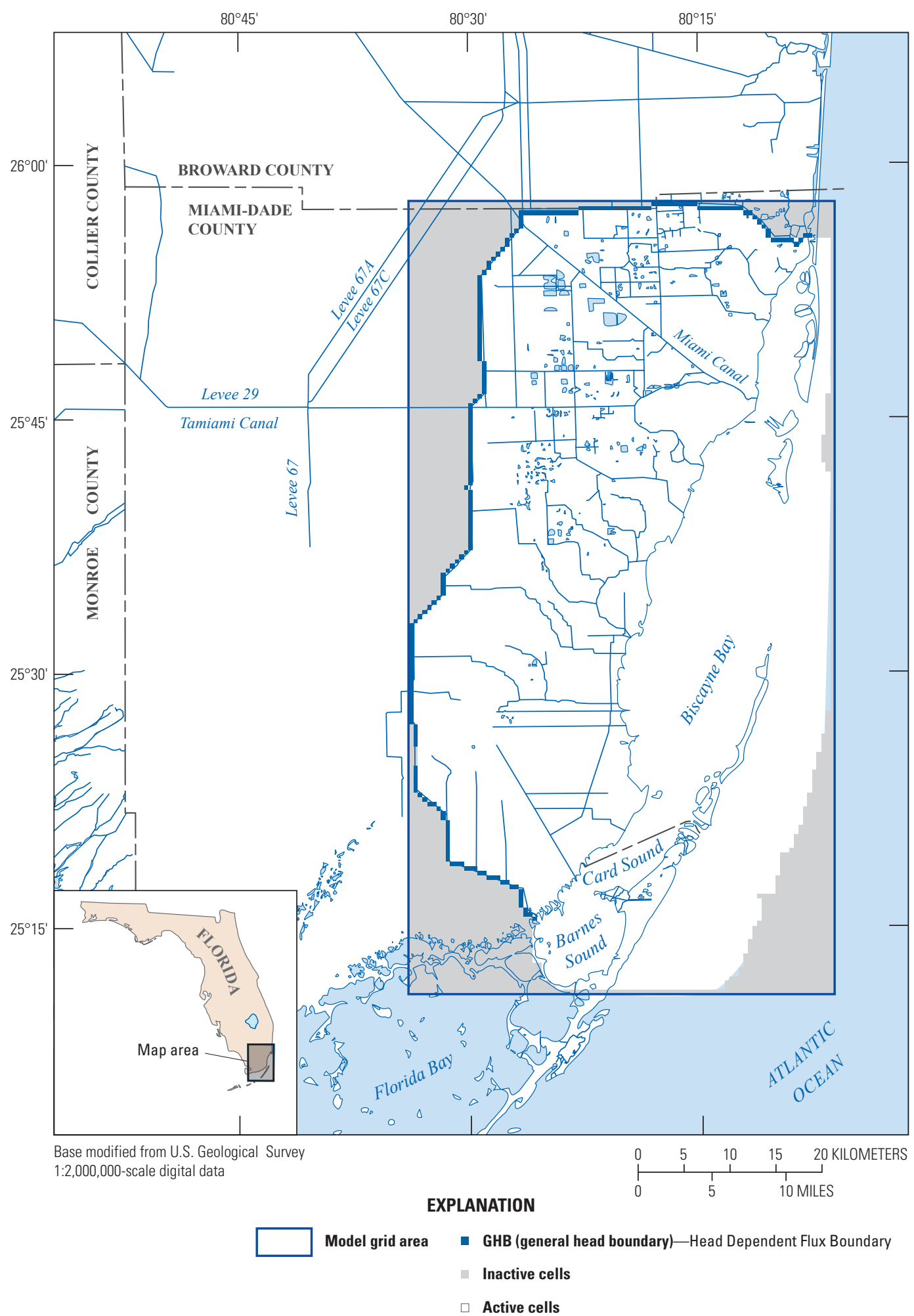

Figure 3-5. Layer 5. 


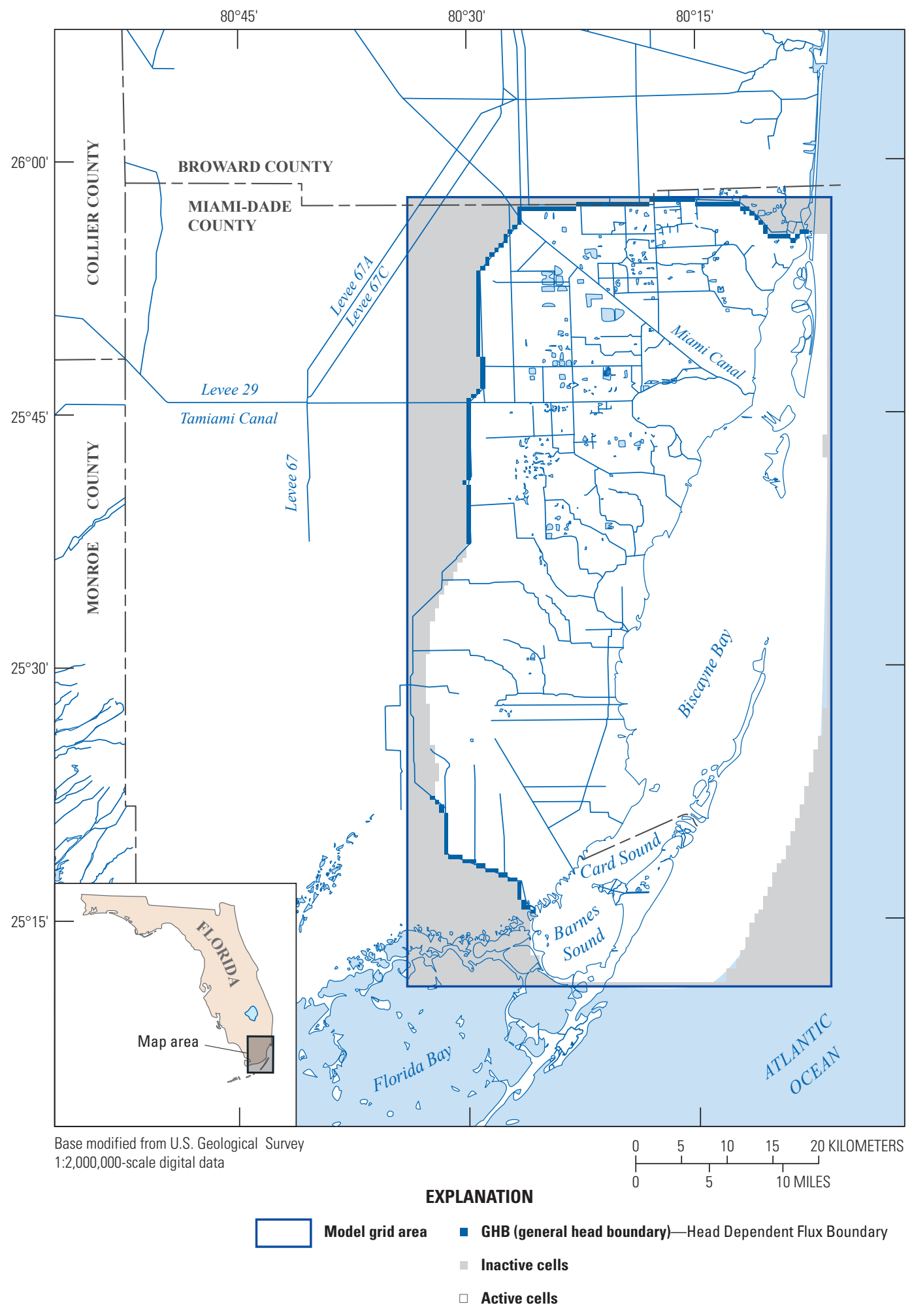

Figure 3-6. Layer 6. 


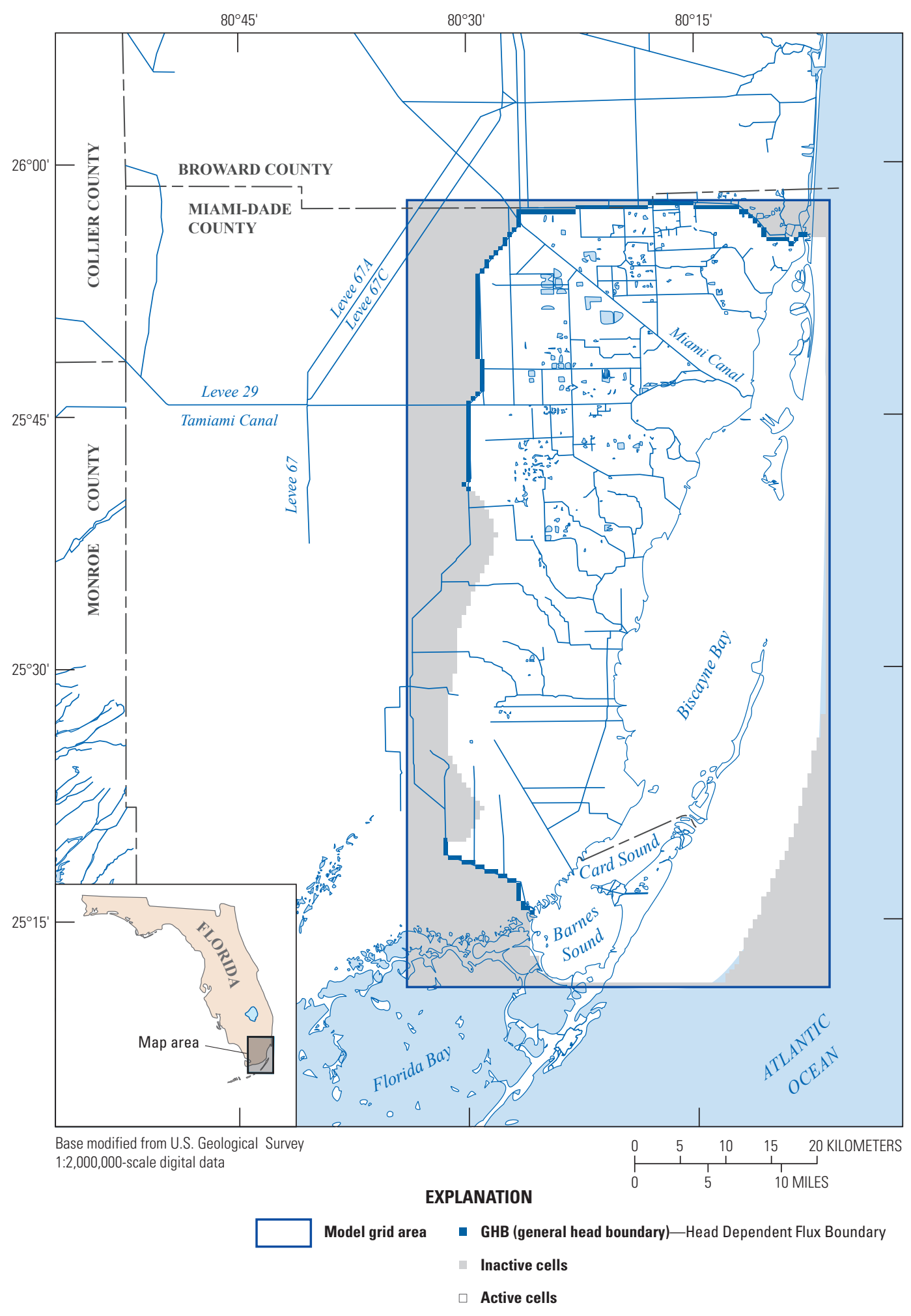

Figure 3-7. Layer 7. 


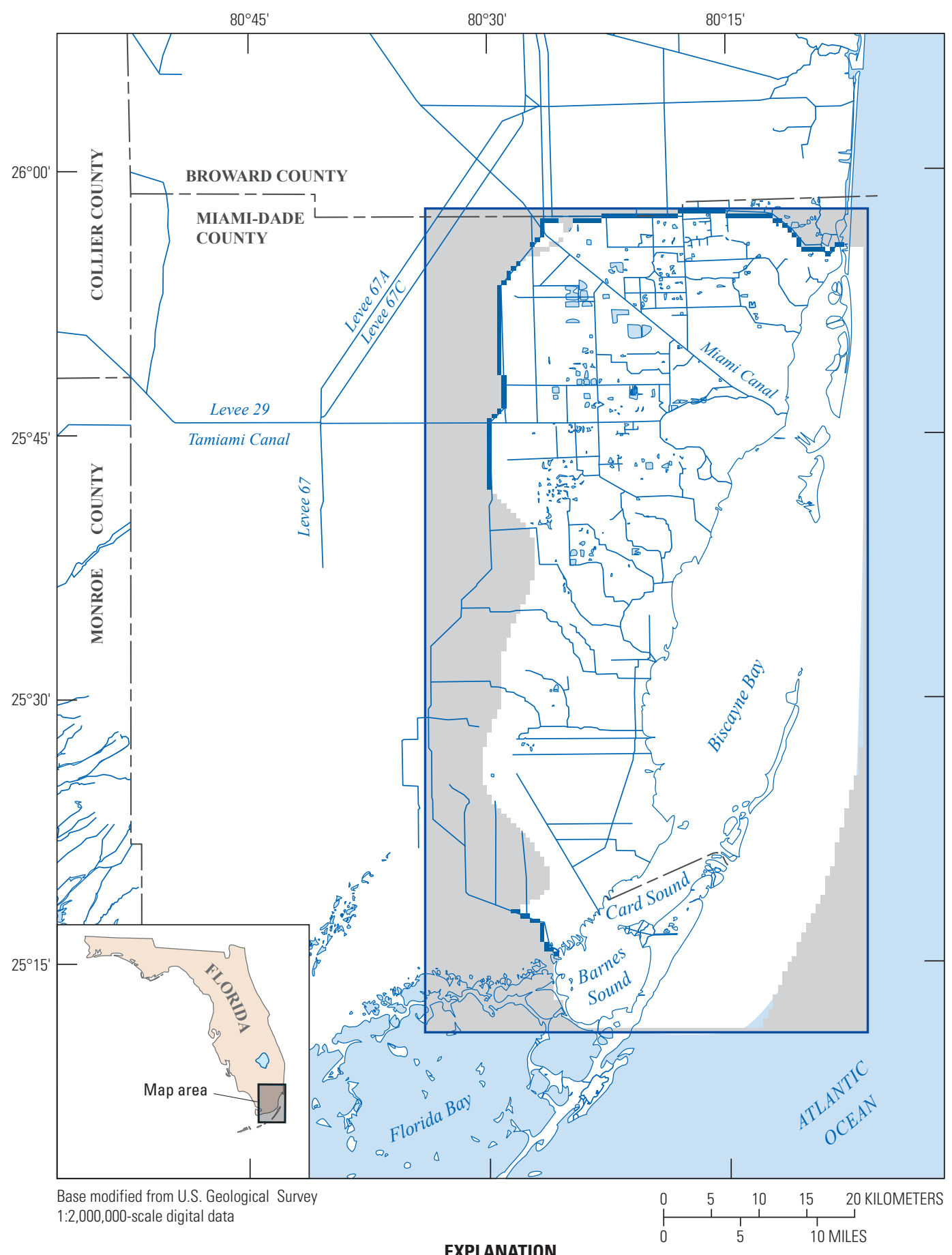

EXPLANATION

Model grid area - GHB (general head boundary)—Head Dependent Flux Boundary

- Inactive cells

Active cells

Figure 3-8. Layer 8. 


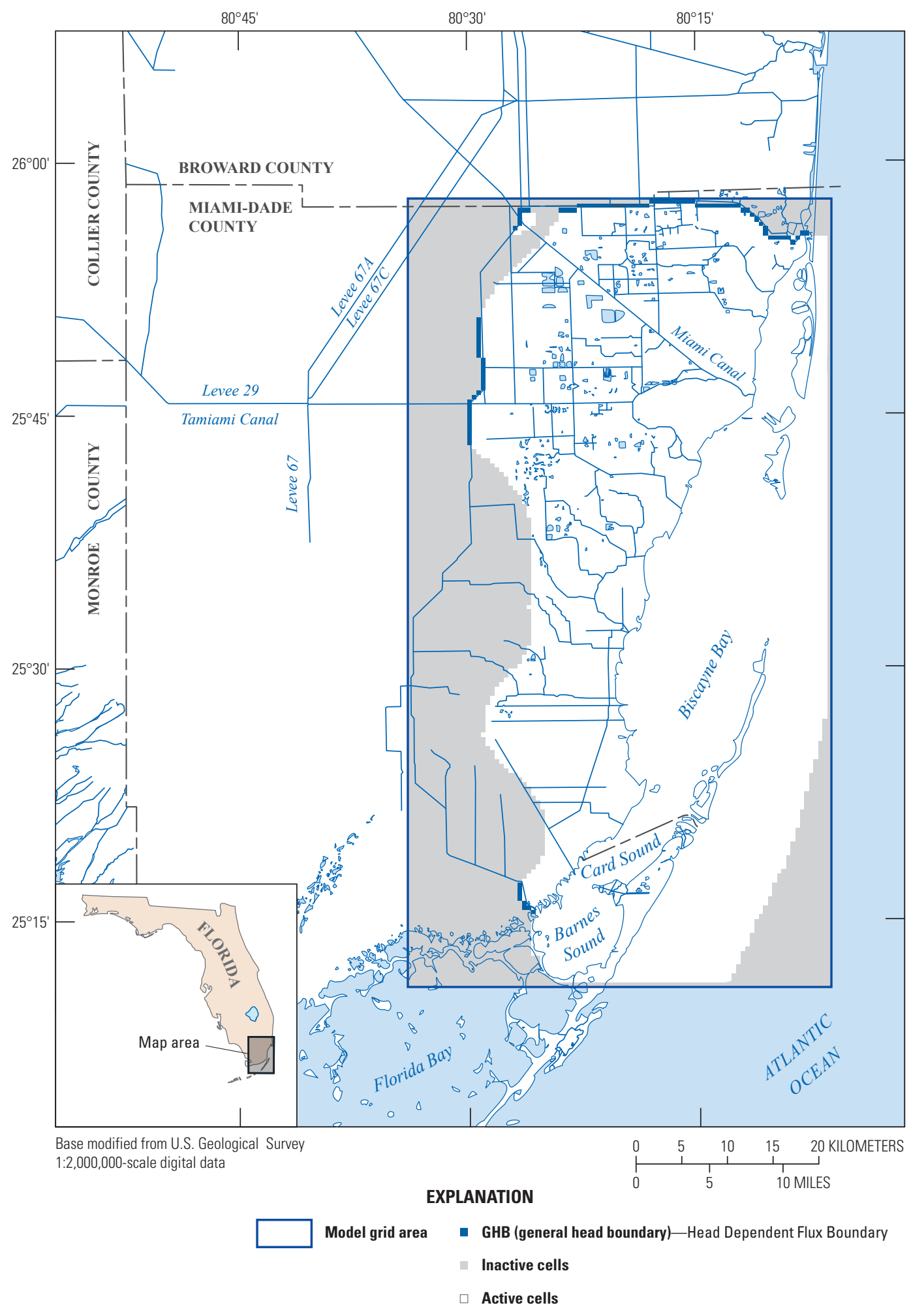

Figure 3-9. Layer 9. 


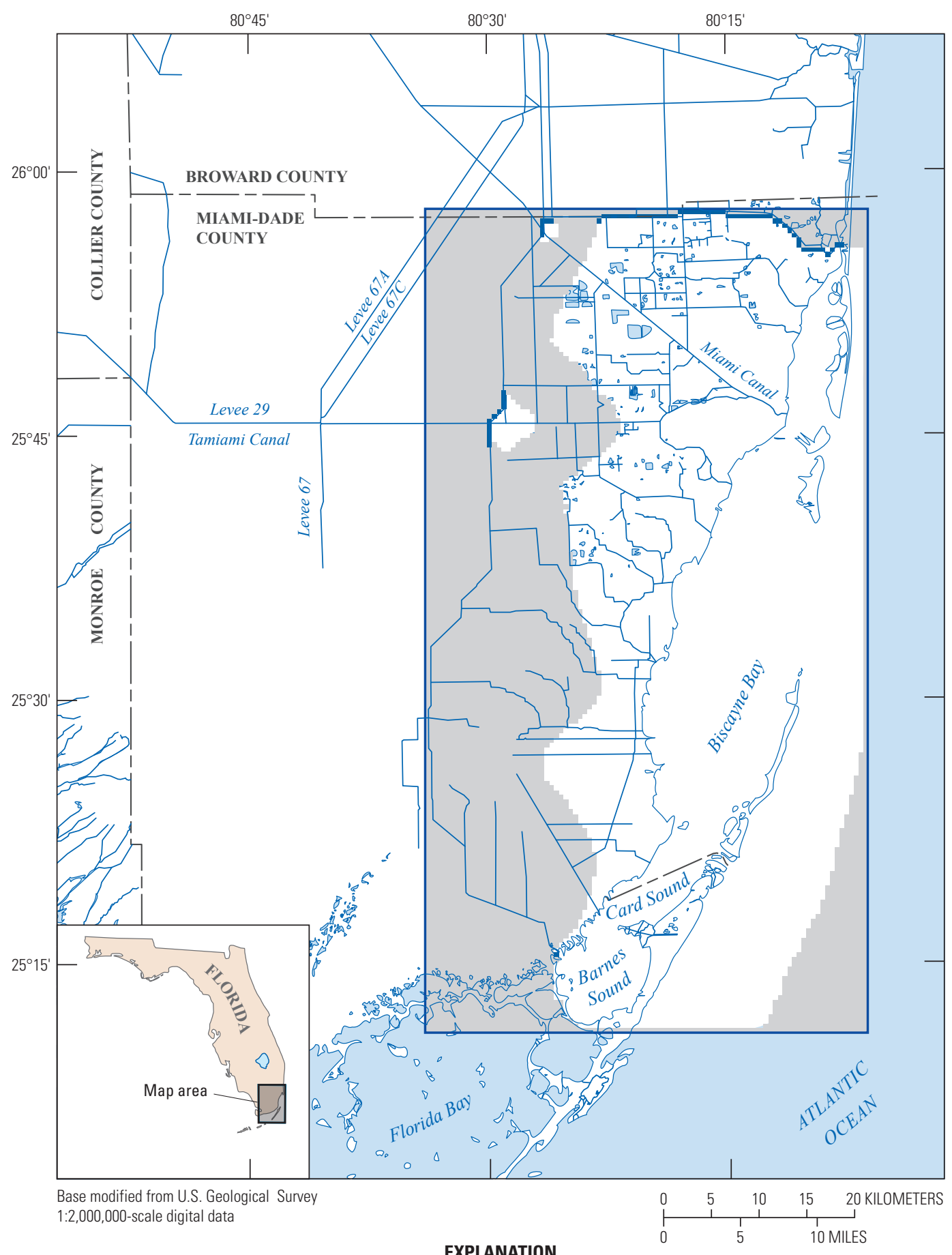

EXPLANATION

Model grid area - GHB (general head boundary)—Head Dependent Flux Boundary

Inactive cells

Active cells

Figure 3-10. Layer 10. 


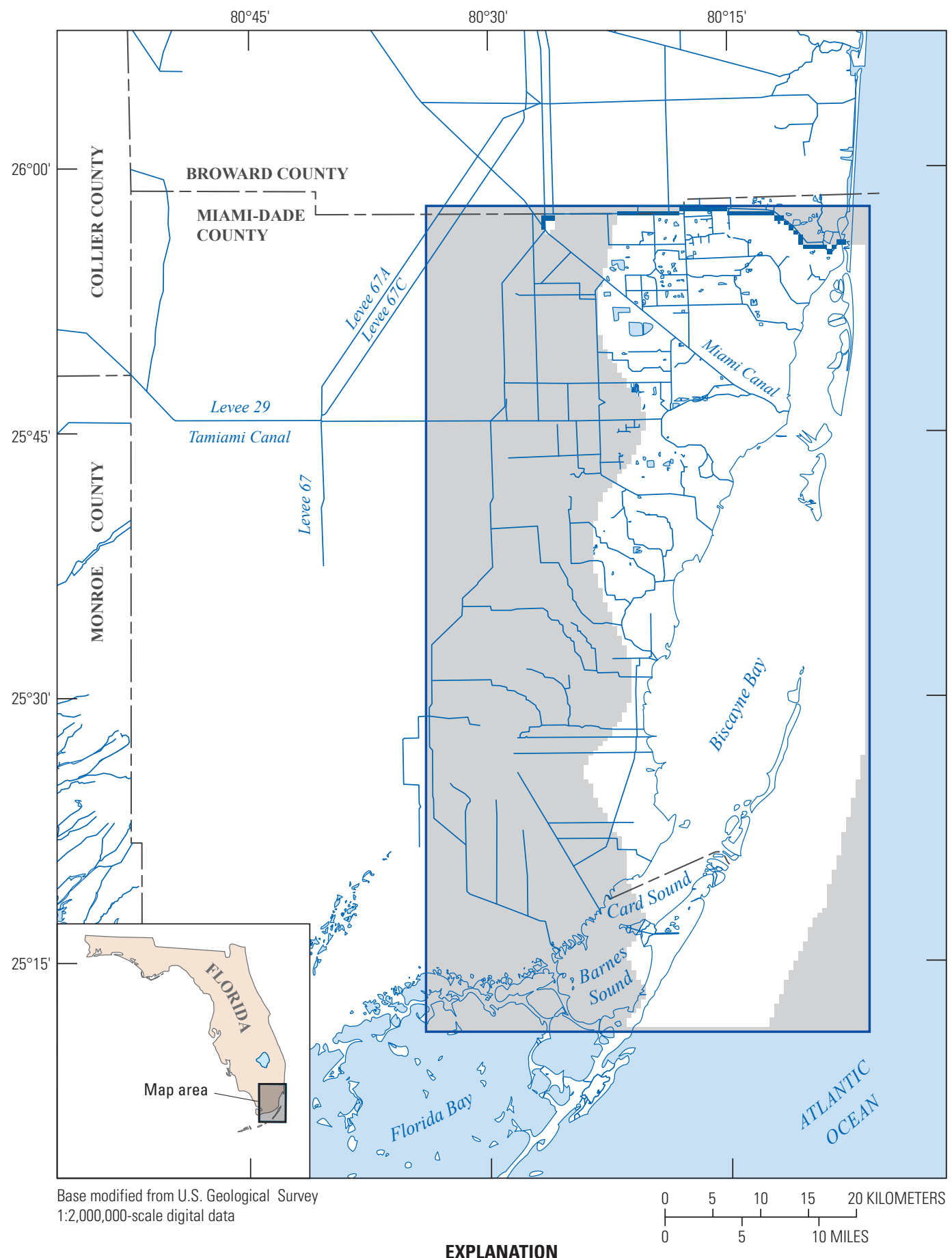

EXPLANATION

Model grid area a GHB (general head boundary)—Head Dependent Flux Boundary

III Inactive cells

$\square$ Active cells

Figure 3-11. Layer 11. 


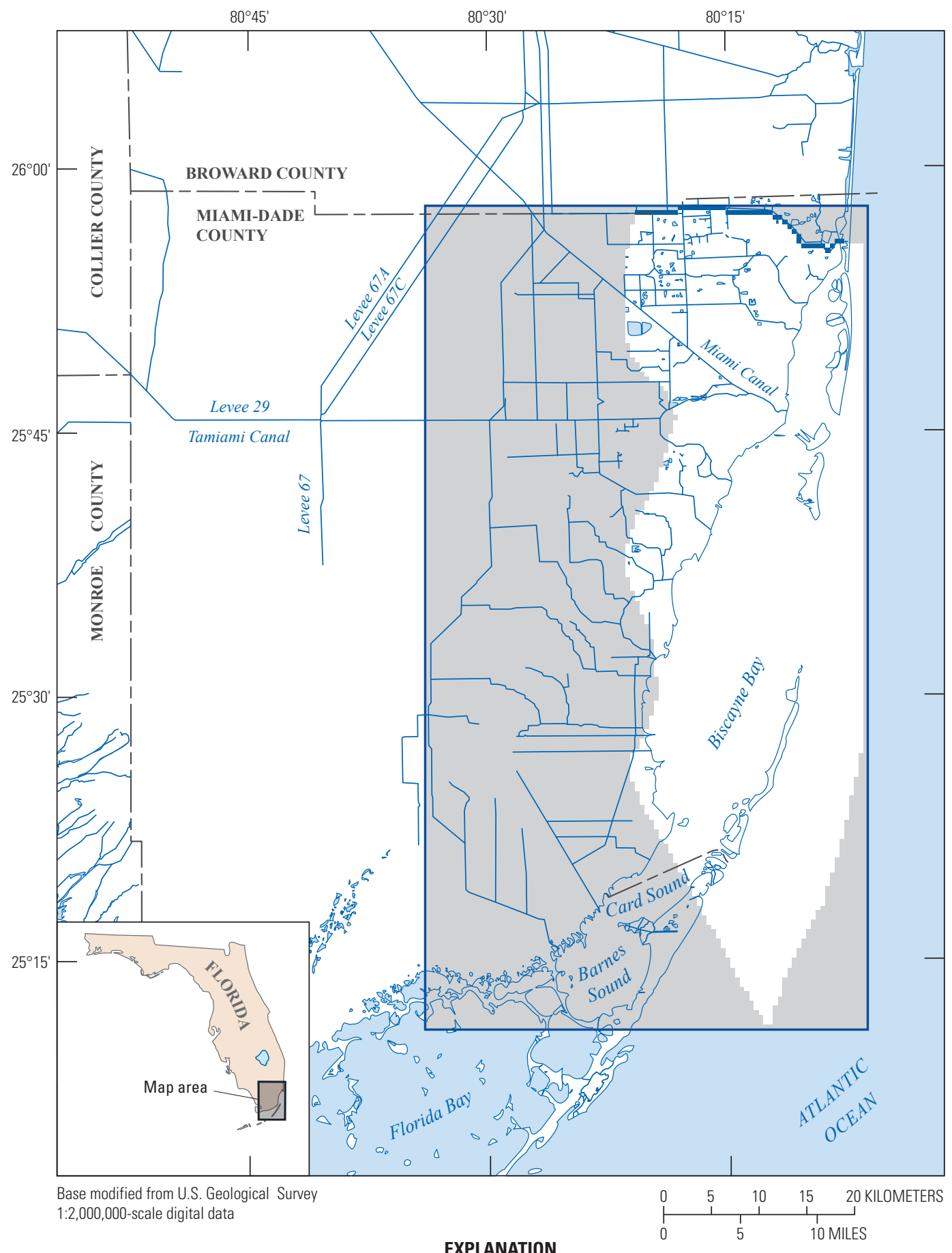

EXPLANATION

Model grid area - GHB (general head boundary)—Head Dependent Flux Boundary

- Inactive cells

Active cells

Figure 3-12. Layer 12. 


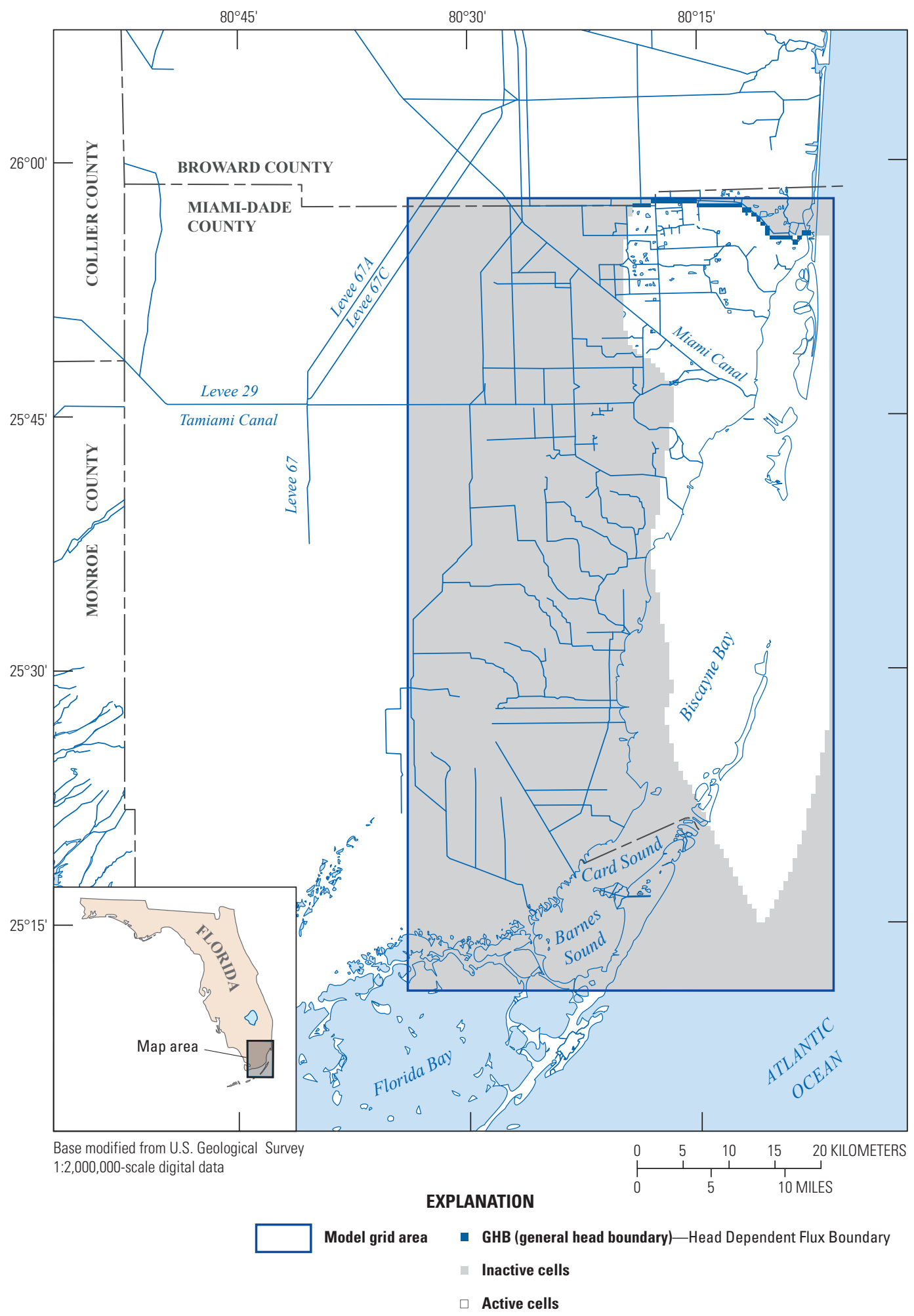

Figure 3-13. Layer 13. 


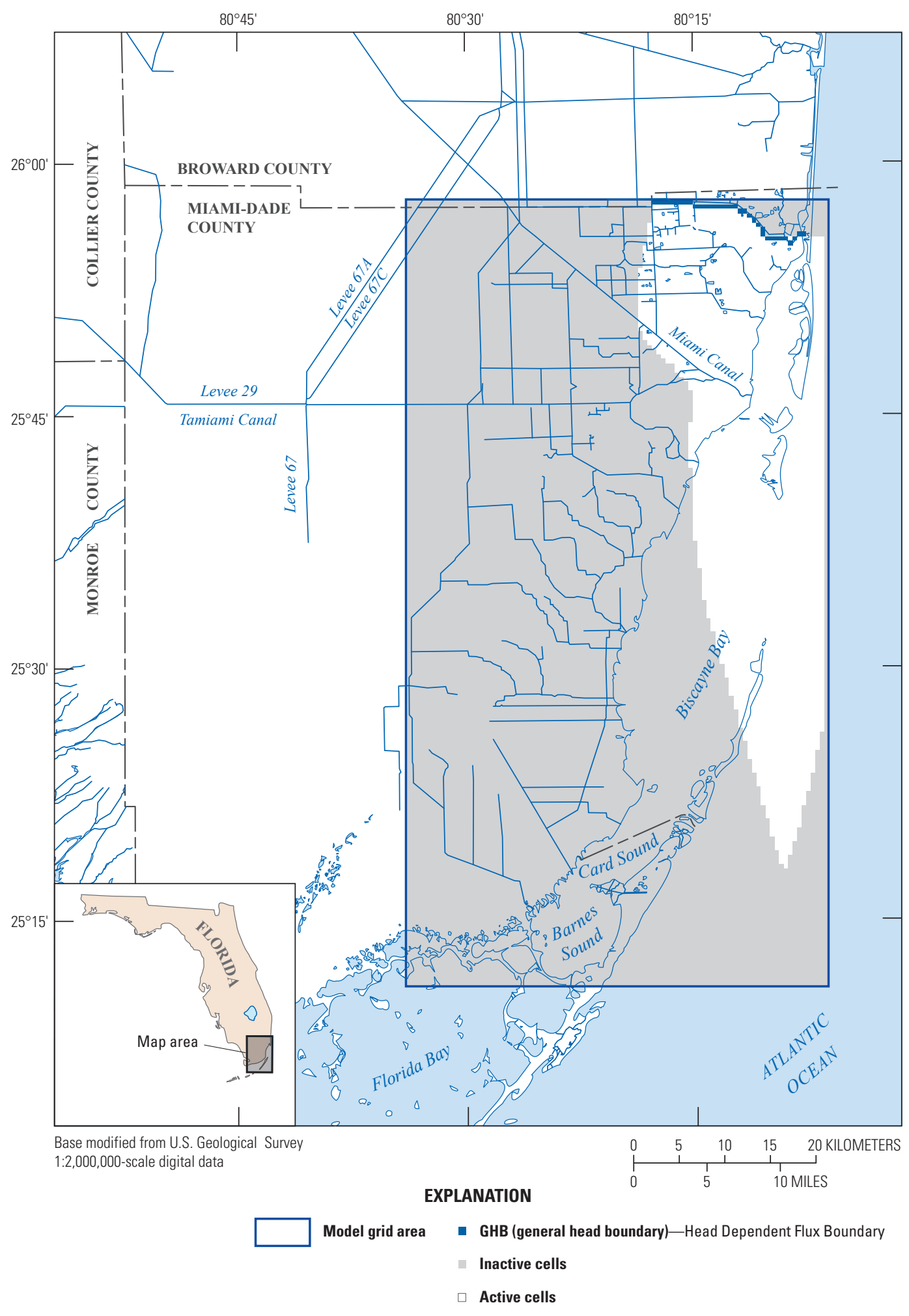

Figure 3-14. Layer 14. 


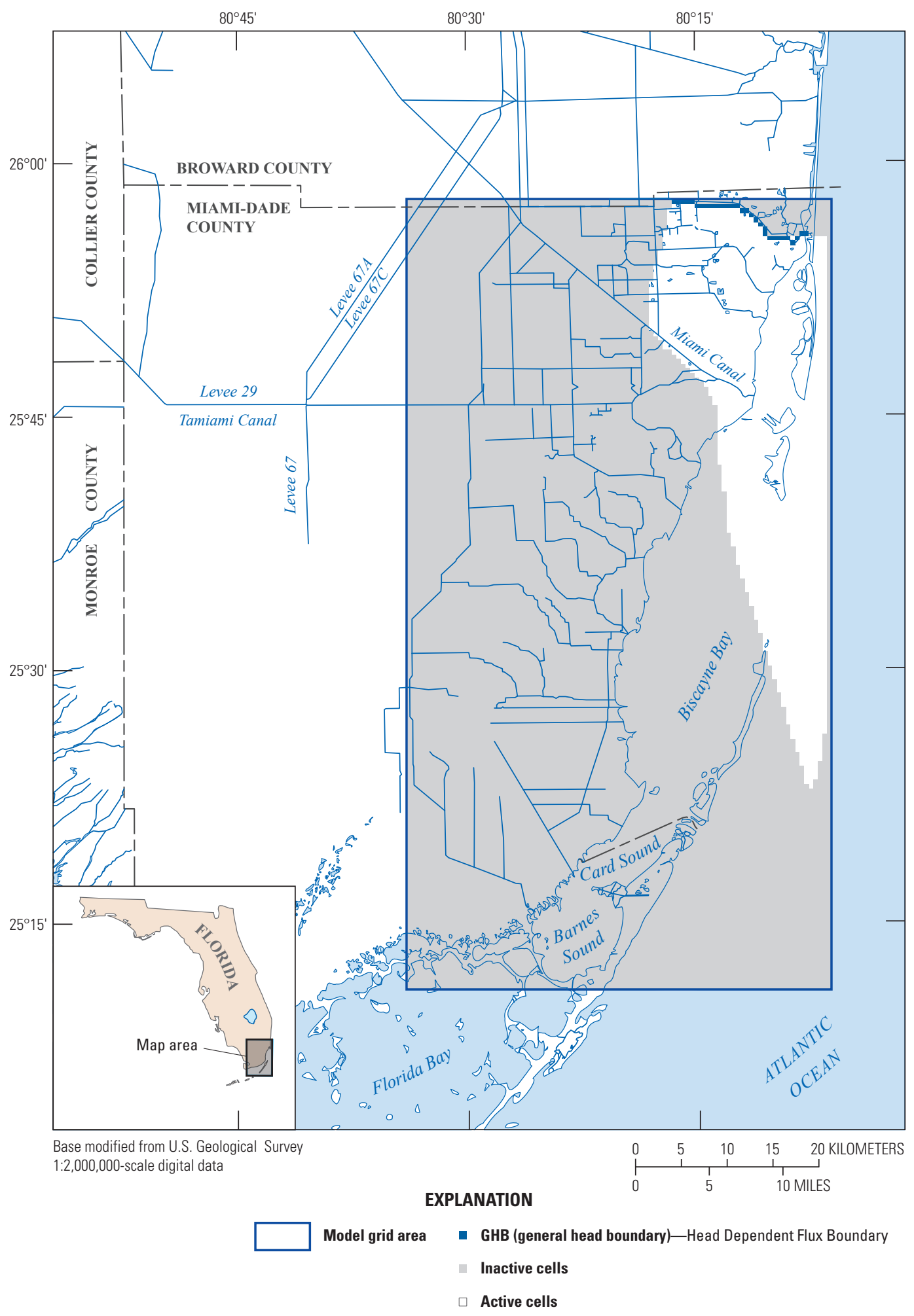

Figure 3-15. Layer 15. 


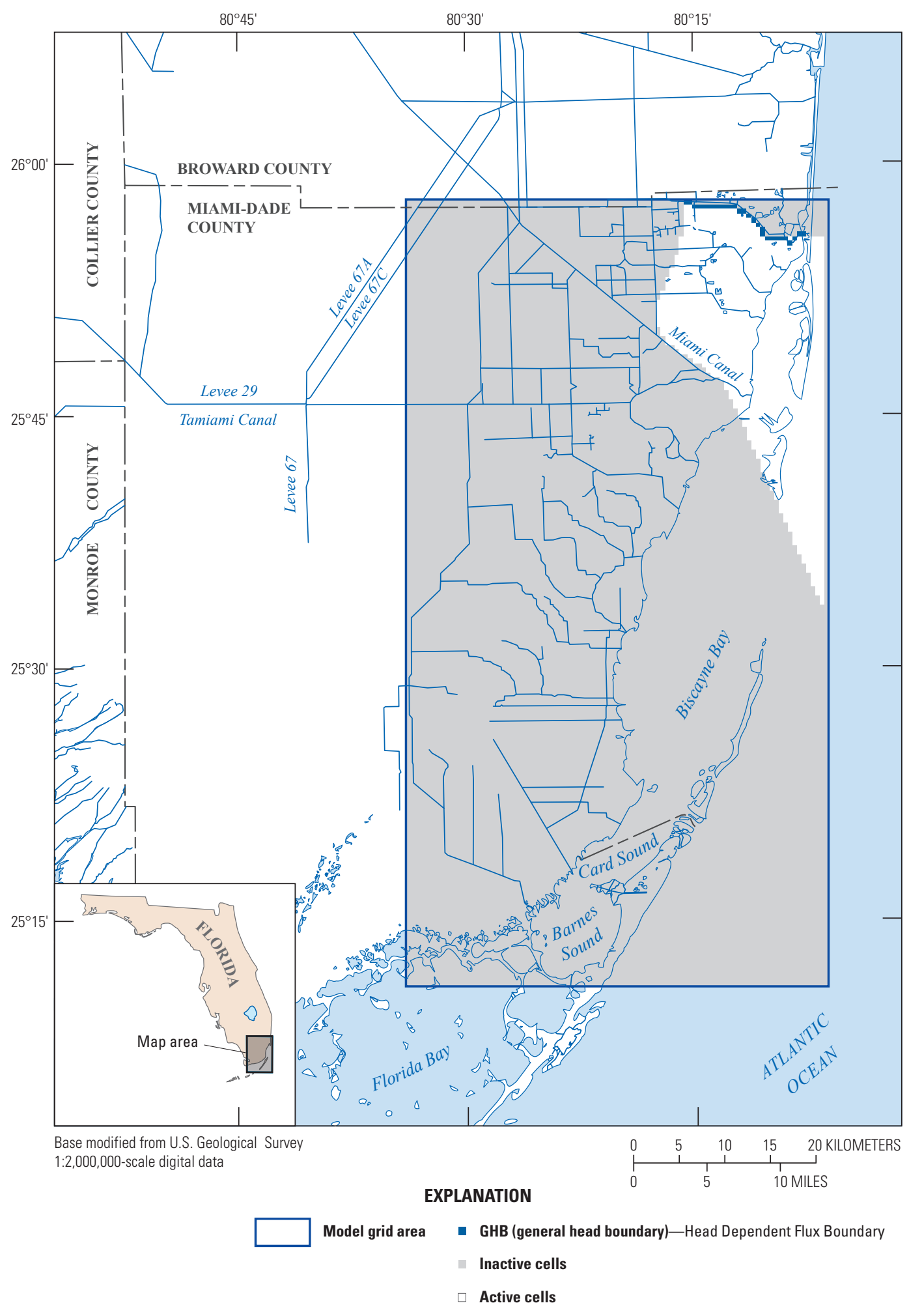

Figure 3-16. Layer 16. 


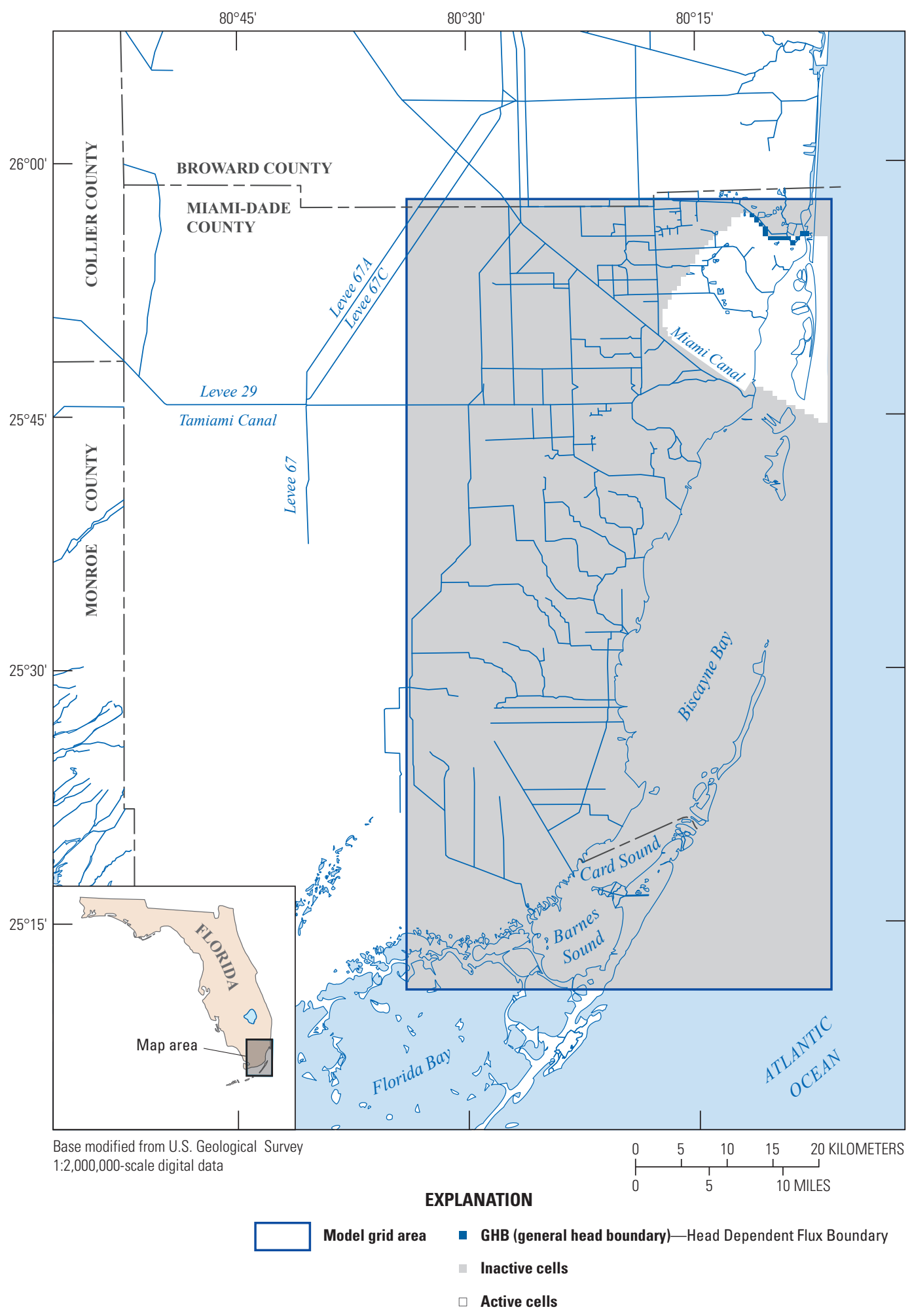

Figure 3-17. Layer 17. 


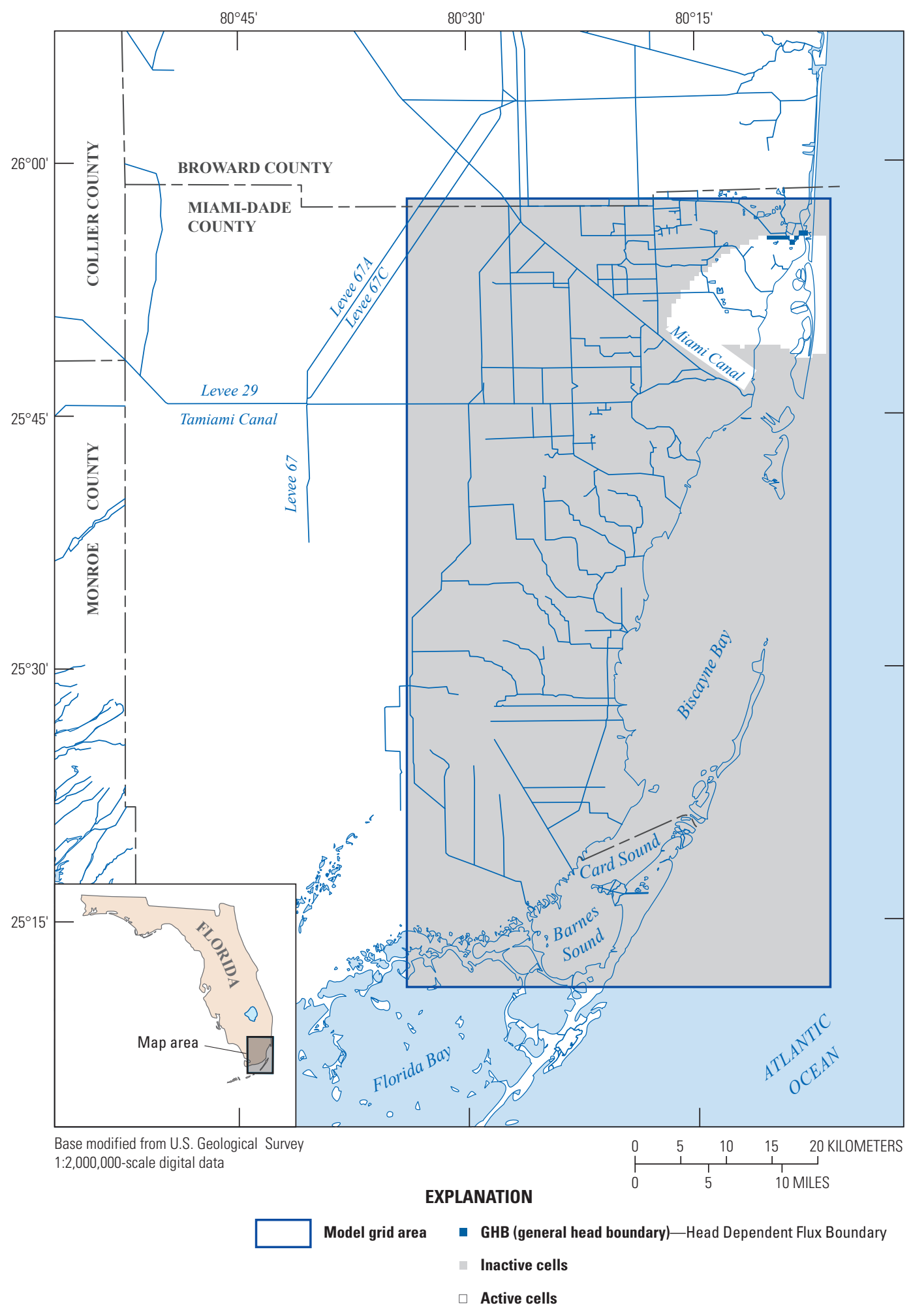

Figure 3-18. Layer 18. 


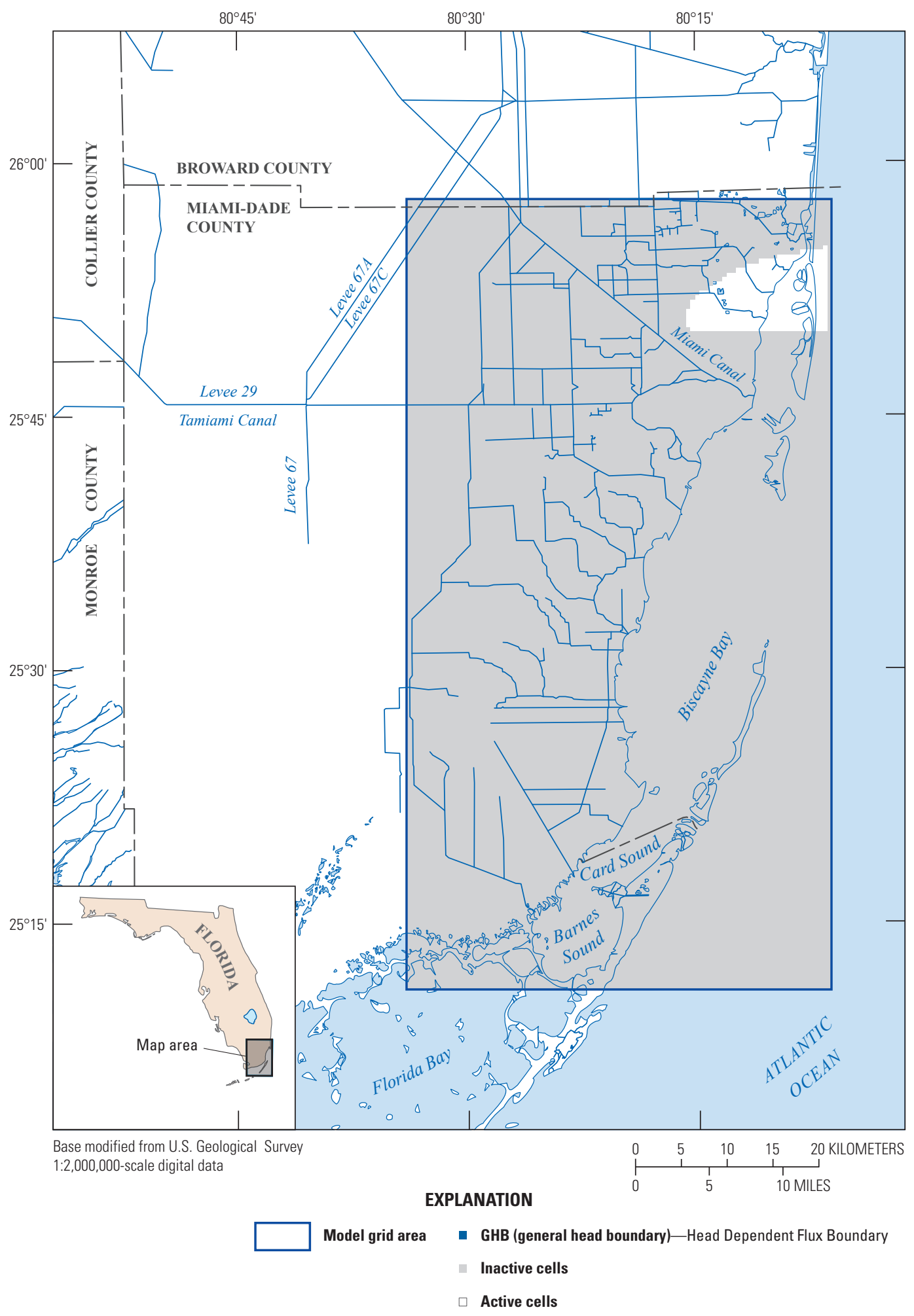

Figure 3-19. Layer 19. 


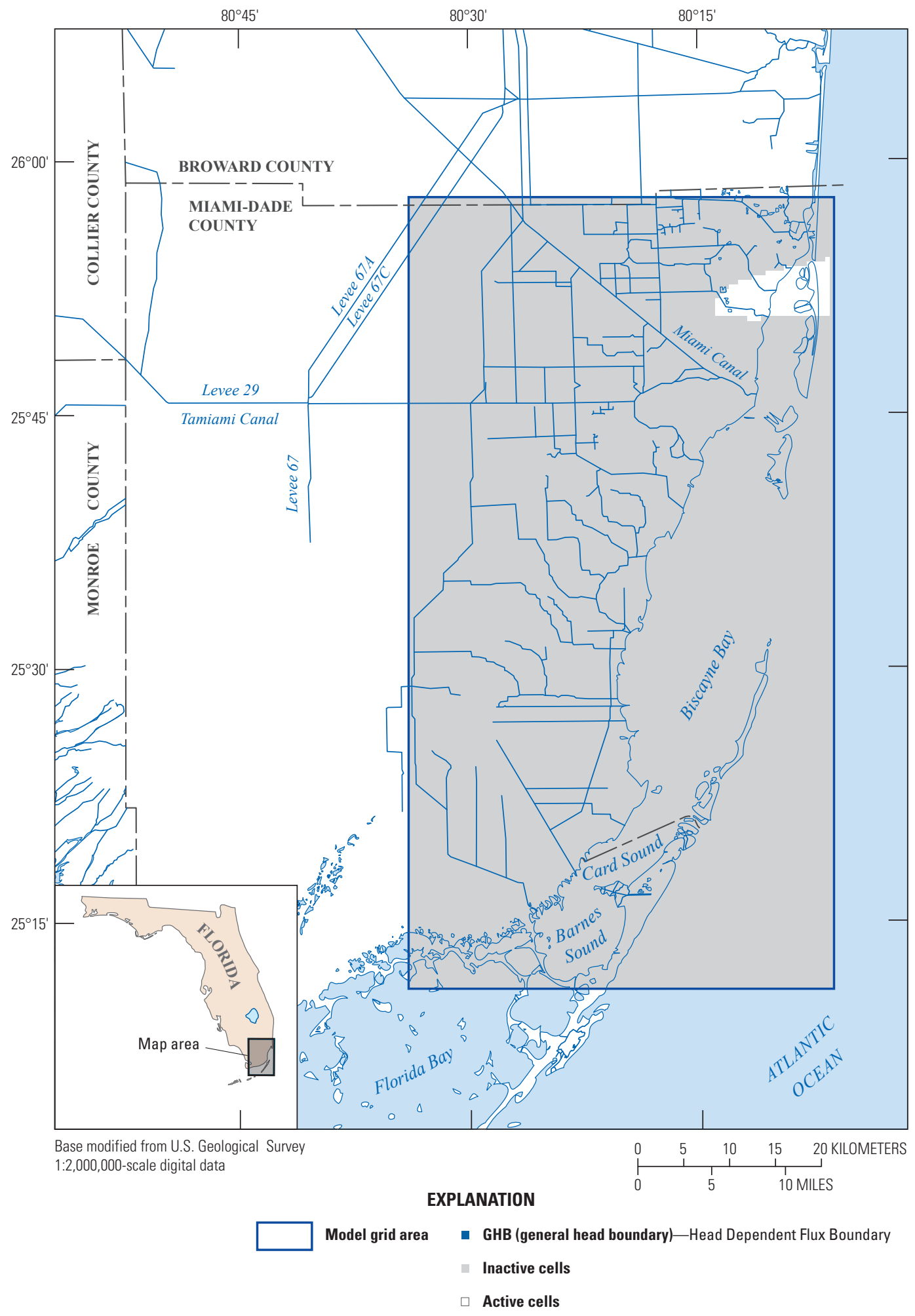

Figure 3-20. Layer 20. 


\section{Appendix 4. Temporal Data-Collection Stations Used in the Biscayne Bay Model}

Table 4-1. Rainfall stations.

[Station locations shown in figure 8. ddmmss; degrees, minutes, seconds; NOAA, National Oceanic and Atmospheric Administration; ENP, Everglades National Park; SFWMD, South Florida Water Management District]

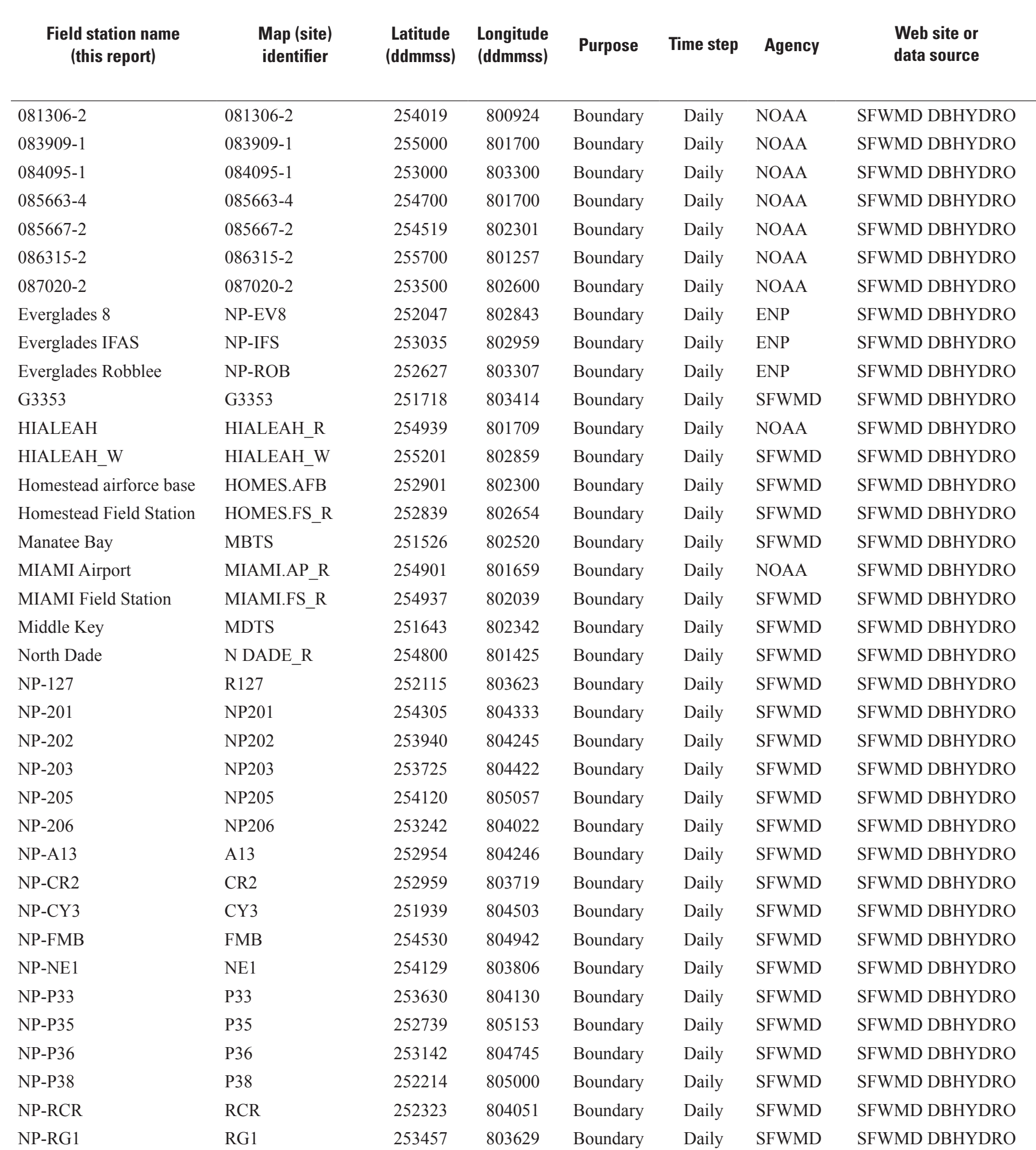


Table 4-1. Rainfall stations.-Continued

[Station locations shown in figure 8. ddmmss; degrees, minutes, seconds; NOAA, National Oceanic and Atmospheric Administration; ENP, Everglades National Park; SFWMD, South Florida Water Management District]

\begin{tabular}{|c|c|c|c|c|c|c|c|}
\hline $\begin{array}{l}\text { Field station name } \\
\text { (this report) }\end{array}$ & $\begin{array}{l}\text { Map (site) } \\
\text { identifier }\end{array}$ & $\begin{array}{l}\text { Latitude } \\
\text { (ddmmss) }\end{array}$ & $\begin{array}{l}\text { Longitude } \\
\text { (ddmmss) }\end{array}$ & Purpose & Time step & Agency & $\begin{array}{l}\text { Web site or } \\
\text { data source }\end{array}$ \\
\hline NP-RPL & RPALM & 252309 & 803538 & Boundary & Daily & SFWMD & SFWMD DBHYDRO \\
\hline PERRINE & PERRINE_R & 253601 & 802059 & Boundary & Daily & ENP & SFWMD DBHYDRO \\
\hline PERRINE_4W & PERRINE_4W & 253501 & 802559 & Boundary & Daily & NOAA & SFWMD DBHYDRO \\
\hline NP-311 & $\mathrm{R} 3110$ & 252650 & 803734 & Boundary & Daily & SFWMD & SFWMD DBHYDRO \\
\hline S123 & S123 & 253637 & 801828 & Boundary & Daily & SFWMD & SFWMD DBHYDRO \\
\hline S12D_R & S12D & 254543 & 804054 & Boundary & Daily & SFWMD & SFWMD DBHYDRO \\
\hline S165 & S165_R & 253233 & 802434 & Boundary & Daily & SFWMD & SFWMD DBHYDRO \\
\hline S167 & S167_R & 253009 & 802748 & Boundary & Daily & SFWMD & SFWMD DBHYDRO \\
\hline S174 & S174_R & 252901 & 803348 & Boundary & Daily & SFWMD & SFWMD DBHYDRO \\
\hline S177 & S177_R & 252410 & 803330 & Boundary & Daily & SFWMD & SFWMD DBHYDRO \\
\hline S179 & S179_R & 252825 & 802452 & Boundary & Daily & SFWMD & SFWMD DBHYDRO \\
\hline S18C & S18C_R & 251950 & 803130 & Boundary & Daily & SFWMD & SFWMD DBHYDRO \\
\hline S20 & $\mathrm{S} 20 \_\mathrm{R}$ & 252201 & 802235 & Boundary & Daily & SFWMD & SFWMD DBHYDRO \\
\hline $\mathrm{S} 20 \mathrm{~F}$ & S20F_R & 252746 & 802051 & Boundary & Daily & SFWMD & SFWMD DBHYDRO \\
\hline S20G & S20G_R & 252921 & 802050 & Boundary & Daily & SFWMD & SFWMD DBHYDRO \\
\hline S21 & S21_R & 253235 & 801951 & Boundary & Daily & SFWMD & SFWMD DBHYDRO \\
\hline S21A & S21A_R & 253109 & 802046 & Boundary & Daily & SFWMD & SFWMD DBHYDRO \\
\hline S26 & S26_R & 254829 & 801539 & Boundary & Daily & SFWMD & SFWMD DBHYDRO \\
\hline S27 & S27_R & 255055 & 801120 & Boundary & Daily & SFWMD & SFWMD DBHYDRO \\
\hline S28Z & S28Z_R & 255448 & 801735 & Boundary & Daily & SFWMD & SFWMD DBHYDRO \\
\hline S29 & S29_R & 255542 & 800903 & Boundary & Daily & SFWMD & SFWMD DBHYDRO \\
\hline S29Z & S29Z_R & 255743 & 801552 & Boundary & Daily & SFWMD & SFWMD DBHYDRO \\
\hline S30 & S30_R & 255724 & 802553 & Boundary & Daily & SFWMD & SFWMD DBHYDRO \\
\hline S331 & S331_R & 253639 & 803035 & Boundary & Daily & SFWMD & SFWMD DBHYDRO \\
\hline S331W & S331W & 253639 & 803035 & Boundary & Daily & SFWMD & SFWMD DBHYDRO \\
\hline S332_R & S332 & 252517 & 803524 & Boundary & Daily & SFWMD & SFWMD DBHYDRO \\
\hline S334 & S334_R & 254542 & 803008 & Boundary & Daily & SFWMD & SFWMD DBHYDRO \\
\hline S335 & S335_R & 254634 & 802858 & Boundary & Daily & SFWMD & SFWMD DBHYDRO \\
\hline S336 & S336_R & 254541 & 802948 & Boundary & Daily & SFWMD & SFWMD DBHYDRO \\
\hline S338 & S338_R & 253938 & 802849 & Boundary & Daily & SFWMD & SFWMD DBHYDRO \\
\hline Sylvania Heights & SYLVA_G & 254601 & 801659 & Boundary & Daily & SFWMD & SFWMD DBHYDRO \\
\hline Tamiami Airport & TAMI AIR_R & 253828 & 802536 & Boundary & Daily & SFWMD & SFWMD DBHYDRO \\
\hline TAMIAMI_CN & Tamiami & 254600 & 804100 & Boundary & Daily & SFWMD & SFWMD DBHYDRO \\
\hline Thursday Point & TPTS & 251223 & 802229 & Boundary & Daily & SFWMD & SFWMD DBHYDRO \\
\hline NP-TS2 & TS2 & 252359 & 803625 & Boundary & Daily & SFWMD & SFWMD DBHYDRO \\
\hline
\end{tabular}


Table 4-2. Meteorological, salinity, and water-temperature stations.

[ddmmss; degrees, minutes, seconds; NOAA, National Oceanic and Atmospheric Administration; SOFIA, South Florida Information Access; SFWMD, South Florida Water Management District; DERM, Department of Environmental Resources Management; FIU, Florida International University; USGS, U.S. Geological Survey]

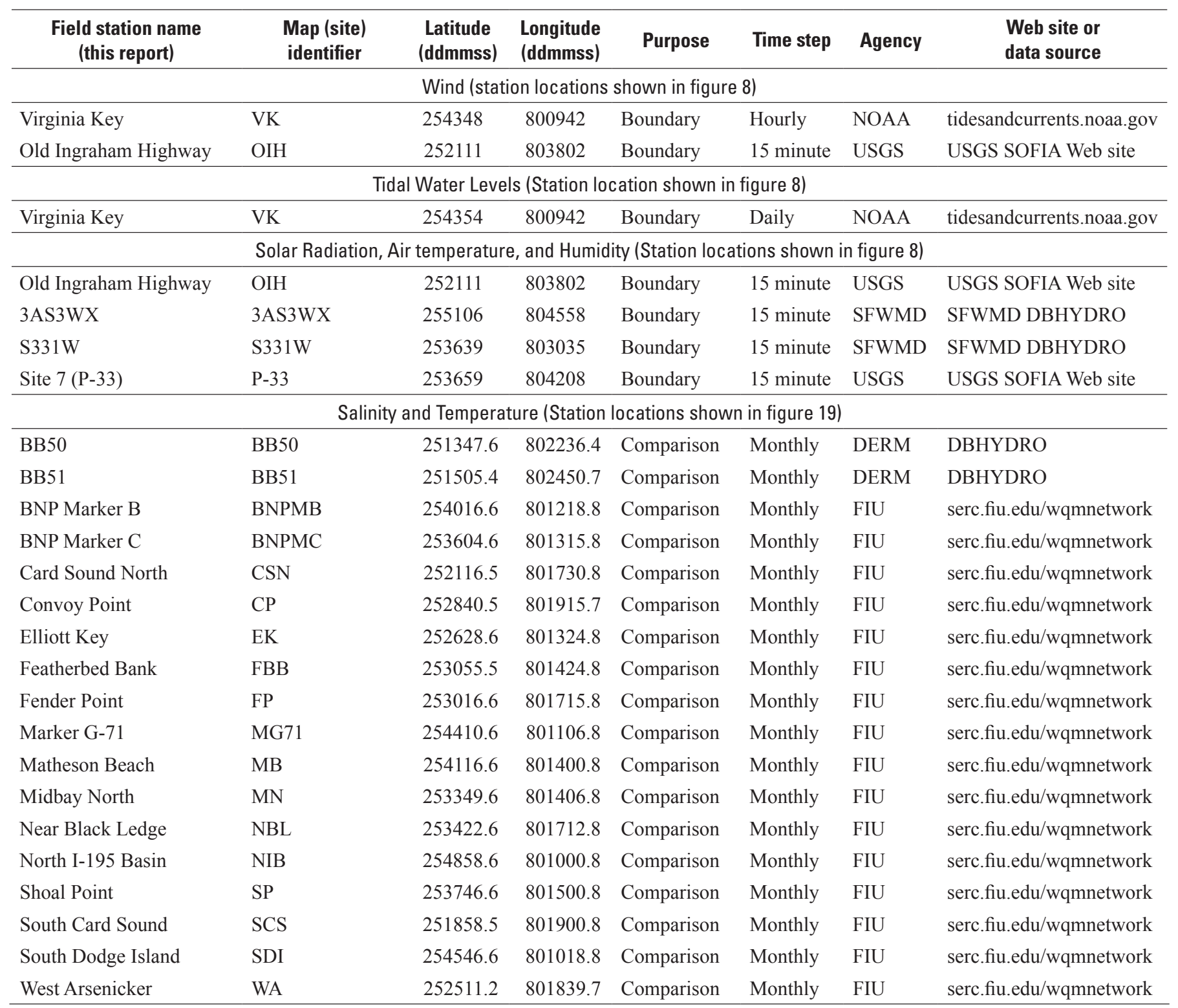


Table 4-3. Ground-water level stations.

[Station locations shown on figure 12; ddmmss; degrees, minutes, seconds; USGS, U.S. Geological Survey; NWIS, National Water Information System]

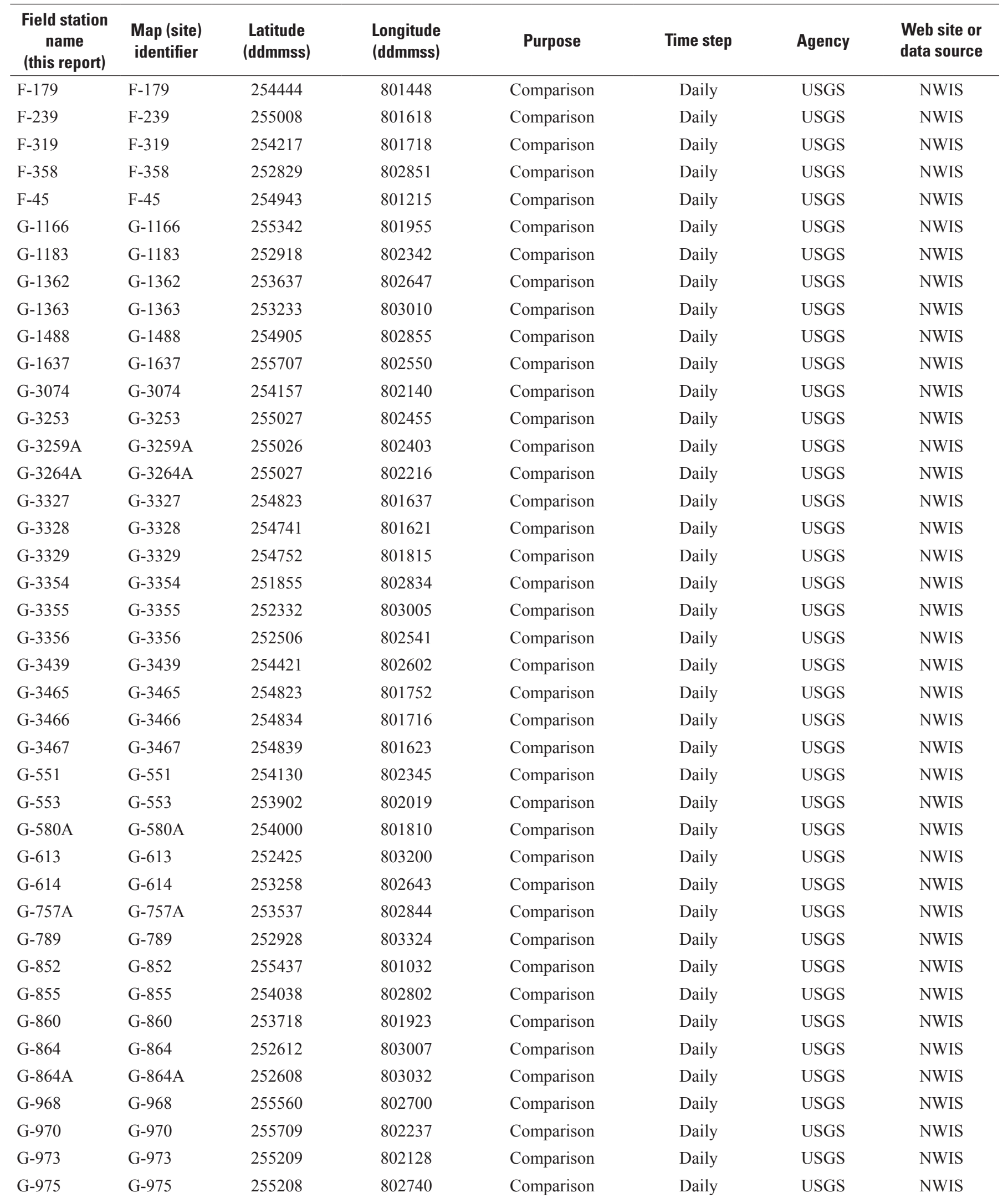


Table 4-3. Ground-water level stations.-Continued

[Station locations shown on figure 12; ddmmss; degrees, minutes, seconds; USGS, U.S. Geological Survey; NWIS, National Water Information System]

\begin{tabular}{lllllll}
\hline $\begin{array}{c}\text { Field station } \\
\text { name } \\
\text { (this report) }\end{array}$ & $\begin{array}{l}\text { Map (site) } \\
\text { identifier }\end{array}$ & $\begin{array}{c}\text { Latitude } \\
\text { (ddmmss) }\end{array}$ & $\begin{array}{c}\text { Longitude } \\
\text { (ddmmss) }\end{array}$ & Purpose & Time step & $\begin{array}{c}\text { Web site or } \\
\text { data source }\end{array}$ \\
\hline G-976 & G-976 & 254918 & 802533 & Comparison & Daily & USGS \\
S-18 & S-18 & 255526 & 801430 & Comparison & Daily & USGS \\
S-182A & S-182A & 253549 & 802141 & Comparison & Daily & NWIS \\
S-19 & S-19 & 254832 & 801750 & Comparison & Daily & NWGS \\
S-196A & S-196A & 253029 & 802956 & Comparison & Daily & NWIS \\
S-68 & S-68 & 254855 & 801710 & Comparison & Daily & NWIS \\
\hline
\end{tabular}


Table 4-4. Water levels at canal structures used for River Package.

[Station locations shown in figure 8. ddmmss; degrees, minutes, seconds; SFWMD, South Florida Water Management District]

\begin{tabular}{|c|c|c|c|c|c|c|c|}
\hline $\begin{array}{c}\text { Field station } \\
\text { name } \\
\text { (this report) }\end{array}$ & $\begin{array}{c}\text { Map (site) } \\
\text { identifier }\end{array}$ & $\begin{array}{l}\text { Latitude } \\
\text { (ddmmss) }\end{array}$ & $\begin{array}{l}\text { Longitude } \\
\text { (ddmmss) }\end{array}$ & Purpose & Time step & Agency & $\begin{array}{l}\text { Web site or } \\
\text { data source }\end{array}$ \\
\hline G-119 & G119_H,G119_T & 253833 & 802018 & Boundary & Daily & SFWMD & SFWMD DBHYDRO \\
\hline G-211 & G211_H,G211_T & 253931 & 802952 & Boundary & Daily & SFWMD & SFWMD DBHYDRO \\
\hline G-58 & G58_H,G58_T & 255400 & 800943 & Boundary & Daily & SFWMD & SFWMD DBHYDRO \\
\hline G-72 & G72_H,G72_T & 255209 & 802021 & Boundary & Daily & SFWMD & SFWMD DBHYDRO \\
\hline G-93 & G93_H,G93_T & 254418 & 801712 & Boundary & Daily & SFWMD & SFWMD DBHYDRO \\
\hline S-118 & S118_H,S118_T & 253722 & 802030 & Boundary & Daily & SFWMD & SFWMD DBHYDRO \\
\hline S-119 & S119_H,S119_T & 253833 & 802018 & Boundary & Daily & SFWMD & SFWMD DBHYDRO \\
\hline S-120 & $\mathrm{S} 120 \_\mathrm{T}$ & 254015 & 801917 & Boundary & Daily & SFWMD & SFWMD DBHYDRO \\
\hline S-121 & $\mathrm{S} 121 \_\mathrm{H}, \mathrm{S} 121 \_\mathrm{T}$ & 254113 & 802139 & Boundary & Daily & SFWMD & SFWMD DBHYDRO \\
\hline S-122 & $\mathrm{S} 122 \_\mathrm{H}, \mathrm{S} 122 \_\mathrm{T}$ & 253539 & 802053 & Boundary & Daily & SFWMD & SFWMD DBHYDRO \\
\hline S-123 & $\mathrm{S} 123 \_\mathrm{H}, \mathrm{S} 123 \_\mathrm{T}$ & 253637 & 801828 & Boundary & Daily & SFWMD & SFWMD DBHYDRO \\
\hline S-148 & S148_H,S148_T & 253412 & 802258 & Boundary & Daily & SFWMD & SFWMD DBHYDRO \\
\hline S-149 & S149_H & 253531 & 802140 & Boundary & Daily & SFWMD & SFWMD DBHYDRO \\
\hline S-165 & $\mathrm{S} 165 \_\mathrm{H}, \mathrm{S} 165 \_\mathrm{T}$ & 253233 & 802434 & Boundary & Daily & SFWMD & SFWMD DBHYDRO \\
\hline S-166 & S166_H,S166_T & 253106 & 802556 & Boundary & Daily & SFWMD & SFWMD DBHYDRO \\
\hline S-167 & S167_H,S167_T & 253009 & 802748 & Boundary & Daily & SFWMD & SFWMD DBHYDRO \\
\hline S-176 & S176_H,S176_T & 252858 & 803346 & Boundary & Daily & SFWMD & SFWMD DBHYDRO \\
\hline S-177 & S177_H,S177_T & 252410 & 803330 & Boundary & Daily & SFWMD & SFWMD DBHYDRO \\
\hline S-178 & S178_T & 252429 & 803126 & Boundary & Daily & SFWMD & SFWMD DBHYDRO \\
\hline S-179 & S179_H,S179_T & 252825 & 802452 & Boundary & Daily & SFWMD & SFWMD DBHYDRO \\
\hline S-18C & S18C_H,S18C_T & 251950 & 803130 & Boundary & Daily & SFWMD & SFWMD DBHYDRO \\
\hline S-194 & S194_H,S194_T & 253459 & 802842 & Boundary & Daily & SFWMD & SFWMD DBHYDRO \\
\hline S-195 & S195_H,S195_T & 253304 & 802346 & Boundary & Daily & SFWMD & SFWMD DBHYDRO \\
\hline S-196 & S196_H,S196_T & 253101 & 803041 & Boundary & Daily & SFWMD & SFWMD DBHYDRO \\
\hline S-197 & S197_H,S197_T & 251713 & 802629 & Boundary & Daily & SFWMD & SFWMD DBHYDRO \\
\hline S-20 & S20_H,S20_T & 252201 & 802235 & Boundary & Daily & SFWMD & SFWMD DBHYDRO \\
\hline S-20F & $\mathrm{S} 20 \mathrm{~F} \_\mathrm{H}, \mathrm{S} 20 \mathrm{~F} \_\mathrm{T}$ & 252746 & 802051 & Boundary & Daily & SFWMD & SFWMD DBHYDRO \\
\hline S-20G & S20G_H,S20G_T & 252921 & 802050 & Boundary & Daily & SFWMD & SFWMD DBHYDRO \\
\hline S-21 & $\mathrm{S} 21 \_\mathrm{H}, \mathrm{S} 21 \_\mathrm{T}$ & 253235 & 801951 & Boundary & Daily & SFWMD & SFWMD DBHYDRO \\
\hline S-21A & S21A_H,S21A_T & 253109 & 802046 & Boundary & Daily & SFWMD & SFWMD DBHYDRO \\
\hline S-22 & $\mathrm{S} 22 \_\mathrm{H}, \mathrm{S} 22{ }_{-} \mathrm{T}$ & 254012 & 801702 & Boundary & Daily & SFWMD & SFWMD DBHYDRO \\
\hline S-25 & $\mathrm{S} 25 \_\mathrm{H}, \mathrm{S} 25 \_\mathrm{T}$ & 254752 & 801444 & Boundary & Daily & SFWMD & SFWMD DBHYDRO \\
\hline$S-25 B$ & S25B_H,S25B_T & 254738 & 801545 & Boundary & Daily & SFWMD & SFWMD DBHYDRO \\
\hline S-26 & S26_H,S26_T & 254829 & 801539 & Boundary & Daily & SFWMD & SFWMD DBHYDRO \\
\hline S-27 & S27_H,S27_T & 255055 & 801120 & Boundary & Daily & SFWMD & SFWMD DBHYDRO \\
\hline S-28 & $\mathrm{S} 28 \_\mathrm{H}, \mathrm{S} 28 \_\mathrm{T}$ & 255215 & 801042 & Boundary & Daily & SFWMD & SFWMD DBHYDRO \\
\hline S-29 & S29_H,S29_T & 255542 & 800903 & Boundary & Daily & SFWMD & SFWMD DBHYDRO \\
\hline $\mathrm{S}-30$ & S30_H,S30_T & 255724 & 802553 & Boundary & Daily & SFWMD & SFWMD DBHYDRO \\
\hline
\end{tabular}


Manuscript approved on May 18, 2012

For more information about this publication, contact: Melinda Lohmann, Hydrologist USGS Florida Water Science Center 7500 SW 36th St.

Davie, FL 33314

phone: 954-377-5955

e-mail:mlohmann@usgs.gov

Or visit the Florida Water Science Center Web site at: fl.water.usgs.gov

Prepared by the Raleigh Publishing Service Center Edited by Kay P. Naugle Illustrations by Bonnie J. Turcott Layout by Mike G. Deacon

A PDF version of this publication is available online at http://pubs.usgs.gov/sir/2011/5180 
